\title{
Recent technological and methodological advances for the investigation of landslide dams
}

\author{
Xuanmei Fan ${ }^{\mathrm{a}}$, Anja Dufresne ${ }^{\mathrm{b}, *}$, Jim Whiteley ${ }^{\mathrm{c}, \mathrm{d}}$, Ali P. Yunus ${ }^{\mathrm{a}}$, \\ Srikrishnan Siva Subramanian ${ }^{\mathrm{a}}$, Chukwueloka A.U. Okeke ${ }^{\mathrm{e}}$, Tomáš Pánek ${ }^{\mathrm{f}}$, \\ Reginald L. Hermanns ${ }^{g, h}$, Peng Ming ${ }^{i}$, Alexander Strom ${ }^{j}$, Hans-Balder Havenith ${ }^{k}$, \\ Stuart Dunning ${ }^{1}$, Gonghui Wang ${ }^{\mathrm{m}}$, Carlo Tacconi Stefanelli ${ }^{\mathrm{n}}$ \\ a State Key Laboratory of Geohazard Prevention and Geoenvironment Protection, Chengdu University of Technology, 610059 Chengdu, Sichuan, People's Republic of \\ China \\ ${ }^{\mathrm{b}}$ Engineering Geology and Hydrogeology, RWTH-Aachen University, Lochnerstr. 4-20, 52066 Aachen, Germany \\ ${ }^{\mathrm{c}}$ School of Earth Sciences, University of Bristol, Wills Memorial Building, Queens Road, Bristol BS8 1RJ, United Kingdom \\ ${ }^{\mathrm{d}}$ British Geological Survey, Environmental Science Centre, Nicker Hill, Keyworth, Nottingham NG12 5GG, United Kingdom \\ ${ }^{\mathrm{e}}$ Department of Civil Engineering, College of Engineering, Covenant University Ota, Ogun State, Nigeria \\ ${ }^{\mathrm{f}}$ Department of Physical Geography and Geoecology, University of Ostrava, Chittussiho 10, Slezská Ostrava, Czech Republic \\ ${ }^{g}$ Geohazards and Earth Observation, Geological Survey of Norway, Trondheim N-7491, Norway \\ ${ }^{\mathrm{h}}$ Department of Geoscience and Petroleum, Norwegian University of Science and Technology, Norway \\ ${ }^{i}$ Department of Geotechnical Engineering, Tongji University, Shanghai, China \\ ${ }^{\mathrm{j}}$ Geodynamics Research Centre LLC, $3^{\text {rd }}$ Novomikhalkovsky Passage, 9, 125008 Moscow, Russia \\ ${ }^{\mathrm{k}}$ Department of Geology, Université de Liège, Belgium \\ ${ }^{1}$ School of Geography, Politics and Sociology, Newcastle University, Newcastle upon Tyne NE1 7RU, UK \\ ${ }^{\mathrm{m}}$ Section of Mountain Hazards, Disaster Prevention Research Institute, Kyoto University, Kyoto, Japan \\ ${ }^{n}$ Department of Earth Sciences, University of Firenze, Via La Pira, 4, Florence 50121, Italy
}

\section{A R T I C L E I N F O}

\section{Keywords:}

Landslide dam

Sedimentology

Embankment dam

Hazard mitigation

Geophysics

Numerical modelling

Remote sensing

Dating

Rockslide dam

\begin{abstract}
A B S T R A C T
River-damming by landslides is a widespread phenomenon around the world. Recent advances in remote sensing technology and the rising commercial availability of their products enable the assemblage of increasingly more complete inventories and improve monitoring efforts. On the ground, multi-method dating campaigns enhance our understanding of the timelines of dam formation and failure. In comparison to single-dating methods, they reduce uncertainty by using different materials from the landslide deposit, facilitate the advantages of each method, and consider the deposit and the source area. They can pin dates on the time of lake drainage where backwater sediments are included in the dating campaign and thus inform about dam longevity. Geophysical methods provide non-invasive and rapid methods to investigate the properties and interior conditions of landslide dams. By identifying, e.g. evolving zones of weakness and saturation they can aid in the monitoring of a dam in addition to providing information on interior stratification for scientific research. To verify results from geophysical campaigns, and to add details of dam interior structures and geotechnical properties, knowledge of their sedimentology is essential. This information is gathered at sections from breached dams, other (partially) eroded landslide deposits, and through laboratory testing of sampled material. Combining the knowledge gained from all these methods with insights from blast-fill and embankment dam construction, physical and numerical modelling in multi-disciplinary research projects is the way forward in landslide dam research, assessment and monitoring. This review offers a broad, yet concise overview of the state-of-the-art in the aforementioned research fields. It completes the review of Fan et al. (2020) on the formation and impact on landslide dams.
\end{abstract}

\footnotetext{
* Corresponding author.

E-mail address: dufresne@lih.rwth-aachen.de (A. Dufresne).
} 


\section{Introduction}

Landslide dams are formed by various types of mass movements and are characterized by both complex and composite geomorphological features and geotechnical properties. The challenges of landslide dam research lie in (i) understanding dam failure mechanisms, (ii) analysing internal and external factors for the prediction of their formation and stability under diverse geo-environmental conditions, (iii) assessing their possible short- and long-term hazards and impacts, as well as (iv) risk reduction and management. The dam-lake-systems are complex, resulting from the interactions between the mass movement itself, topographic constraints, and the river and catchment dynamics. Their instantaneous formation and immediate hazards juxtapose the longterm effects they have on the landscape. In the time after immediate hazards are mitigated, any apparent stability of the dam, suggested by the presence of a lake, may distract from secondary or delayed hazards (such as collapse of seemingly stable dams centuries after their formation). Hence, landslide dams form part of a process chain or hazard cascade. The long- and short-term impacts of large landslide dams can only be understood if their timelines are known through dating their formation and failure (Ivy-Ochs et al., 2009; Ivy-Ochs et al., 2017). Furthermore, our improved knowledge of their global distribution and geomorphic characteristics provide a good basis for statistical analyses (cf. Fan et al., 2020) of, e.g. their dimensions and longevities.

Technological developments have improved available data collection tools (e.g. satellites, unmanned aerial vehicles - UAVs), which help identify the large numbers of landslide dams in the aftermath of single, large-scale triggering events, such as the 2008 Wenchuan earthquake (China), the 2015 Gorkha earthquake (Nepal), and the 2016 Kaikoura earthquake (New Zealand) (Casagli et al., 2016; Fan et al., 2012b; Guzzetti et al., 2012; Massey et al., 2018; Scaioni et al., 2014). New research on the interior structure and depositional facies of large landslides helps better understand the relationship of landslide sedimentology to dam stability, such as preferential seepage pathways or processes of overtopping failure. In particular, the failure stages as a function of grain-size changes with depth within the deposit can be better understood by considering depositional facies characteristics and distribution (Dufresne et al., 2016; Dunning and Armitage, 2011; Weidinger et al., 2014). Recent studies bring together the experiences gained from geophysical investigations, identifying the opportunities and limitations of the different methods (Wang et al., 2016a; Wang et al., 2016c; Wang, 2008). Likewise, although small-scale field and laboratory models are mainly designed for artificial dams, a lot can be gleaned from their performance to better understand failure mechanisms of natural blockages. Finally, the growing number of computer programs and numerical modelling tools-ranging from simple to robust approaches-can increasingly handle the modelling of geomorphic processes starting from dam formation, its projected stability, breach, and potential breach-induced flooding (Fan et al., 2019c).

With these recent developments in laboratory-scale geotechnical testing systems, geological and geophysical investigation tools, remote sensing technology and availability, combinations of age-dating methods, and new numerical modelling techniques, scientists seek solutions to overcome the challenges involved in landslide-dam assessment. This review is a continuation of our paper on the formation and impacts of landslide dams (Fan et al., 2020). Herein, we present the technological and methodological advances in landslide dam research over the past decades.

\section{Recent advances in landslide dam investigations}

This section is a review of the state-of-the-art in (2.1.) remote sensing, (2.2.) dating, (2.3.) geophysical methods, and (2.4.) sedimentology and geotechnical properties of landslide dam research. With remote sensing techniques, landslide deposits are identified on much larger scales than previously possible. Consequently, the number of identified landslide dams in inventories and databases increases, providing statistically significant data for analyses of spatial distribution and dam dimensions. Dating then sets this spatial data into temporal context, and allows expanding frequency analyses of river-blocking events from historical inventories into the geological past. It can furthermore inform about the longevity of individual dams by including associated sediments into dating campaigns. Geophysical investigations deliver insights into the internal structure of intact dams, and sedimentological analyses of breached dams (or other, partially eroded landslide deposits) add knowledge on the associated geotechnical properties - both vital for understanding the processes involved and the properties relevant in dam stability analyses.

\subsection{Remote sensing}

Remote sensing techniques and sensors have undergone considerable technological progress and have become powerful tools for many aspects of landslide (dam) identification and investigation in recent years (Ermini et al., 2006; Fan et al., 2013; Scaioni et al., 2014) as resolution, accuracy, acquisition time, logistics (sensor dimensions), and availability keep improving.

\subsubsection{Landslide dam inventories}

Historical aerial photographs and optical (Visible-NIR spectrum) satellite images are typically employed for the creation of dam inventories (e.g. Emmer et al., 2016; Korup, 2005). Recently, free web services, such as Google EarthPro ${ }^{\circledR}$ or Bing Maps ${ }^{\mathrm{TM}}$, which provide 3D models and image archives, are also used for landslide-dam recognition and the creation of inventories (Strom and Abdrakhmatov, 2018; Tacconi Stefanelli et al., 2015; Tacconi Stefanelli et al., 2018). Optical image interpretation is particularly useful in post-event reconstruction (Fan et al., 2009; Yamazaki and Matsuoka, 2007), since the differences between mobilized material and the unaffected areas are usually evident. Most commonly, dam inventories are created through visual interpretation of landslide source and deposition zones by comparing pre- and post-event false-color composites or panchromatic images. For example, Fan et al. (2012b) created an inventory comprising 828 landslide dams induced by the 2008 Wenchuan earthquake in China by visual interpretation of ASTER, ALOS AVNIR-2, ALOS PRISM, Cartosat1, SPOT-5, and IKONOS data.

Older landslides are more difficult to identify from imagery. In such cases, dam inventory mapping may involve detecting the dammed lake

Table 1

Automated water extraction indices based on remote sensing that are used in lake (water) body identification.

\begin{tabular}{|c|c|c|}
\hline Index & Formula & Reference \\
\hline Normalized difference water index (NDWI) & Green - Near InfraRed & McFeeters (1996) \\
\hline Modified normalized difference water index (MNDWI) & $\begin{array}{l}\text { NDWI }=\overline{\text { Green }+ \text { Near InfraRed }} \\
M N D W I=\frac{\text { Green }- \text { SWIR } 1}{\text { Green }+ \text { SWIR } 1}\end{array}$ & Han-Qiu (2005) \\
\hline Automated water extraction index (AWEI) & $A W E I=4 \times($ Green $-S W I R 1)-(0.25 \times N I R+2.75 \times S W I R 2)$ & Feyisa et al. (2014) \\
\hline Tasseled Cap Wetness (TCW) & $T C W=0.0315$ Blue +0.2021 Green +0.3102 Red +0.1594 NIR -0.6806 SWIR $1-0.6109$ SWIR 2 & Crist (1985) \\
\hline Water Index (WI) & $W I=1.7204+171$ Green +3 Red -70 NIR -45 SWIR $1-71$ SWIR 2 & Fisher et al. (2016) \\
\hline
\end{tabular}


instead (e.g. Emmer et al., 2016). This is because water bodies can be highlighted easily in remote sensing images using various spectral indices and transformations (Feyisa et al., 2014; McFeeters, 1996); Table 1. However, in the initial stage of dam formation, lake extents are difficult to distinguish unless the inflow is sufficiently high. Also, many landslide dams fail shortly after formation and the lakes are drained. Despite significant progress in automatic or semi-automatic detection of landslides (e.g. Smith et al., 2020), visual interpretation of landforms is still an efficient and reliable method for compiling regional inventories of landslide dams, as well as for inventories of large landslides themselves (e.g. Strom and Abdrakhmatov, 2018). The most effective method is a combination of remote sensing data with site investigations, especially in forested areas and in narrow valleys where steep slopes mask large parts of an image by shadows or disadvantageous satellite line-ofsight.

For locating breached dams, Safran et al. (2015) suggest (i) looking for landslide deposits on either side of the river, (ii) checking for highly constricted and/or laterally displaced river reaches, (iii) locating
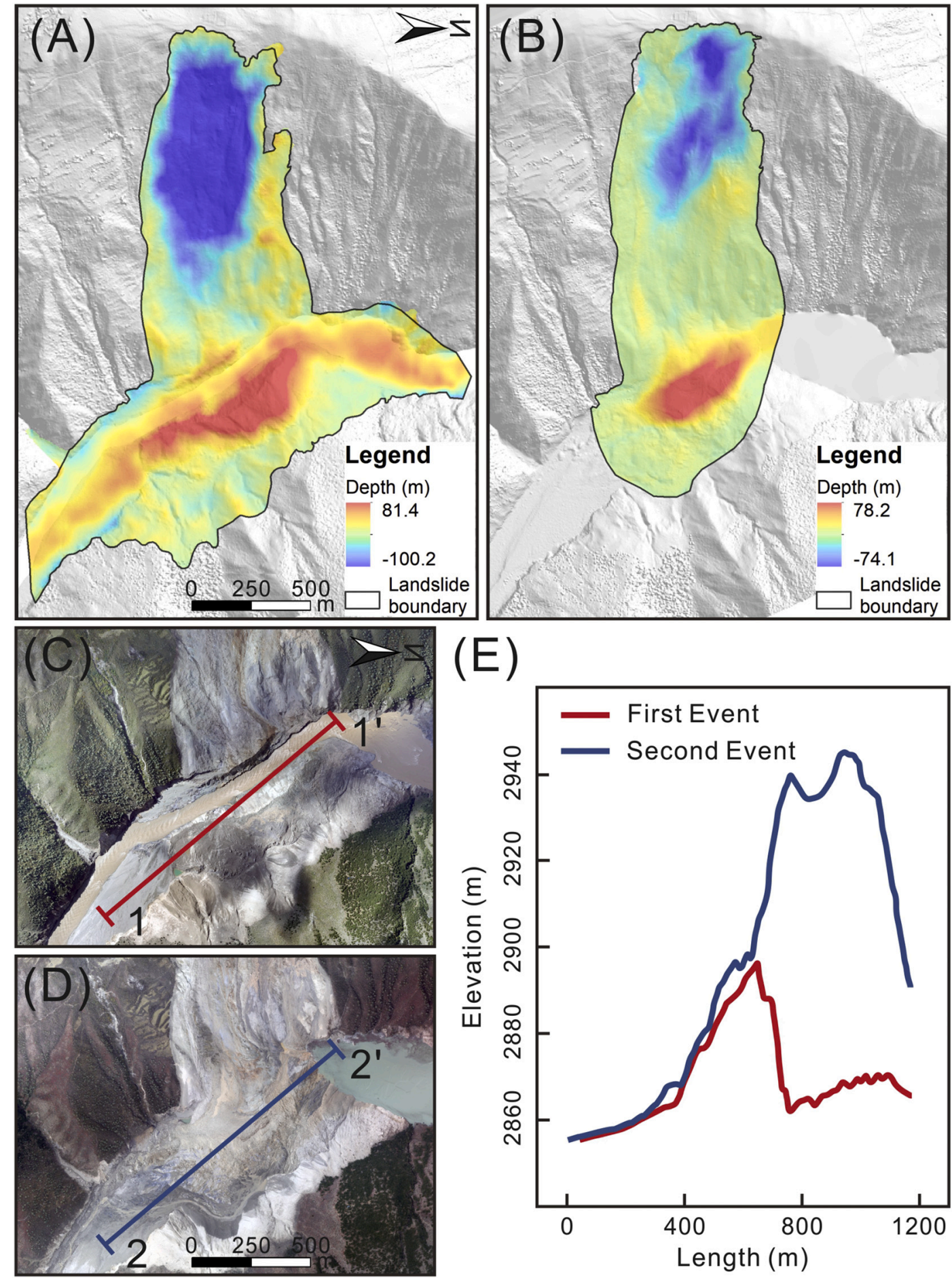

(E)

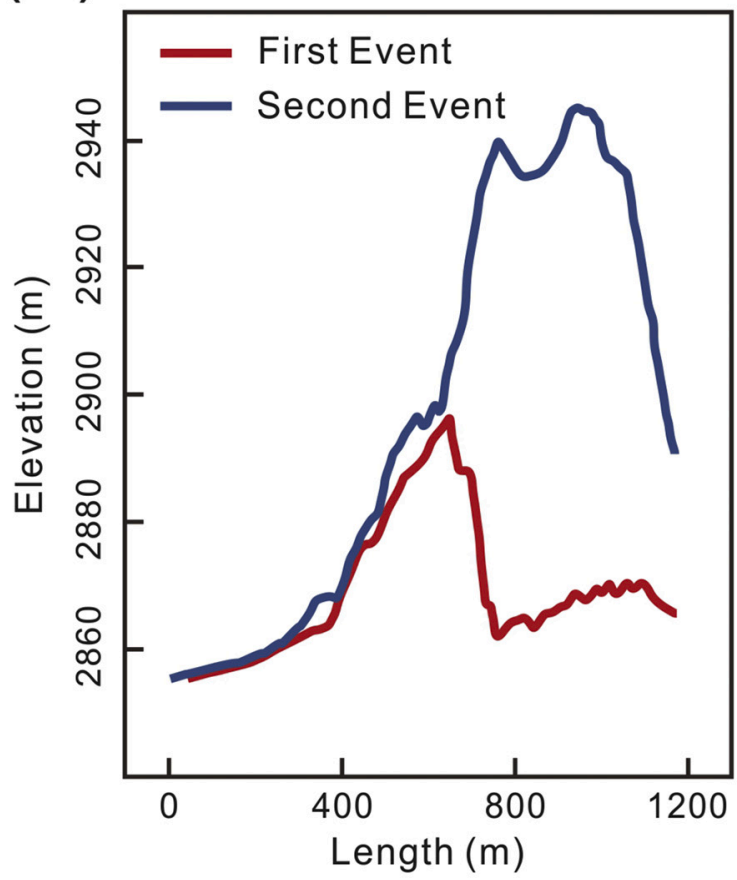

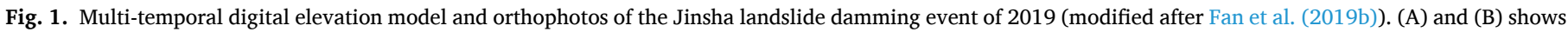

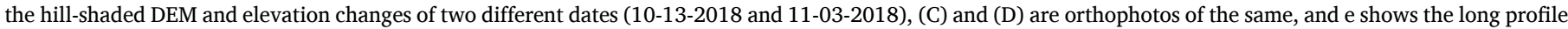
A-A' and B-B' given in (C) and (D). 
knickpoints/rapids, (iv) identifying terraces, since they suggest sediment accumulation within the impoundment, and (v) looking for outburst deposits in the river channel. Implementing these suggestions is possible with high-resolution images and digital elevation models, including Google Earth ${ }^{\circledR}$ imagery, aerial photos, and LiDAR (Light Detection and Ranging - a surveying method that measures distances using a laser) digital elevation models (DEMs).

\subsubsection{Dam and lake geometry mapping}

Landsat, SPOT, and ASTER optical images have significant historical archives, and together with global DEMs, are the most utilized remotesensing data for estimating the geometry of landslide dams, water surface elevations, and lake areas and volumes (e.g. Delaney and Evans, 2015; Delaney and Evans, 2017; Parvaiz et al., 2012). Global coverage (1-3 arc-seconds) SRTM DEM, developed from single-pass interferometry of C-Band radar, and ASTER Global DEM generated from stereopairs of optical images are available since the last 10-20 years. In terms of accuracy, these datasets can provide satisfactory first-order topographic characterization (Delaney and Evans, 2017) of larger features. The basic geometric characteristics measured from DEMs and imageries include dam height $(\mathrm{H})$, transverse (cross-river) length $(\mathrm{L})$, longitudinal (along-river) width (W), the volume of the landslide dam $\left(\mathrm{V}_{d}\right)$, area of the lake $\left(\mathrm{A}_{l}\right)$, perimeter of the lake $\left(\mathrm{P}_{l}\right)$, and the lake storage volume $\left(\mathrm{V}_{l}\right)$.

Since 2015, global SRTM DEM is available at 1-arc-second resolution, with only 3 -arc-second data available prior to this (except in the United States). For historical cases, archived aerial photos are best suited (Tacconi Stefanelli et al., 2018). Declassified Corona satellite imagery (U.S. satellites 1960-1972) were also assessed in some historical cases (Shroder Jr and Weihs, 2010). Dimensions of individual landslide dams can also be determined by Unmanned Aerial Vehicle (UAV) platforms (Fan et al., 2019b; Wallace et al., 2012). UAV (also termed UAS - Unmanned Aerial Systems or simply drones) images and structure-frommotion (SfM) photogrammetric techniques for developing DEMs are gaining popularity owing to their low cost, high resolution, and rapid deployment (Fig. 1).

Using SRTM data, Tacconi Stefanelli et al. (2018) detailed the geometry of 51 landslide dams in the Cordillera Blanca, Peru. Delaney and Evans (2015) used optical images together with DEM to determine the shoreline and lake volume formed by the 2000 Yigong rockslidedammed lake, Tibetan Plateau. They later developed a pixel-by-pixel technique following Leblanc et al. (2006) and others (Dong et al., 2014; Dong et al., 2011b) to obtain mean pool height of the lake and applied it to Lake Gojal, a 2010 rockslide-dammed lake formed in the Hunza River, Pakistan. Where pre-slide topography is absent, the dam height can be estimated by creating a longitudinal profile of the river extending far downstream and upstream to reconstruct the initial stream level prior to damming, also providing estimates of the initial lake depth and volume. However, in mountainous regions with extremely rugged terrain, spatial resolution of 1-3 arc seconds DEMs is insufficient for creating such profiles.

The technological advances in remote sensing instruments have improved the spatial resolution in topographic measurements through developments such as LiDAR sensors. The laser sensor can be placed on aerial (ALS - Airborne Laser Scannering) or ground platforms (TLS Terrestrial Laser Scanning). ALS tends to cover a wide area at moderate resolution (1-10 m), whereas TLS is better suited for local-scale surveys at higher resolution (about $1 \mathrm{~cm}$ to $1 \mathrm{~m}$ ). Post-processing of LiDAR surveys can filter vegetation coverage and model the terrain surface in densely forested areas (e.g. Eeckhaut et al., 2007; Görüm, 2019; Jaboyedoff et al., 2012).

\subsubsection{Monitoring dam deformation}

Deformation analysis of landslide dams requires interpretation of coregistered optical images taken at different times in order to compare equivalent areas (Barazzetti et al., 2014). Multi-temporal photogrammetric techniques allow quantitative comparison of DEMs and the evaluation of volume changes (Lucieer, and Jong, S.M.d., Turner, D., 2014; Peternel et al., 2017). UAV platforms are well-suited to this purpose as they can easily provide multi-temporal, high-resolution images at short time intervals. In general, landslide dam monitoring using optical images has two main drawbacks: the strong dependency on meteorological and light conditions, and the potential presence of vegetation that limit photogrammetric techniques.

In adverse climatic conditions, repeat pass satellite imagery utilizes Synthetic Aperture Radar (SAR), a powerful tool for measuring surface deformation of unstable slopes over large regions (Rott and Siegel, 1999; Tofani et al., 2010). SAR is an active radar sensor system (i.e. not affected by cloud coverage or light conditions) that can be installed on spaceborne, airborne and ground-based platforms. It registers the backscattered echo from the target surface in amplitude and phase image maps.

Interferometric Synthetic Aperture Radar (InSAR), which analyses the phase difference between two images of the same area at different times, has proved to be an extremely powerful tool for measuring terrain displacement (Massonnet and Feigl, 1998; Raspini et al., 2017; Walter et al., 2020). Several subsequent methodologies have been developed (e. g. DInSAR and Multi-Temporal Interferometry) in order to remove errors due to temporal and geometric decorrelation (Colesanti et al., 2003; Crosetto et al., 2005; Raspini et al., 2017; Rott and Siegel, 1999; Wasowski and Bovenga, 2014). Permanent Scatterer Interferometry (PSI) (Ferretti et al., 2001), measuring millimetric movements of natural reflectors with coherent backscatter over time (i.e. rock outcrops or infrastructure, but not vegetated areas), has become popular in landslide identification and monitoring (e.g. Tofani et al., 2010). Satellite or Sbased InSAR is suitable for monitoring slow-moving landslides and apparently stable landslide dams, and could also be used to detect precursory movements to sliding failure (Intrieri et al., 2018). The main drawbacks of these spaceborne techniques are related to the sensor (phase and temporal resolution) and the topography (visibility in steep mountain terrains). Ground-based SAR (GBSAR) overcomes many of the drawbacks of the satellite platform by drastically reducing the repeat time (up to few minutes) and allowing choice of the line-of-sight (LOS), although vegetation cover, and transport and logistics issues can still limit this method. While deformation of slow-deforming landslide dams can be analyzed using InSAR techniques, one major limitation is their inability to measure large spatial gradients of rapid deformation. The sub-pixel offset tracking (SPOT) method can be an alternate, though less precise than conventional InSAR methods, this technique can overcome the limitation on the spatial displacement gradient and are far more robust (Singleton et al., 2014; Sun and Muller, 2016).

LiDAR sensors are also used in landslide monitoring and post-event analysis, providing multi-temporal high-resolution DEMs to obtain positive and negative volumetric changes between data sets (Corsini et al., 2009; Pesci et al., 2011). After the 2016 Kaikoura (New Zealand) earthquake, Massey et al. (2018) used airborne LiDAR data for sitespecific landslide dam surveys and assessments.

\subsubsection{Summary and outlook}

Increases in spatial resolution ( $\sim$ few meters), reductions in revisit periods (up to one day) of the latest addition of satellites (e.g. SENTINEL-2, Pleiades-HR, PlanetScope constellations, etc.), and open cloud platforms (e.g. Google Earth Engine) make them increasingly useful for landslide inventory mapping. For example, PlanetScope constellations, with 120 satellites currently in orbit, offer a revisit time of one day and imageries at $\sim 3$-m-resolution in four wavelengths (red, green, blue, and near-infrared), which is a game changer in rapid disaster mapping. Optical imageries, however, suffer from dependency on meteorological factors (cloud cover) in adverse weather conditions, usually associated with rainfall-induced natural hazards. Although spaceborne microwave sensors overcome this issue, the data require significant preprocessing. Some of these microwave sensors are on-par 
with optical imageries in terms of spatial and temporal resolutions. For instance, the COSMO-SkyMed system, with a constellation of four satellites offers very high revisit frequency and resolution up to $1 \mathrm{~m}$ in spotlight mode.

In data-sparse regions, dam geometric mapping still relies upon SRTM DEM or ASTER GDEM. These two datasets have vertical accuracy of $\sim 16 \mathrm{~m}$ and $\sim 17 \mathrm{~m}$, respectively (Farr et al., 2007; Tachikawa et al., 2011; Yunus et al., 2016). Promising improvements in terms of vertical accuracies by eliminating major error components from existing DEMs may be helpful in future studies. For example, the MERIT DEM was developed by removing multiple error components from SRTM3 v2.1 and AW3D-30m v1 (Yamazaki et al., 2017). This DEM represents the terrain elevations at 3-arc-second resolution and covers almost the entire globe. However, for data-rich regions, obtaining accurate geometrical parameters of landslides and landslide dams is relatively easy. The Geospatial Authority of Japan, for example, provides nationwide 5-m airborne LiDAR DEM with vertical accuracy of $\sim 1 \mathrm{~m}$ (Avtar et al., 2015).

A cheap alternative in data-sparse regions is employment of optical photogrammetry using UAVs to obtain 3D models. The rapid advancement of UAV systems in terms of cost, miniaturization and flying time means they are becoming indispensable tools in landslide-dam mapping. However, at present the flying time for a low-to-medium-cost UAV (e.g., DJI Phantom 4) is limited to 20-30 minutes with a one- or two-battery power supply; and they can only fly to a limited height, restricting the coverage of large areas of interest. The development of professional drones for scientific use and the reductions of sensor dimensions promises to overcome current UAV limitations (Rossi et al., 2018). Commercially available TanDEM-X data (DEM at $\sim 10$ m resolution, $\sim 4$ $\mathrm{m}$ vertical accuracy) may be a viable alternative, but there exist gaps in spatial coverage, especially for steep mountainous terrains. With more orbital passes in future, TanDEM-X missions are expected to reduce this limitation.

\subsection{Dating timelines of dam formation and failure}

In historical inventories, the spatial distribution, time of formation and, in cases with sufficiently long observation times, the years of stability are well-constrained (cf. Fan et al., 2020 for list of world-wide inventories). Whereas the same spatial analysis tools apply for prehistoric events, the timeline of dam formation and failure is poorly, or not at all, constrained. To date, only 220 landslide dams have been dated in the world (Fig. 2A), and yet, the correct determination of a landslide dam's age is vital for understanding the longevity as well as the frequency of river damming. Therefore, we focus on this gap in knowledge, summarize available dating methods, and underline the value of better age constraints.

Dating of landslides is a broad topic, and review papers exist that we recommend to the interested reader (Lang et al., 1999; Pánek, 2015). In the following, we focus on work done on dating landslide dams as well as new developments that are promising applications for this particular phenomenon. The methods of dating landslide dams are described in Table 2 and their application to specific datable landslide features is shown in Fig. 3. Although a broad range of dating methods exists, only some of them have become widely used (Fig. 2b), which we review in the following paragraphs.

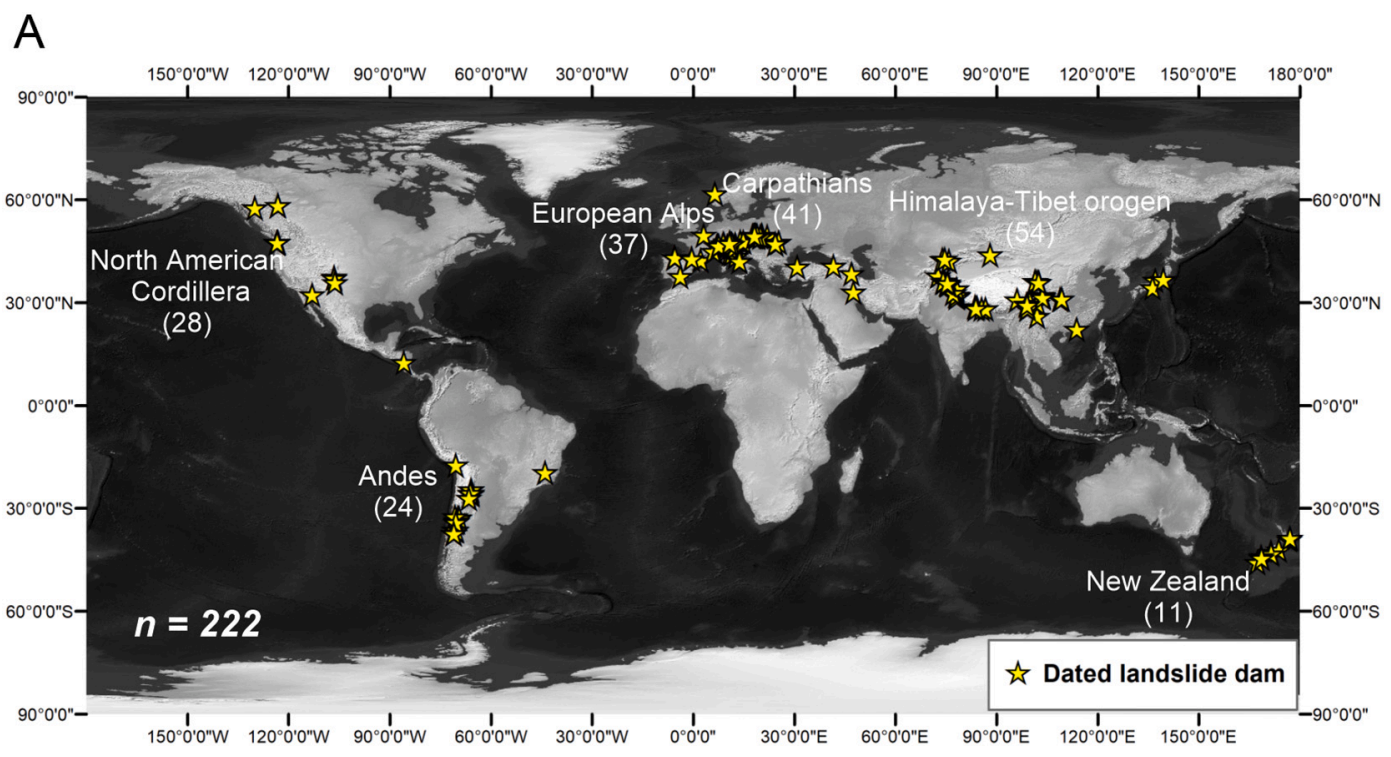

B

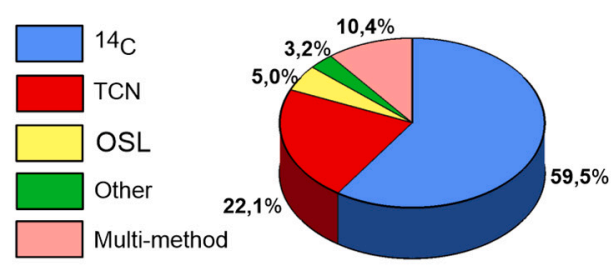

C

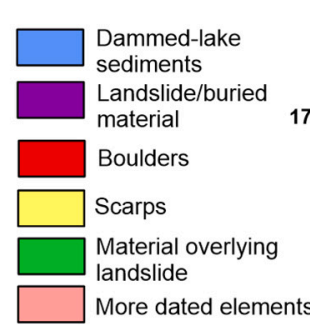

Dated feature

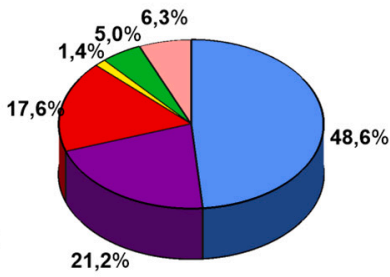

Fig. 2. (A) Worldwide distribution of dated landslide dams $(\mathrm{n}=222)$. Numbers inside brackets are the total number of dated landslide dams in selected regions. (B) and (C) display the proportion of individual methods and landslide features respectively used for the landslide-dam age determination. 
Table 2

Methods applicable for dating of landslide dams.

\begin{tabular}{|c|c|c|c|c|c|}
\hline Dating method & $\begin{array}{l}\text { Useful time } \\
\text { range }\end{array}$ & $\begin{array}{l}\text { Dated landslide materials } \\
\text { and features }\end{array}$ & Advantage & Limits & Examples of references \\
\hline Radiocarbon ${ }^{14} \mathrm{C}$ & $\sim 0.2-50 \mathrm{ka}$ & $\begin{array}{l}\text { Organics incorporated or } \\
\text { buried by landslide; } \\
\text { dammed-lake deposits; } \\
\text { trees drowned in dammed } \\
\text { lakes }\end{array}$ & $\begin{array}{l}\text { High precision of dating; } \\
\text { abundance of organic } \\
\text { material within dammed- } \\
\text { lake deposits }\end{array}$ & $\begin{array}{l}\text { Lack of organics incorporated } \\
\text { within landslide material; risk of } \\
\text { inaccurate dating results of } \\
\text { dammed deposits due to hard } \\
\text { water effects; does not date } \\
\text { impoundment but lake phase that } \\
\text { can last thousands of years. }\end{array}$ & $\begin{array}{l}\text { Adams (1981); Geertsema and } \\
\text { Clague (2006); Nicolussi et al. } \\
\text { (2015); Reneau and Dethier } \\
\text { (1996); Schuster et al. (1992) }\end{array}$ \\
\hline $\begin{array}{l}\mathrm{TCN}^{1}\left({ }^{10} \mathrm{Be},{ }^{26} \mathrm{Al},{ }^{36} \mathrm{Cl},\right. \\
\left.{ }^{21} \mathrm{Ne},{ }^{3} \mathrm{He}\right)\end{array}$ & 0 - several Ma & $\begin{array}{l}\text { Exposed landslide scarps or } \\
\text { boulders }\end{array}$ & $\begin{array}{l}\text { Relatively ubiquitous } \\
\text { datable landslide features; } \\
\text { target minerals common in } \\
\text { rocks; dates the } \\
\text { impoundment event. }\end{array}$ & $\begin{array}{l}\text { Possible errors of dating related to } \\
\text { unknown pre-exposure } \\
\text { inheritance; rejuvenation of } \\
\text { exposure ages due to erosion and } \\
\text { tilting }\end{array}$ & $\begin{array}{l}\text { Castleton et al. (2016); Delgado } \\
\text { et al. (2020); Hermanns et al. } \\
\text { (2004); Hermanns et al. (2015); } \\
\text { Hermanns et al. (2017); Hewitt } \\
\text { et al. (2011); Ivy-Ochs et al. } \\
\text { (2009); Ivy-Ochs et al. (2017); } \\
\text { Prager et al. (2009); Sanhueza- } \\
\text { Pino et al. (2011); Schleier et al. } \\
\text { (2015); Schleier et al. (2017) }\end{array}$ \\
\hline $\begin{array}{l}\text { Luminescence } \text { OSL }^{2} \text {, } \\
\mathrm{TL}^{3}, \mathrm{IRSL}^{4}, \mathrm{TT}- \\
\left.\mathrm{OSL}^{5}\right)\end{array}$ & $\begin{array}{l}<300 \mathrm{ka} \\
\text { (up to } 1 \mathrm{Ma} \text { in } \\
\text { case of TT-OSL) }\end{array}$ & $\begin{array}{l}\text { Dammed-lake deposits; } \\
\text { alluvial or aeolian deposits } \\
\text { on the surface of landslides } \\
\text { or buried by landslide } \\
\text { debris }\end{array}$ & $\begin{array}{l}\text { Datable materials are } \\
\text { ubiquitous; replaces }{ }^{14} \mathrm{C} \text { in } \\
\text { the absence of organics }\end{array}$ & $\begin{array}{l}\text { Insufficient bleaching of grains } \\
\text { during some types of transport (e. } \\
\text { g. fluvial); lower precision of } \\
\text { dating. Dates stratigraphically } \\
\text { related sediments but not the } \\
\text { impoundment. }\end{array}$ & $\begin{array}{l}\text { Bao et al. (2020); Chen et al. } \\
\text { (2018); Guerrero et al. (2018); } \\
\text { Lee and Dai (2011); Zhang et al. } \\
\text { (2019b) }\end{array}$ \\
\hline U-series $\left({ }^{234} \mathrm{U} /{ }^{230} \mathrm{Th}\right)$ & $<350 \mathrm{ka}$ & $\begin{array}{l}\text { Secondary speleothems or } \\
\text { calcite cement infilling } \\
\text { voids within landslide } \\
\text { material }\end{array}$ & $\begin{array}{l}\text { Datable materials are } \\
\text { ubiquitous in limestone } \\
\text { terrains; might replaces }{ }^{14} \mathrm{C} \\
\text { in the absence of organics }\end{array}$ & $\begin{array}{l}\text { Lack of datable materials in non- } \\
\text { carbonate terrains; presence of } \\
\text { detrital Th cause departure from } \\
\text { closed-system behaviour and lead } \\
\text { to inaccurate dating results; post- } \\
\text { dates the impoundment. }\end{array}$ & $\begin{array}{l}\text { Ostermann et al. (2017); } \\
\text { Ostermann and Sanders (2017) }\end{array}$ \\
\hline $\begin{array}{l}\text { Short-lived } \\
\text { radioactive isotopes } \\
\left({ }^{210} \mathrm{~Pb},{ }^{137} \mathrm{Cs}\right)\end{array}$ & $\begin{array}{l}\text { Several decades } \\
(\sim 150 \text { years in } \\
\left.\text { case of }{ }^{210} \mathrm{~Pb}\right)\end{array}$ & Dammed-lake deposits & High precision of dating & Extremely short time range & Pánek et al. (2013) \\
\hline $\begin{array}{l}\text { Tephrochronology, } \\
{ }^{40} \mathrm{Ar} /{ }^{39} \mathrm{Ar}\end{array}$ & 0 - several Ma & $\begin{array}{l}\text { Tephras or lava flows } \\
\text { overlying or underlying } \\
\text { landslides; tephras } \\
\text { accumulated in the } \\
\text { dammed lakes, tephra in } \\
\text { ponds on the landslide }\end{array}$ & $\begin{array}{l}\text { Long time-range, } \\
\text { possibility of tracing tephra } \\
\text { layers over extensive areas }\end{array}$ & $\begin{array}{l}\text { Absence of datable materials in } \\
\text { non-volcanic terrains; dates } \\
\text { stratigraphically related deposits } \\
\text { or the lake phase that can last for } \\
\text { thousands of years. }\end{array}$ & $\begin{array}{l}\text { Beetham et al. (2002); } \\
\text { Hermanns and Schellenberger } \\
\text { (2008); Hermanns and } \\
\text { Niedermann (2011); Thouret } \\
\text { et al. (2017) }\end{array}$ \\
\hline $\begin{array}{l}\text { Dendrochronology - } \\
\text { dead trees }\end{array}$ & $\begin{array}{l}0 \text { - several ka } \\
\text { (dependent on } \\
\text { existing local } \\
\text { master } \\
\text { chronology }\end{array}$ & $\begin{array}{l}\text { Tree trunks buried by } \\
\text { landslide; trees drowned in } \\
\text { dammed lakes etc. }\end{array}$ & $\begin{array}{l}\text { High precision; possible } \\
\text { wiggle-matching analysis } \\
\text { with }{ }^{14} \mathrm{C} \text { dated trunks; } \\
\text { possibility of inferring } \\
\text { climatic conditions during } \\
\text { landslide origin }\end{array}$ & $\begin{array}{l}\text { Lack of available opportunities for } \\
\text { dating }\end{array}$ & $\begin{array}{l}\text { Nicolussi et al. (2015); Yamada } \\
\text { et al. (2018) }\end{array}$ \\
\hline $\begin{array}{l}\text { Dendrochronology - } \\
\text { living trees }\end{array}$ & $\begin{array}{l}0-\text { several } \\
\text { hundreds of } \\
\text { years }\end{array}$ & $\begin{array}{l}\text { Tree cohorts growing on } \\
\text { landslide bodies }\end{array}$ & $\begin{array}{l}\text { Datable material is } \\
\text { ubiquitous }\end{array}$ & $\begin{array}{l}\text { Short time range - applicable only } \\
\text { for young dams in pristine } \\
\text { landscapes (not controlled by } \\
\text { forest management); only rough } \\
\text { estimate of landslide dam } \\
\text { minimum age }\end{array}$ & $\begin{array}{l}\text { Not applied for damming } \\
\text { landslides }\end{array}$ \\
\hline Lichenometry & $\begin{array}{l}0-\text { several } \\
\text { hundreds of } \\
\text { years (up to ca. } \\
1,000 \text { years) }\end{array}$ & $\begin{array}{l}\text { Lichens growing on } \\
\text { landslide scarps or } \\
\text { boulders within } \\
\text { accumulations of } \\
\text { landslides }\end{array}$ & $\begin{array}{l}\text { High precision; datable } \\
\text { material is ubiquitous }\end{array}$ & $\begin{array}{l}\text { Short time range: could } \\
\text { underestimate real age. }\end{array}$ & $\begin{array}{l}\text { Belousov (1994); Nikonov and } \\
\text { Shebalina (1979) }\end{array}$ \\
\hline Varve chronology & Floating & Varved lake deposits & High precision & $\begin{array}{l}\text { Dating of the length of the lake } \\
\text { phase }\end{array}$ & $\begin{array}{l}\text { Trauth and Strecker (1999); } \\
\text { Trauth et al. (2000) }\end{array}$ \\
\hline
\end{tabular}

${ }^{1}$ Terrestrial Cosmogenic Nuclide dating; ${ }^{2}$ Optically Stimulated Luminescence; ${ }^{3}$ Thermoluminescence; ${ }^{4}$ Infrared Stimulated Luminescence; ${ }^{5}$ Thermally TransferredOptically Stimulated Luminescence

\subsubsection{Indirect methods: dating lake sediments}

Dating lacustrine sediments with ${ }^{14} \mathrm{C}$ has long been the most-used dating method to assign ages to landslide dams, accounting for $\sim 50 \%$ of dated cases so far (e.g. Abele, 1974; Adams, 1981; Hermanns et al., 2012; Schuster et al., 1992; Trauth and Strecker, 1999). However, this method only provides minimum ages, as it dates sediments that were deposited after river damming by the landslide and ensuing sediment accumulation in the impoundment (with the exception of drowned trees within the lakes) (Schuster et al., 1992). The stratigraphic relations between the landslide sediments and the lake sediments are not always clear. Often, the only relation of the lake sediments to the landslide sediments is that they occur upriver of the dam; they may not even be in direct contact with the landslide body. This poorly-constrained relationship can further limit the use of ${ }^{14} \mathrm{C}$ dating. Multiple landsliding phases forming a single dam are also rarely detectable. Besides, the method is vulnerable to internal errors, such as the 'hard water effect' that allows dead carbon from the substrate to be incorporated into the organic material that lived within the lake, introducing inaccuracies in dating the organic carbon.

Another technique for dating lake sediments is Optically Stimulated Luminescence (OSL). This method determines the last time of daylight exposure of quartz or feldspar grains (cf. Preusser et al., 2008). Accurate dating results rely on the presumption that all grains are 'reset' during pre-deposition transport. This means that enough residence times in 


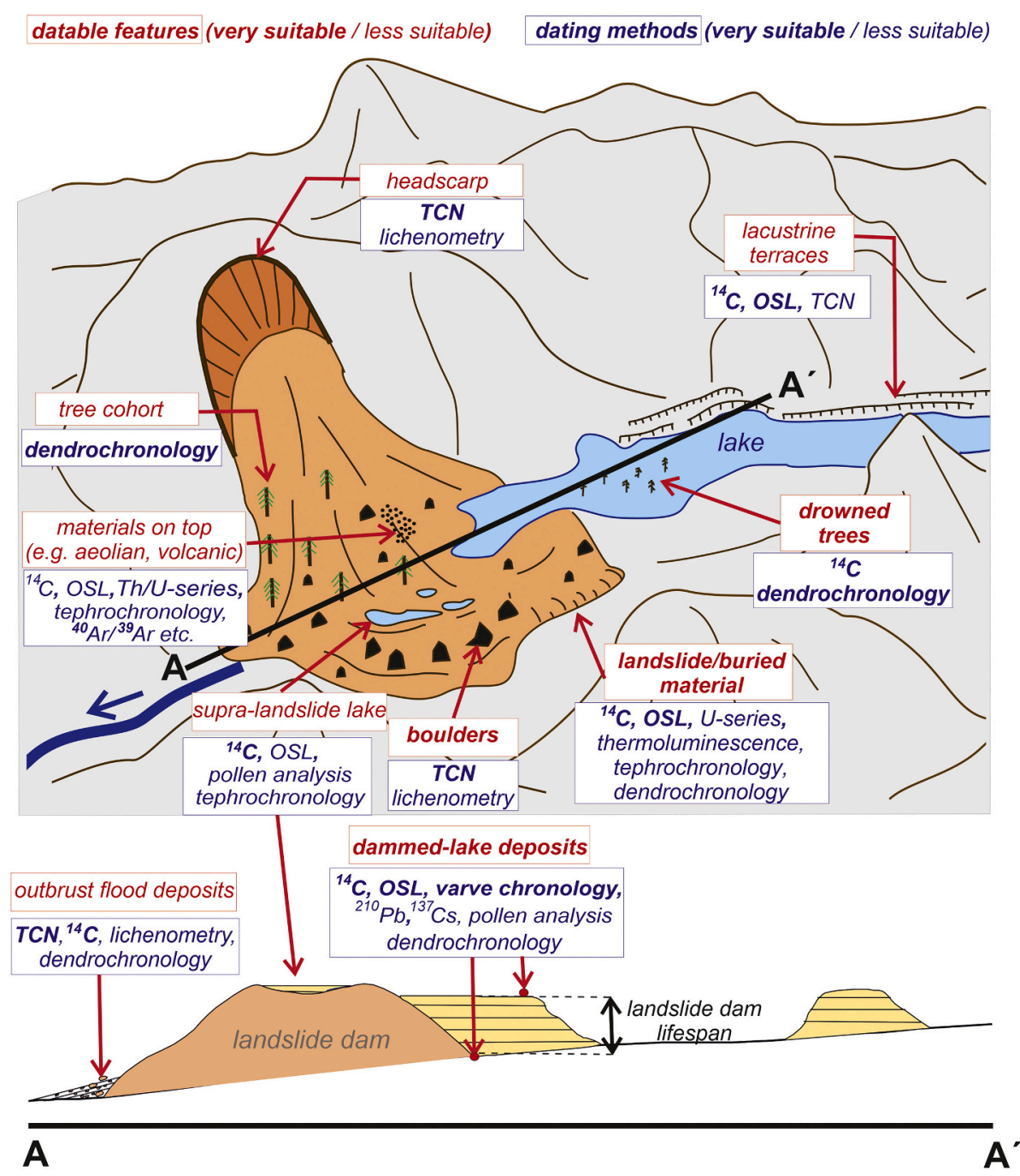

Fig. 3. Datable features and materials with potential for the landslide dam age determination.

river waters from source to sink are needed to ensure sufficient exposure and resetting of the signal prior to burial in the lake sediments. As landslide material is not exposed to solar radiation for long periods, the method is limited to the backwater sediments, and has therefore not been used to date many landslide dams ( $\sim 5 \%$ of dated cases; Fig. $2 \mathrm{~B}$ ). Although the presumption that minerals experience sufficient exposure during transport might be problematic in high-energy (mountain) fluvial environments, the few attempts to date sediments deposited in lakes dammed by, or forming on, rock-avalanche deposits have delivered ages that are in excellent agreement with independent age controls (e.g. Balescu et al., 2007; Castleton et al., 2016; Dong et al., 2014; Dufresne et al., 2018; Hamilton, 2014; Xu et al., 2015).

\subsubsection{Dating dam material: the current challenge}

A big step forward was achieved through terrestrial cosmogenic nuclide dating (TCN) of landslide material (e.g. Ballantyne et al., 1998; Hermanns et al., 2001). Using TCN, the landslide deposit can be dated directly, and the age revealed is thus independent of stratigraphic relationships. Hermanns et al. (2004) first used the TCN method to distinguish different generations of a landslide dam. Many rockslide dams $(\sim 22 \%)$ are now dated using this method (e.g. Ivy-Ochs et al., 2009; Ivy-Ochs et al., 2017; Penna et al., 2011; Schleier et al., 2017; Yi et al., 2006). However, it has to be used with some caution, since landslides often preserve their stratigraphy during emplacement; in particular large rockslides and rock avalanches (e.g. Abdrakhmatov and
Strom, 2006; Charrière et al., 2015; Dufresne et al., 2016; Geertsema and Clague, 2006; Heim, 1932; Hewitt et al., 2008; Johnson, 1978; Weidinger et al., 2014; Yarnold and Lombard, 1989) leading to inheritance of nuclides produced on the slope prior to failure, which can lead to overestimations in deposition age (Hilger et al., 2019; Ivy-Ochs et al., 2009). One approach is to date the surface exposure of landslide scarps directly (Hermanns et al., 2004; Ivy-Ochs et al., 2009), but this is only applicable to scarps without post-failure erosion of the bedrock surfaces; which is uncommon. Furthermore, scarps might be rejuvenated by younger generations of mass movements, which are not related to the damming events (Delgado et al., 2020). In order to avoid uncertainties, it is recommended to combine dating of the landslide scarp and of the landslide dam material itself (Delgado et al., 2020; Hermanns et al., 2004).

Other absolute dating methods have seldom been applied to landslide dams, despite their applicability to the task. One such method is $\mathrm{Th} / \mathrm{U}$-series dating of calcium precipitates that form within the rockslide body (Prager et al., 2009). These precipitates postdate the failure event, and several samples can be dated within one precipitate, with the innermost sample being closest to the real age. Another very promising method is dendrochronology, which, under ideal conditions, can even yield seasonal precision (Nicolussi et al., 2015; Yamada et al., 2018). For instance, the method of "wiggle matching analysis", which is a combination of tree-ring analysis of trunks found within the landslide body and multiple radiocarbon dating on the same sample material, allows 
precise dating to within a few years, even if the event is several thousand years old (Nicolussi et al., 2015). However, this approach relies on identifying a tree trunk that is preserved in the landslide mass, and exposed by erosional processes, or found in drill cores. Less-used dating methods include tephrochronology (Hermanns et al., 2011a), defining relationships to the marine limit (Hilger et al., 2018), or varve chronology (Trauth et al., 2000, 2001).

\subsubsection{Summary and outlook}

Dating landslide dams is often more complex than initially perceived, as dating requires detailed mapping of the morphology and stratigraphy of the landslide and its related sediments, the availability and precision of geochronological methods, and understanding of the landslide type forming the dam. Some types of mass movements, such as rock avalanches, volcanic mass movements, debris flows or landslides in unconsolidated sediments usually provide more dating opportunities (e. g. Delgado et al., 2020; Geertsema and Clague, 2006; Hermanns et al., 2004; Prager et al., 2009) in comparison to coherent rockslides (Beetham et al., 2002). Although recent progress in geochronological methods allows greater dating precision (i.e., a narrower range of dates) due to lowering of analytical uncertainties (Walker, 2005), the accuracy of dating (i.e. how close a result of dating is to the true age) is mostly limited by the availability of appropriate geological materials and datable landslide features (Lang et al., 1999). Therefore, reliable dating of landslide dams is still largely dependent on chance occurrence of ideal dating conditions.

Besides the traditional use of ${ }^{14} \mathrm{C}$ dating on backwater sediments, recent progress has lead in particular to the direct dating of dam material. Furthermore, more and more multi-method dating campaigns have been applied around the globe to date landslides that caused river blockages (e.g. Dong et al., 2014; Dufresne et al., 2018; Hermanns et al., 2011b; Moreiras et al., 2015; Ostermann et al., 2017; Prager et al., 2009), demonstrating one way in which the weaknesses of individual dating approaches can be overcome.

\subsection{Geophysical methods}

To better understand dam stability, the controlling factors need to be investigated, including the stratigraphy and physical properties of the deposited material (Wahl, 1997; Wahl, 2004). To this end, investigations of the interior of the dam itself are required. Due to the potential transient and unstable nature of dams, these investigations need to be rapid and non-invasive. Geophysical methods are used routinely to characterise and monitor the internal conditions of unstable slopes in analogous landslide environments (Jongmans and Garambois, 2007; McCann and Forster, 1990; Whiteley et al., 2019).

\subsubsection{Overview of existing geophysical methods}

To date, 19 geophysical investigations of 22 landslide dams are published in ISI-listed journals and English-language conference proceedings (Table 3$)$. In just over half the cases, multiple methods $(n=12)$ rather than a single method $(\mathrm{n}=10)$ were implemented. Seismic methods are most common $(n=20)$, followed by geoelectric $(n=15)$ and electromagnetic methods $(n=4)$; Fig. 4 . In the following, we provide a background to these techniques, and discuss the strengths and challenges in using geophysical methods to investigate landslide dams.

\subsubsection{Electromagnetic surveys}

Three types of electromagnetic surveys are used to investigate landslide dams: active electromagnetics (EM), ground penetrating radar (GPR), and magnetotellurics (MT). EM surveys utilize diffuse electromagnetic signals in the 10s of $\mathrm{Hz}$ (super-low EM) to 10 s of $\mathrm{kHz}$ (very-low EM) frequency range (Tezkan, 1999), and measure profiles or surface maps of conductivity. Spatial heterogeneities in conductivity may indicate differences in material composition, grain size or saturation (e.g. Santamarina et al., 2005).
GPR surveys generate wave-like signals at higher frequencies, typically a few MHz (high EM) to a few GHz (super-high EM) range (Olhoeft, 2002). Frequency primarily controls depth of penetration; larger wavelengths penetrate further, but cannot resolve small features. Conversely, shorter wavelengths have lower depth penetration, but can resolve smaller features. GPR measurements can assess the water content of materials (e.g. Garambois et al., 2002), but are more commonly used to produce cross-sections identifying structural discontinuities, such as depth to bedrock, stratigraphy and geomorphological features (e.g. Davis and Annan, 1989).

The MT method (Cagniard, 1953) is a passive technique, utilizing a range of frequencies from $<1 \mathrm{~Hz}$ to $10 \mathrm{~s}$ of $\mathrm{kHz}$ (Strangway, 1983), with higher frequencies being typically used for shallow investigations (Strangway et al., 1973). MT measures 1D soundings or 2D profiles of resistivity (the inverse of conductivity), and is sensitive to material composition, grain size and saturation.

\subsubsection{Geoelectric surveys}

Two types of geoelectric survey are used in landslide dam investigations: electrical resistivity tomography (ERT) and self-potential (SP). In an ERT survey, a DC current is injected between a pair of electrodes, and the potential difference is measured between a separate pair (Griffiths and Barker, 1993). Expanding the spacing between the electrodes around a fixed mid-point increases the depth of the measurement, and produces a 1D vertical electrical sounding (VES) beneath the mid-point. The maximum depth of investigation is proportionally restricted to the available ground surface on which electrodes can be deployed. To acquire 2D or 3D ERT data, an array of electrodes is positioned and combinations of injection and potential electrodes at different locations and spacing produce cross-sections or volumes of resistivity (Loke et al., 2013). Inverted resistivity tomograms show variations in geology, hydrology, and engineering properties (e.g. Chambers et al., 2006; Perrone et al., 2014).

The SP method uses a single pair of electrodes to measure spontaneously occurring charges in the subsurface which arise from streaming potentials along with thermokinetic potentials and cultural activity (Patella, 1997). The method is primarily used to identify zones of fluid flow (e.g. Colangelo et al., 2006). The depth of investigation is related to the separation between the electrodes, with the measured self-potential field influenced by the subsurface features present between and beneath the electrodes.

\subsubsection{Seismic surveys}

Elastic waves can be artificially generated for 2D seismic profiling of the subsurface; compressional P-waves (measuring P-wave velocity) and transverse S-waves (measuring S- or shear-wave velocity) are used for seismic refraction tomography (SRT) surveys (Redpath, 1973). SRT measures the travel time of elastic waves as they propagate from a source to seismic receivers (i.e. geophones) via refracted ray-paths in the subsurface. S-wave velocity is primarily controlled by changes in density, whereas P-waves are controlled by changes in both density and material incompressibility. The depth of investigation is related to the length of the geophone array deployment and amplitude of the source used. Geophones can be deployed in boreholes to measure the velocity of waves generated at the surface, a practice called vertical seismic profiling (VSP). SRT (and VSP) surveys are typically used to identify subsurface discontinuities and the elastic moduli of stratigraphic layers, which can provide information on the stratigraphic and hydrogeological state of subsurface materials (e.g. Whiteley et al., 2020). If only two seismic receivers are used, spectral analysis of surface waves (SASW) between simultaneously recorded wave fields can be used to provide an estimate of the vertical 1D profile of S-wave velocity and shear modulus (Stokoe et al., 1994). More commonly, the multi-channel analysis of surface waves (MASW) technique measures the group of phase-velocity of surface (Rayleigh) waves (Park et al., 1999) to produce a 2D S-wave velocity profile. MASW surveys can be used to identify stratigraphic 
Table 3

A brief overview of the 19 geophysical investigations of 22 landslide dams exemplifying the efficacy of geophysical methods for landslide dam investigation.

\begin{tabular}{|c|c|c|c|c|c|c|}
\hline Authors & Location & Trigger & $\begin{array}{l}\text { Geophysical methods } \\
\text { used }^{1}\end{array}$ & $\begin{array}{l}\text { Date of } \\
\text { failure }\end{array}$ & Survey objective & $\begin{array}{l}\text { Potential risk assessment / } \\
\text { hazard mitigation purpose }\end{array}$ \\
\hline $\begin{array}{l}\text { Papyrin } \\
\text { (2001) }\end{array}$ & $\begin{array}{l}\text { Murgab River/ Usoi, Pamirs } \\
\text { Mountains, Tajikistan }\end{array}$ & Co-seismic & $\begin{array}{l}\text { VSP (see Ischuk, } \\
\text { 2011) (plus ERT, } \\
\text { gravity and magnetic } \\
\text { surveys) }\end{array}$ & $1911 \mathrm{AD}$ & Stratigraphic investigation & Stability assessment \\
\hline $\begin{array}{l}\text { Meric et al. } \\
\quad(2005)\end{array}$ & $\begin{array}{l}\text { Romanche River/ } \\
\text { Séchilienne, French Alps, } \\
\text { France }\end{array}$ & $\begin{array}{l}\text { Hydrological and co- } \\
\text { seismic? }\end{array}$ & EM, ERT, SN, SP, SRT & Pre-failure & $\begin{array}{l}\text { Geomorphological/ } \\
\text { stratigraphic investigation }\end{array}$ & $\begin{array}{l}\text { Volume estimation for } \\
\text { modelling future landslide } \\
\text { dam formation }\end{array}$ \\
\hline $\begin{array}{l}\text { Pánek et al. } \\
\text { (2009) }\end{array}$ & $\begin{array}{l}\text { Ropičanka River/ Mount } \\
\text { Ropice, oravskoslezské } \\
\text { Beskydy Mountains, Czech } \\
\text { Republic }\end{array}$ & $\begin{array}{l}\text { Fault induced rock } \\
\text { weakening, possible co- } \\
\text { seismic or hydrological }\end{array}$ & ERT, GPR & $\begin{array}{l}\sim 1.5 \mathrm{ka} \mathrm{BP} \\
(14 \mathrm{C})\end{array}$ & $\begin{array}{l}\text { Geomorphological/ } \\
\text { stratigraphic investigation }\end{array}$ & $\begin{array}{l}\text { Understanding modes of } \\
\text { landslide dam formation to } \\
\text { assess future risks future risks }\end{array}$ \\
\hline $\begin{array}{l}\text { Delunel et al. } \\
\text { (2010) }\end{array}$ & $\begin{array}{l}\text { Vénéon River/ Lauvitel } \\
\text { Valley, French Alps, France }\end{array}$ & Hydrological? & ERT & $\begin{array}{l}\sim 4.7 \mathrm{ka} \mathrm{BP} \\
(10 \mathrm{Be})\end{array}$ & $\begin{array}{l}\text { Stratigraphic } \\
\text { investigation, volume } \\
\text { estimation }\end{array}$ & $\begin{array}{l}\text { Understanding modes of } \\
\text { landslide dam formation to } \\
\text { assess future risks }\end{array}$ \\
\hline $\begin{array}{l}\text { Bianchi- } \\
\text { Fasani et al. } \\
\text { (2011) }\end{array}$ & $\begin{array}{l}\text { Tasso River/ Scanno, } \\
\text { Central Appennines, Italy }\end{array}$ & Co-seismic? & $\begin{array}{l}\text { ERT, SRT, MASW, } \\
\text { VES }\end{array}$ & $\begin{array}{l}12-2.3 \mathrm{ka} \\
\mathrm{BP}(14 \mathrm{C})\end{array}$ & Stratigraphic investigation & Outburst flood risk assessment \\
\hline $\begin{array}{l}\text { Crosta et al. } \\
\text { (2010) }\end{array}$ & $\begin{array}{l}\text { Adda River/ Val Pola, } \\
\text { Mount Zandila, Italian Alps, } \\
\text { Italy }\end{array}$ & Hydrological? & SRT & $1987 \mathrm{AD}$ & Stratigraphic investigation & $\begin{array}{l}\text { Outburst flood risk assessment } \\
\text { / planning remedial } \\
\text { engineering measures }\end{array}$ \\
\hline Ischuk (2011) & $\begin{array}{l}\text { Murgab River/ Usoi, Pamirs } \\
\text { Mountains, Tajikistan }\end{array}$ & Co-seismic & $\begin{array}{l}\text { Description of } \\
\text { selected data } \\
\text { described in Papyrin } \\
(2001)\end{array}$ & $1911 \mathrm{AD}$ & Stratigraphic investigation & Outburst flood risk assessment \\
\hline $\begin{array}{l}\text { Plaza et al. } \\
\text { (2011) }\end{array}$ & $\begin{array}{l}\text { Paute River/ La Josefina, } \\
\text { Parquiloma (Cerro } \\
\text { Tamuga), Andes, Ecuador }\end{array}$ & $\begin{array}{l}\text { Anthropogenic and } \\
\text { hydrological }\end{array}$ & SRT & $1993 \mathrm{AD}$ & Stratigraphic investigation & $\begin{array}{l}\text { Planning remedial engineering } \\
\text { measures }\end{array}$ \\
\hline $\begin{array}{l}\text { Grandjean } \\
\text { et al. } \\
\text { (2011) }\end{array}$ & $\begin{array}{l}\text { Doron-de-Pralognan River/ } \\
\text { Ballandaz, Savoie, France }\end{array}$ & Hydrological? & $\begin{array}{l}\text { EM, ERT, H/V, SASW, } \\
\text { SRT }\end{array}$ & Pre-failure & $\begin{array}{l}\text { Stratigraphic and } \\
\text { hydrogeological } \\
\text { investigation }\end{array}$ & $\begin{array}{l}\text { Volume estimation for } \\
\text { modelling future landslide } \\
\text { dam formation }\end{array}$ \\
\hline $\begin{array}{l}\text { Niazi et al. } \\
\quad(2010)\end{array}$ & $\begin{array}{l}\text { Jhelum River/ Hattian } \\
\text { Bala, Azad Kashmir, } \\
\text { Pakistan }\end{array}$ & Co-seismic & ERT & $2005 \mathrm{AD}$ & $\begin{array}{l}\text { Stratigraphic } \\
\text { investigation, seepage } \\
\text { monitoring }\end{array}$ & $\begin{array}{l}\text { Assessment of seepage or } \\
\text { piping failure potential }\end{array}$ \\
\hline $\begin{array}{l}\text { Wang et al. } \\
\text { (2013) }\end{array}$ & $\begin{array}{l}\text { Tributary of Mianyuan } \\
\text { River/ Tianchi, Sichuan } \\
\text { Province, China }\end{array}$ & Co-seismic & MASW & $2008 \mathrm{AD}$ & Stratigraphic investigation & $\begin{array}{l}\text { Assessment of seepage or } \\
\text { piping failure potential / } \\
\text { outburst flood risk assessment }\end{array}$ \\
\hline $\begin{array}{l}\text { Wang et al. } \\
\text { (2014b) }\end{array}$ & $\begin{array}{l}\text { Daduhe River/ Zhanggu, } \\
\text { Guza,Sichuan Province, } \\
\text { China }\end{array}$ & Co-seismic & MT & $\begin{array}{l}781-126 \\
\text { ka BP? }\end{array}$ & $\begin{array}{l}\text { Stratigraphic } \\
\text { investigation, } \\
\text { identification of sliding } \\
\text { surface }\end{array}$ & $\begin{array}{l}\text { Understanding modes of } \\
\text { landslide dam formation to } \\
\text { assess future risks }\end{array}$ \\
\hline $\begin{array}{l}\text { Torgoev et al. } \\
\text { (2013) }\end{array}$ & $\begin{array}{l}\text { Unamed river/ Ak-kul, } \\
\text { Minkush, Central Tien } \\
\text { Shan, Kyrgyzstan }\end{array}$ & Co-seismic? & ERT, H/V & "Ancient" & $\begin{array}{l}\text { Stratigraphic and } \\
\text { hydrogeological } \\
\text { investigation }\end{array}$ & $\begin{array}{l}\text { Seismic stability assessment / } \\
\text { seepage or piping failure } \\
\text { assessment }\end{array}$ \\
\hline $\begin{array}{l}\text { Torgoev et al. } \\
\text { (2014) }\end{array}$ & $\begin{array}{l}\text { Naryn River/ Kambarata } \\
\text { Hydroelectric Power Plant } \\
\text { 2, Central Tien Shan, } \\
\text { Kyrgyzstan }\end{array}$ & Anthropogenic & ERT & $2009 \mathrm{AD}$ & Seepage monitoring & $\begin{array}{l}\text { Seepage or piping failure } \\
\text { assessment }\end{array}$ \\
\hline $\begin{array}{l}\text { Wang et al. } \\
\text { (2014a) }\end{array}$ & $\begin{array}{l}\text { Qingzhu and Hongshi } \\
\text { River/ Donghekou, } \\
\text { Qingchuan County, Sichuan } \\
\text { Province, China }\end{array}$ & Co-seismic & MASW & $2008 \mathrm{AD}$ & $\begin{array}{l}\text { Stratigraphic } \\
\text { investigation, } \\
\text { identification of sliding } \\
\text { surface }\end{array}$ & $\begin{array}{l}\text { Outburst flood risk assessment } \\
\text { / planning remedial } \\
\text { engineering measures }\end{array}$ \\
\hline $\begin{array}{l}\text { Wang et al. } \\
\text { (2016a) }\end{array}$ & $\begin{array}{l}\text { Imo River/ Higashi- } \\
\text { Takezawa District, Niigata, } \\
\text { Japan }\end{array}$ & Co-seismic & MASW & $2004 \mathrm{AD}$ & Stratigraphic investigation & Outburst flood risk assessment \\
\hline \multirow[t]{4}{*}{$\begin{array}{l}\text { Wang et al. } \\
\text { (2018b) }\end{array}$} & $\begin{array}{l}\text { Unamed river/ Akatani, } \\
\text { Nara Prefecture, Japan }\end{array}$ & Hydrological & MTM, SP & $2011 \mathrm{AD}$ & Seepage identification & $\begin{array}{l}\text { Seepage or piping failure } \\
\text { assessment }\end{array}$ \\
\hline & $\begin{array}{l}\text { Unamned river/ Kuridaira, } \\
\text { Nara Prefecture, Japan }\end{array}$ & Hydrological & MTM, SP & $2011 \mathrm{AD}$ & & \\
\hline & $\begin{array}{l}\text { Imogawa River/ Terano, } \\
\text { Niigata Prefecture, Japan }\end{array}$ & Co-seismic & MTM, SP & $2004 \mathrm{AD}$ & & \\
\hline & $\begin{array}{l}\text { Kegeti River/ Kol-Tor, } \\
\text { Kyrgyzstan }\end{array}$ & & & $>0.2 \mathrm{ka} \mathrm{BP}$ & & \\
\hline $\begin{array}{l}\text { Wang et al. } \\
\text { (2018a) }\end{array}$ & $\begin{array}{l}\text { Experimental setup, Eshima } \\
\text { Island, Shimane Prefucture, } \\
\text { Japan }\end{array}$ & Anthropogenic & SP & Recent & $\begin{array}{l}\text { Precursory failure } \\
\text { condition }\end{array}$ & $\begin{array}{l}\text { Understanding modes of } \\
\text { landslide dam formation to } \\
\text { assess future risks / outburst } \\
\text { flood risk assessment }\end{array}$ \\
\hline $\begin{array}{l}\text { Havenith } \\
\text { et al. } \\
\text { (2015) }\end{array}$ & $\begin{array}{l}\text { Naryn River/ Kambarata } \\
\text { Hydroelectric Power Plant } \\
\text { 2, Central Tien Shan, } \\
\text { Kyrgyzstan }\end{array}$ & Anthropogenic & ERT, H/V & $2009 \mathrm{AD}$ & $\begin{array}{l}\text { Seepage monitoring, } \\
\text { stratigraphic investigation }\end{array}$ & $\begin{array}{l}\text { Seepage or piping failure } \\
\text { assessment / seismic stability } \\
\text { assessment }\end{array}$ \\
\hline $\begin{array}{l}\text { Havenith } \\
\text { et al. } \\
\text { (2018) }\end{array}$ & $\begin{array}{l}\text { Vakhsh River/ Rogun } \\
\text { Hydroelectric Power Plant, } \\
\text { Tajikistan }\end{array}$ & $\begin{array}{l}\text { Potentially seismically } \\
\text { triggered }\end{array}$ & ERT, SRT, H/V & Pre-failure & $\begin{array}{l}\text { Geomorphological/ } \\
\text { stratigraphic investigation }\end{array}$ & $\begin{array}{l}\text { Seepage or piping failure } \\
\text { assessment / seismic stability } \\
\text { assessment }\end{array}$ \\
\hline
\end{tabular}


${ }^{1} \mathrm{EM}=$ Electromagnetic, ERT $=$ Electrical resistivity tomography, GPR $=$ Ground penetrating radar, H/V = Horizontal-to-vertical noise ratio, MASW $=$ Multi-channel analysis of surface waves, MTM = Micro-tremor method, MT = Magnetotellurics, SASW $=$ Spectral analysis of surface waves, $\mathrm{SN}=\mathrm{Seismic}$ noise analysis, $\mathrm{SP}=\mathrm{Self}-$ potential, SRT $=$ Seismic refraction tomography, VES $=$ Vertical electrode sounding, VSP = Vertical seismic profile. ${ }^{2}$ ERT, gravity and magnetic survey results not accessed, VSP data described in part by Ischuk (2011).

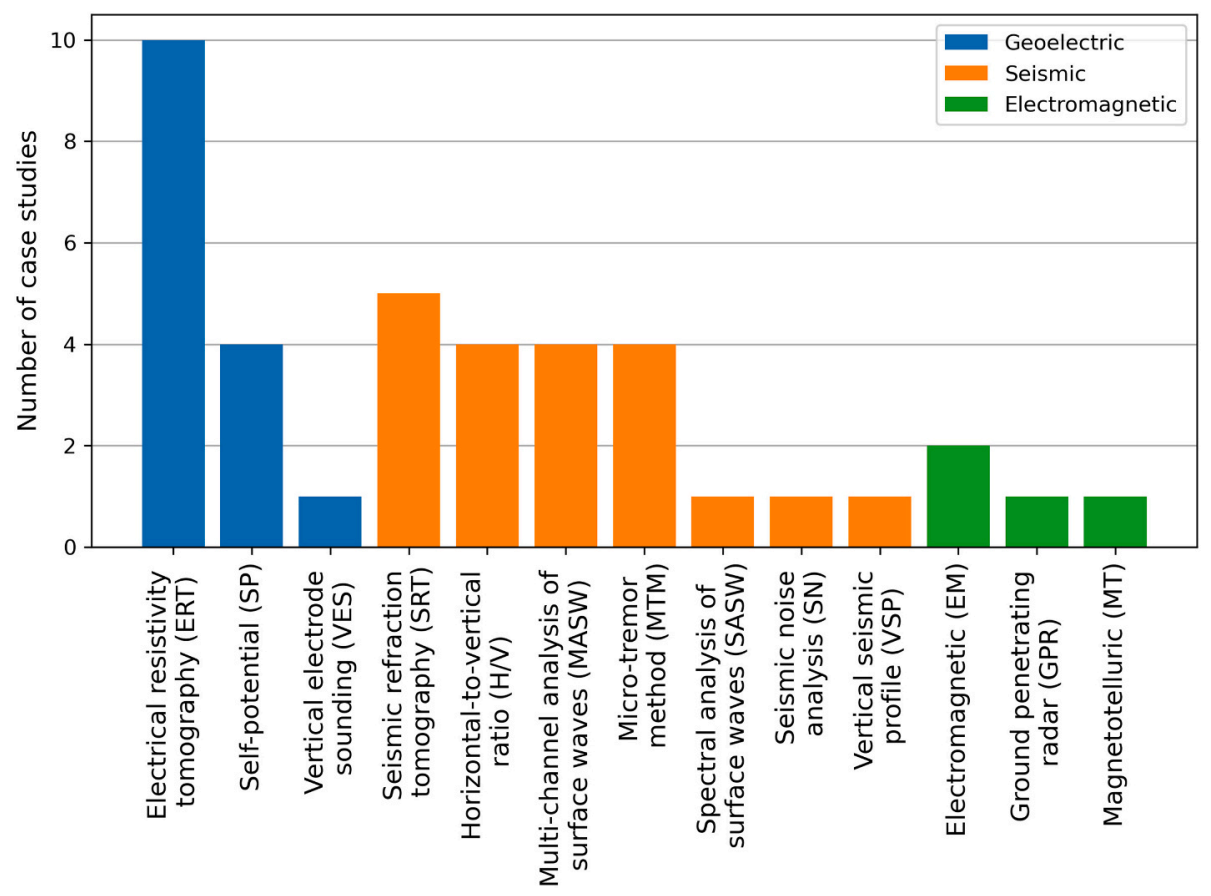

Fig. 4. The number of different geophysical survey methods used to investigate the internal structure landslide dams from the data in Table 3.

boundaries in the subsurface, as well as provide information on material stiffness (e.g. Donohue et al., 2011).

By recording naturally occurring, passive seismic signals (called 'ambient noise') and analyzing the corresponding horizontal-to-vertical spectral ratio $(\mathrm{H} / \mathrm{V})$, material stiffness can be estimated (Castellaro et al., 2005). If multiple seismic receivers are used, the micro-tremor method (MTM) can determine 2D subsurface structures (Okada and

A)

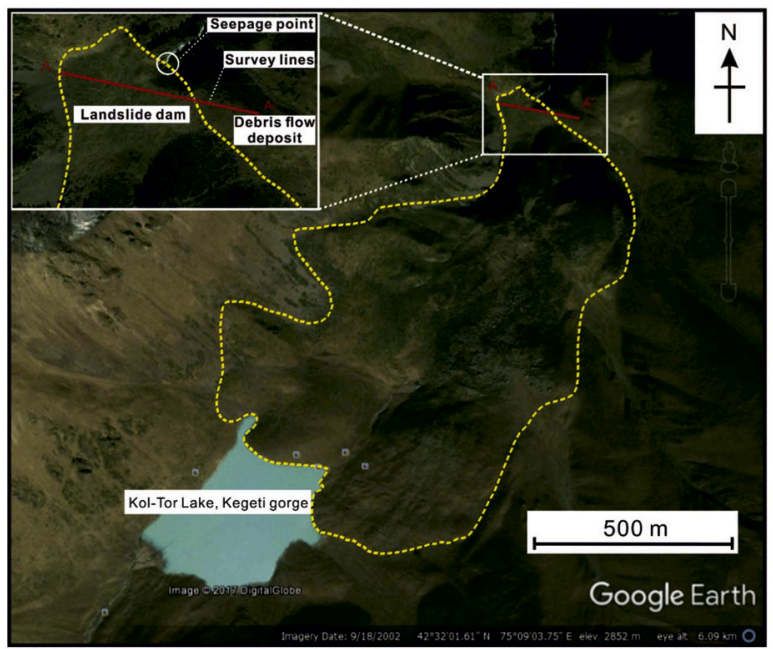

Suto, 2003). In addition, simply recording the seismic noise (SN) and analysing the spectral amplitude gives estimations of possible resonance phenomena that may occur in seismically unstable settings (Field and Jacob, 1993).

2.3.5. Examples of geophysical investigations of landslide dams Geophysical surveys can be used to assess the volume of unstable
B)

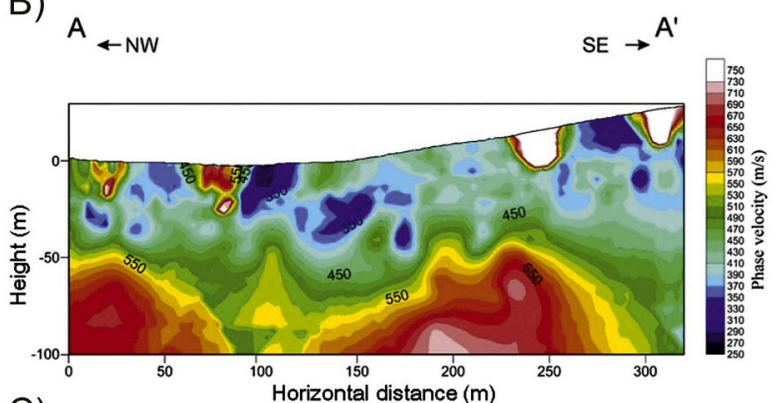

C)

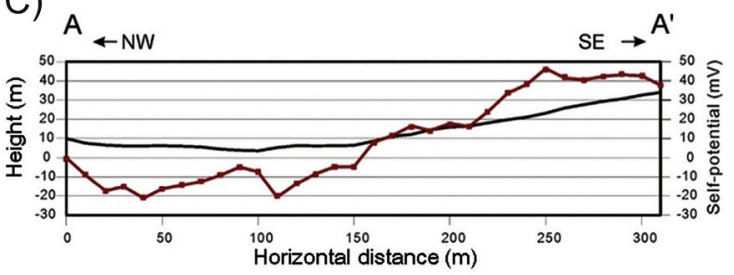

Fig. 5. (A) The Kol-Tor lake and landslide dam in the Kyrgyz Republic showing the geophysical survey profile crossing the emplaced landslide dam $(0-220 \mathrm{~m}$ horizontal distance) and debris flow deposit (220 - $310 \mathrm{~m}$ horizontal distance), (B) the results of the micro-tremor method survey, indicating areas of low-velocity ground associated with destabilization due to seepage at $80 \mathrm{~m}, 150 \mathrm{~m}$ and $170 \mathrm{~m}$ horizontal distance, and (C) the results of the self-potential from the same profile, with elevated readings in the landslide dam corresponding with the active seepage zone at $150 \mathrm{~m}$ horizontal distance. Modified with permission from Wang et al. (2018b). 
slopes that may form future landslide dams. Meric et al. (2005) and Grandjean et al. (2011) used a combination of EM, ERT, SRT and SN methods to investigate the dimensions of two landslides that are at risk of damming rivers. More commonly, geophysical studies are used to investigate existing, recently formed landslide dams. For example, Wang et al. (2014a) used MASW surveys to demonstrate that bulk densities of the emplaced landslide-dam material were similar to those of the preexisting slope.

The sedimentology of historic landslide dams can be a target for geophysical investigations. A detailed reconstruction of late-Holocene deep-seated gravitational slope deformation and toppling events at Ropice Mountain in the Czech Republic was aided by the use of ERT measurements and GPR profiles (Pánek et al., 2009). Additionally, geophysical surveys may be used to identify potential failure modes in seemingly stable dams. The Kol-Tor landslide dam in the Kyrgyz Republic was monitored using MTM and SP by Wang et al. (2018a). They identified seepage routes in the long-existing dam, with the combined results from the separate surveys (Fig. 5) improving the confidence of identified seepage zones. Geophysical surveys are also used to assist in the engineering of landslide dams, such as at the Karambata Hydro Power Plant 2 in Kyrgyz Republic (Havenith et al., 2015; Torgoev et al., 2014; see 2.4.2 below).

\subsubsection{Summary and outlook}

Geophysical methods are increasingly used to investigate the properties and condition of landslide dams. These methods can characterize the total thickness, internal structure, and geotechnical properties of landslide dams in a rapid and non-invasive manner. Survey results can help assess dam stability by identifying material heterogeneities that indicate zones of weakness or fluid flow. Recent innovations in geophysical monitoring approaches can provide ongoing assessments of landslide dam stability, and identification of evolving zones of weakness that may lead to dam failure.

However, geophysical surveys provide indirect observations, with measurements acting as proxies for ground conditions. They require careful interpretation supported by multi-technique surveys, and comparison with observed ground properties from laboratory or field observations. Where possible, data should be calibrated by measurements in near geological outcrops or across known geological cross-sections that allow for extrapolations of results deeper into the dam structure.

\subsection{Dam sedimentology and geotechnical properties}

\subsubsection{Landslide dam sedimentology}

One approach to assess the type of landslide dam and its composition is to regard it simply as a landslide deposit. In their review of the Varnes (1978) classification of landslide types, Hungr et al. (2014, p.171) emphasize that "the goal of landslide classification systems is to stress the component that is the most important in determining the mechanical behavior of the landslide during and post-failure". The material classes in their classification span the full spectrum of soils (and their corresponding unified soil classes), rock, ice, and peat. Consequently, the different landslide types form deposits of very different sedimentology (composition, grain size distributions, etc.), structure (faults, layers, etc.), geotechnical (density, strength parameters, etc.) and hydrogeological properties (permeability, etc.). In addition, differences in river-blocking deposit volumes and thicknesses vary over several orders of magnitude depending on the source region and valley geometry, as well as on the proportion of the landslide actually blocking the river (e.g. Miller et al., 2018). This can make adjustments of existing classification schemes necessary when addressing landslide dam stability (c.f. Fan et al., 2020). For example, the 2008 Wenchuan earthquake exemplified the diversity of landslides forming dams. In its aftermath, Fan et al. (2015) identified three types of landslide dams: (1) dams mainly composed of large boulders and blocks, (2) dams dominated by unconsolidated fine debris, and (3) layered dams with partly intact rock strata at the base overlain by larger boulders and blocks or soil with rock fragments (see also Fan et al., 2020).

Multi-layered deposits are common for large $\left(>10^{6} \mathrm{~m}^{3}\right)$ rockslides (RS) and rock avalanches (RA). For these landslide types, a three-part facies model of an upper coarse carapace, a heterogeneous body of highly fragmented debris, and a basal facies or mixed zone with incorporated substrates has become widely accepted (e.g. Davies and McSaveney, 2011; Dufresne et al., 2016; Dunning, 2006; Dunning and Armitage, 2011; Heim, 1932; Strom, 2006; Weidinger et al., 2014). The large boulders of the carapace may form a network dense enough to armor the deposit effectively against erosion by overtopping water flow similar to engineered rip-rap. The largest volume of RS/RA deposits, however, is made up by the body facies. This highly heterogeneous, fragmented interior consists of various sub-facies-some common across many deposits, others specific to individual deposits depending on source structures and emplacement conditions (Fig. 6). Each sub-facies varies in spatial distribution and geotechnical properties. For example, facies-distribution within the carbonate Flims rockslide in Switzerland influenced the location of incision through the $\sim 400$-m-thick deposit (Wassmer et al., 2004). At Flims, the uppermost granular and intermediate facies have clast-in-matrix fabrics and spillways were found in two locations, with the more proximal one terminating at $1,060 \mathrm{~m}$ asl at the transition from the intermediate to the 'structured facies' (the latter described as a 'thick layer of rock'). In a more distal location, this boundary is at around $900 \mathrm{~m}$ asl and the broad spillway within the upper intermediate facies narrows where it cuts through the more resistant structured facies (all descriptions from Wassmer et al. (2004)).

The reviews of Weidinger et al. (2014) and Dufresne et al. (2016) show that any inverse grading in RA or RS deposits is limited to the carapace-body transition (Fig. 6B). Hence, reverse grading sensu strictu (i.e. a systematic change in grain size from one end to the other) does not apply to rockslide and rock avalanche deposits. Source stratigraphy is typically preserved in these deposits (e.g. Abdrakhmatov and Strom, 2006; Heim, 1932; Hewitt et al., 2008; Weidinger et al., 2014), and, depending on original bedding orientations and sliding geometry, results in specific horizontal or lateral distribution of lithologies (e.g. Hartvich, 2008; Strom, 2006; Strom, 2010) that influence where erosion and breach may occur.

Additionally, transitions in transport and emplacement behavior of the landslide influence the degree of comminution and hence the deposit grain-size distribution and erodibility. For example, a late-Pleistocene rockslide in the Betic Cordillera transformed from a proximal, wellstratified planar rockslide deposit into a highly comminuted rock avalanche, which resulted in several depositional facies (García-García et al., 2011). Further dynamic changes induced during landslide transport and emplacement include mixing with valley-fill sediments, water and/or ice as well as phase transition into debris avalanches and/or fully saturated debris flows (the 'complex' landslide type of Cruden and Varnes, 1996). Each of these transitions changes not only the dynamic behavior of the landslide, but also the thickness, morphology, and geotechnical properties of the resulting deposits.

Post-emplacement modifications, such as self-compaction under overburden, precipitation of minerals, inflow of fine sands and clays, or debris fans forming at the downstream face can alter dam permeability, erodibility, and overall material strength. Korchevskiy et al. (2011), for example, observed a decrease in seepage through the Burlykiya blast-fill dam during the first month after dam formation at constant lake level, and attributed this to the natural formation of reverse filters due to transfer of fine particles within the dam.

\subsubsection{Landslide dam geotechnical properties}

The presence (and distribution) or absence of an armoring carapace of large boulders that could protect from, or slow, downward erosion and spillway formation can reduce the risk of, or increase the time to, an overtopping failure. Even though the carapace is more permeable (as it is an openwork structure) and less dense than the lower levels, the larger 


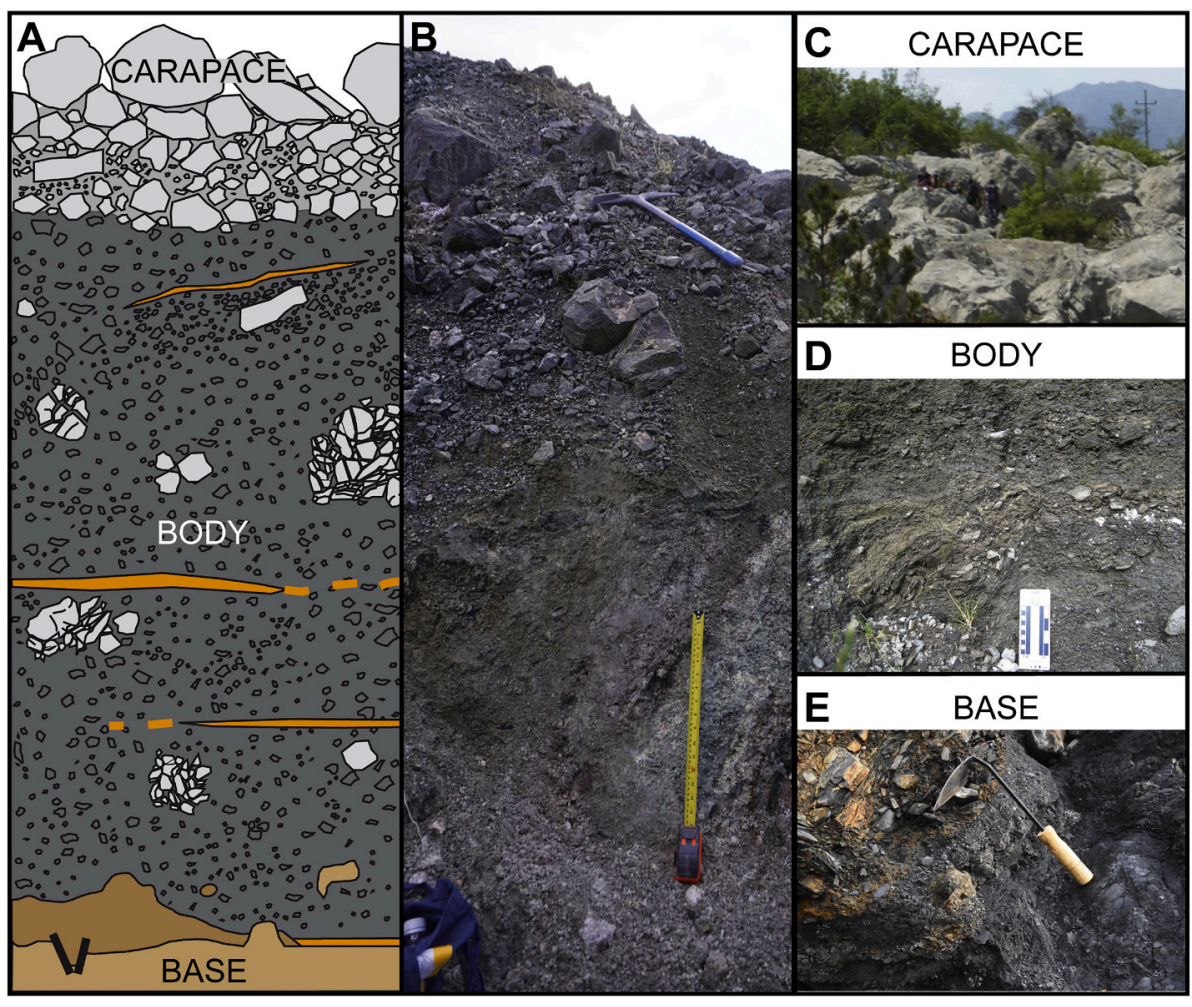

Fig. 6. (A) Typical three-part facies model of an upper coarse carapace (light grey), a heterogeneous body facies (dark grey) with jigsaw-fractured and survivor clasts (larger light grey areas) and shear zones (orange), and the basal facies with a mixed zone (brown), basal shear (orange), faulting (black lines) and injection of in situ substrate (ochre). (B) Transition from carapace to body facies with intact stratigraphic succession near the 40-cm-long tapemeasure (Harold Price rock avalanche, British Columbia, Canada). (C) Prominent carapace at the Le Marocche rockslide in Italy (note people for scale). (D) Sheared but intact lithological succession in the mylonitic Round Top rock avalanche, New Zealand. (E) Example of a basal contact of the rockslide near the Longtangping village, Mianyang County, Sichuan, China. clast sizes make it more resistant to mobilization/entrainment by water flows. Large boulders collapsing into a developing spillway can also restabilize the breach channel and stop or slow further downward erosion (e.g. Plaza et al., 2011), as well as create a hydrologically rougher, inefficient flow.

Permeability of the dam interior controls the formation of an upstream lake as well as the equilibration of inflow into the impoundment and seepage through or around the dam to keep the lake at a level below overtopping (e.g. at the Usoi dam of the Sarez Lake in Pamir; Hanisch and Söder, 2000; Ischuk, 2011). On the other hand, seepage may lead to internal erosion and consequent dam failure by piping (e.g. Dunning et al., 2006). This failure type is, however, rare in landslide dams, highlighting their resistance to suffusion. Davies and McSaveney (2006) attribute the rarity of piping or slumping as a failure mechanism of landslide dams to the typically heterogeneous grain-size distribution and very small average void size within the dams. Furthermore, the spatial distribution of different lithologies and depositional facies with unique properties, such as permeability or critical erosive shear stress, will affect internal water flow.

Relatively few studies have detailed the geotechnical aspects of landslide dams. The data in Table 4 are variously based on field or laboratory tests of dam material, derived from numerical stability analyses or assumed through comparison with similar materials. Several studies report consistent changes in geotechnical properties with depth within the dam. Compressed rock density in a blast-fill dam increases from $\sim 1.7$ tons $/ \mathrm{m}^{3}$ near the surface to just over 2.0 tons $/ \mathrm{m}^{3}$ at depth (Korchevskiy et al., 2011). The Val Pola rockslide in Italy shows progressive decrease of hydraulic conductivity from $10^{-3} \mathrm{~m} / \mathrm{s}$ near the top to $10^{-6} \mathrm{~m} / \mathrm{s}$ at $70 \mathrm{~m}$ depth, though the data scatter at similar depths is around two orders of magnitude (Crosta et al., 2010).

Other studies point to the influence of material characteristics on dam longevity from a purely empirical and observational perspective, stating that dams composed of coarser debris and those that are grainsupported or made up of cohesive particles last longer (Costa and Schuster, 1988; Ermini and Casagli, 2003; Weidinger et al., 2014). Comparing landslide type and grain-size distribution with dam longevity for 13 cases, Weidinger (2011) suggests that rockslides (blocks; $n=3$ ) exceed rock avalanches (boulders; $n=7$ ), which in turn exceed landslides composed of overall finer-grained debris $(n=3)$ in structural longevity. Schuster (1986); (Schuster, 1995) conclude that dams formed from large boulders or cohesive clays are less likely to fail than highly permeable or unconsolidated dams. They further state that the characteristics of volcanic debris avalanche deposits (usually compact, poorly sorted, block-in-matrix fabrics with a high proportion of sand-to-clay-sized particles) inhibit filtration, thereby promoting water accumulation to the level of overtopping. Recently, Fan et al. (2020) compared longevity against the landslide type forming the dam (based on data using 410 worldwide landslide dams). Their analysis shows that $80 \%$ of complex, $65 \%$ of debris flows, and $\sim 60 \%$ of dams in unconsolidated sediments have a longevity of less than one year, whereas dams of rock/debris avalanches and rockslides last longer. They further suggest that the influence of landslide or material type on the longevity of a landslide dam decreases beyond the first year, and beyond 10 years, about $30-40 \%$ of the dams survived regardless of the landslide type.

Over time, weathering, mineralization and cementation influence the performance of dams. Korchevskiy et al. (2011; p. 625) summarize that "siltstone, mudstone, sandstone and conglomerate with clayey and carbonate-clayey cement and some varieties of shale and gneiss undergo rapid and intense weathering", which can lead to density heterogeneities and a high infiltration gradient, and may increase the potential for piping and internal erosion. Prager et al. (2009) and Weidinger et al. (2014) note the influence of secondary cementation after groundwater and meteoric waters percolate through dam materials. Such cementation can significantly alter water pathways over time. Dunning and Armitage (2011) modelled landslide dam stability numerically (both with and without a carapace) through which phreatic tonguing occurred due to the highly permeable openwork structure, which significantly decreased downstream face stability. It is this mode of failure, with observed seepage front progression up the downstream dam-face that caused the slumping failure of the Tsatichhu rock-avalanche dam in Bhutan (Dunning et al., 2006). Xu et al. (2009) categorized failed 
Table 4

Geotechnical properties of selected landslides dams.

\begin{tabular}{|c|c|c|c|c|c|c|c|c|c|c|c|}
\hline \multicolumn{12}{|c|}{ Higashi-Takezawa landslide (Japan): siltstone, sediments, 93\% fine sand (Wang et al., 2016a) } \\
\hline $\mathrm{V}\left[10^{6} \mathrm{~m}^{3}\right]$ & $\mathrm{Y}\left[\mathrm{kN} / \mathrm{m}^{3}\right]$ & & $\rho_{\text {bulk,dry }}\left[\mathrm{g} / \mathrm{cm}^{3}\right]$ & $\rho_{\text {rock }}\left[\mathrm{g} / \mathrm{cm}^{3}\right]$ & $\mathrm{W}[\%]$ & $\mathrm{e}$ & $\mathrm{c}\left[\mathrm{kN} / \mathrm{m}^{2}\right]$ & $\mathrm{c}^{\prime}\left[\mathrm{kN} / \mathrm{m}^{2}\right]$ & $\theta\left[{ }^{\circ}\right]$ & $\kappa[\mathrm{cm} / \mathrm{s}]$ & $\tau_{\mathrm{c}}[\mathrm{Pa}]$ \\
\hline \multirow{4}{*}{1.3} & 18 & Sliding plane: & & & & & 25.5 & & 18.0 & & \\
\hline & & Head: & 1.20 & 2.69 & 32.0 & 1.25 & & & & $9.99 \times 10^{-5}$ & \\
\hline & & Central: & 1.38 & 2.63 & 21.4 & 0.92 & & 19.8 & 35.6 & $1.41 \times 10^{-2}$ & 0.32 \\
\hline & & Toe: & 1.47 & 2.64 & 28.1 & 0.80 & & 27.8 & 36.5 & $3.02 \times 10^{-6}$ & \\
\hline
\end{tabular}

\begin{tabular}{|c|c|c|c|c|c|c|c|c|c|c|c|}
\hline \multicolumn{12}{|c|}{ Hsiaolin colluvium slide (Taiwan), longevity: 84 minutes (Dong et al., 2011b) } \\
\hline $\mathrm{V}\left[10^{6} \mathrm{~m}^{3}\right]$ & $\mathrm{D}_{50}[\mathrm{~mm}]$ & $\mathrm{D}_{10}[\mathrm{~mm}]$ & Soil class & $\mathrm{Y}\left[\mathrm{kN} / \mathrm{m}^{3}\right]$ & GS & $\mathrm{W}$ [\%] & $\mathrm{c}^{\prime}\left[\mathrm{kN} / \mathrm{m}^{2}\right]$ & $\theta\left[{ }^{\circ}\right]$ & $\kappa[\mathrm{cm} / \mathrm{s}]$ & LL [\%] & $\overline{\text { PL [\%] }}$ \\
\hline \multirow[t]{4}{*}{$25.2(15.4)$} & 0.24 & 0.005 & SC & 20.1 & 2.85 & 3.4 & 6 & 22 & $1 \times 10^{-5}$ & 24.1 & 7.5 \\
\hline & 0.09 & 0.003 & SM & 20.6 & 2.56 & 1.7 & & & & 23.1 & 3.6 \\
\hline & 0.40 & 0.003 & SC & 21.3 & 2.80 & 1.8 & & & & 25.6 & 7.7 \\
\hline & 0.07 & 0.002 & CL & 21.7 & 2.71 & 1.8 & & & & 29.5 & 7.8 \\
\hline
\end{tabular}

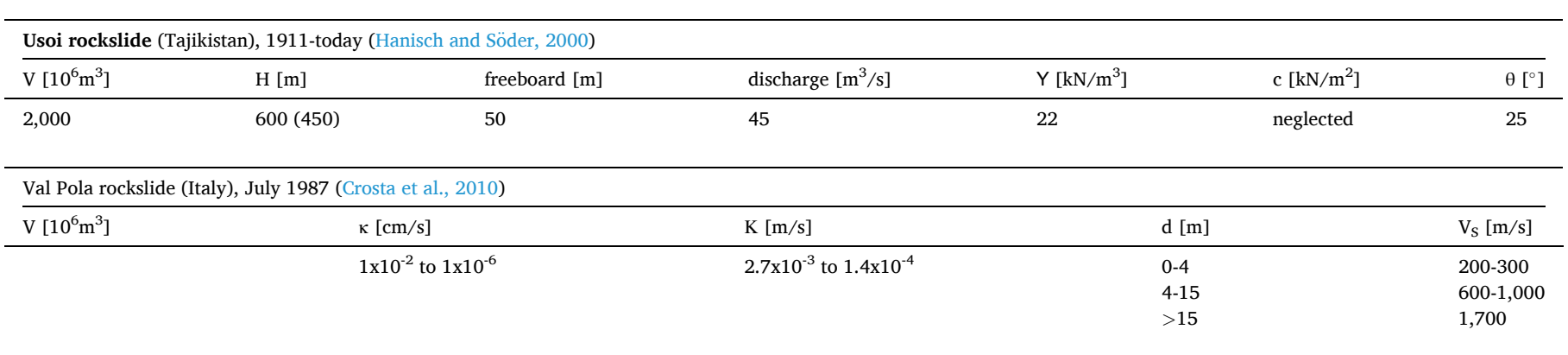

\begin{tabular}{|c|c|c|c|c|c|c|c|}
\hline \multicolumn{8}{|c|}{ La Josefina, 1993 (Plaza et al., 2011) } \\
\hline $\mathrm{V}\left[10^{6} \mathrm{~m}^{3}\right]$ & $\mathrm{H}[\mathrm{m}]$ & $\mathrm{D}_{10}[\mathrm{~mm}]$ & $\mathrm{D}_{90} / \mathrm{D}_{30}$ & $\mathrm{Y}\left[\mathrm{kN} / \mathrm{m}^{3}\right]$ & porosity [\%] & $\mathrm{c}\left[\mathrm{kN} / \mathrm{m}^{2}\right]$ & $\theta\left[{ }^{\circ}\right]$ \\
\hline 20 & 100 & 100 & 30 & 27.6 & 15 & 5 & 45 \\
\hline \multicolumn{8}{|c|}{ Kambarata blast-fill dam, rockslide (Havenith et al., 2015) } \\
\hline $\mathrm{V}\left[10^{6} \mathrm{~m}^{3}\right]$ & $\mathrm{H}[\mathrm{m}]$ & & & & $\mathrm{c}\left[\mathrm{kN} / \mathrm{m}^{2}\right]$ & $\theta\left[{ }^{\circ}\right]$ & $\mathrm{K}[\mathrm{m} / \mathrm{s}]$ \\
\hline 0.78 & $25-30$ & Raised wi & ad, etc. to & of $50 \mathrm{~m}$ & 200 & 38 & $\begin{array}{l}4 \times 10^{-3} \text { (initial) } \\
3 \times 10^{-5} \text { (calibr.) }\end{array}$ \\
\hline
\end{tabular}

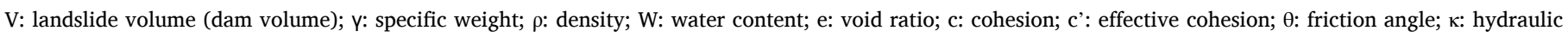

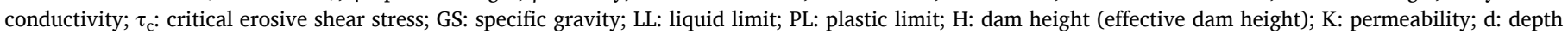
below dam surface; $V_{S}$ : shear wave velocity

landslide dams from the 2008 Wenchuan earthquake, classifying the main dam materials, but not their internal heterogeneity or distribution of discrete facies.

Much can be learned from the study of artificial dams or from the construction and analysis of blast-fill dams. In blast-fill dam design, the dams are essentially treated as deposits with two zones of contrasting permeability: the upper carapace and the body (Adushkin, 2006; Adushkin, 2011; Korchevskiy et al., 2011). Reservoir levels are recommended to be kept below the facies transition because "the abrupt difference between the permeability of the upper and lower parts may lead to internal erosion if high discharge through the void spaces in the carapace directly affects the underlying comminuted debris" (Korchevskiy et al., 2011; p. 633). The basal facies is usually neglected, and coarse talus and trees in the emplacement area removed prior to blasting to reduce permeability in the dam foundation. According to the same authors, the compressed rock density of blast-fill and natural rockslide dams exceed that of embankment dams. They identified three blast-fill dams at which $70-80 \%$ of the increase in dam-body density occurred in the first year after emplacement. This suggests that if a dam survives the first year, progressive changes in geotechnical properties may increase the likelihood of continued future stability, which is in agreement with the empirical observations by Fan et al. (2020) mentioned above.

At the Karambata Hydro Power Plant 2 in Kyrgyz Republic, Havenith et al. (2015) and Torgoev et al. (2014), using ERT to assess compaction after the emplacement of a blast-fill dam showed high resistivity zones in the blast-fill material (about $75 \%$ of the dam volume), indicating good compaction. This blast-fill material was shown to be in better engineering condition than the earth-fill later introduced to cover the blastfill materials.

In contrast to rock-fill-dominated natural and artificial dams are those created by landslides in unconsolidated sediments, and debris flows. Besides significant differences in the source material, their deposits are more homogenous, since intensive fragmentation does not occur (which results in the distinct three-facies structure typical of most of rock avalanche dams), and many debris flows are turbulent, resulting in different grain-size compositions and distributions. The major factor influencing the sedimentology of unconsolidated natural dams is the role of water in the formation and motion of the landslides, especially in debris flows. Water-enriched debris has low internal friction angles and such dams are rarely as high as dams formed by 'dry' rockslides or rock avalanches.

\subsubsection{Summary and outlook}

The data presented in this section is a collation from detailed sedimentological and geotechnical analyses of landslide deposits, geophysical investigations of both, landslides and landslide dams, and insights from artifical blast-fill dams. The way forward in landslide dam analyses is, in our view, the continuation of such multidisciplinary investigations. They expand our knowledge of (i) landslide composition, structure, and geotechnical properties, which can be transferred to dam stability 
assessments, and (ii) dam performance and changes in properties over time.

\section{Recent Advances in landslide dam analyses}

In this section, we take a closer look at dam failure modes and the processes involved therein. We review recent insights from physical analogue modelling and data from well-documented failures of embankment dams. This is followed by an overview of how potential hazard cascades (or individual processes therein) can be assessed through numerical modelling.

\subsection{Dam failure modes and insights from analogue models}

Landslide dams, and artificial water-retaining structures such as earth- or rockfill (embankment) dams, can fail by overtopping, piping or slope failure (Korup, 2002; Schuster et al., 1992). The majority of landslide dams that formed and rapidly failed in historic times breached through overtopping (Costa and Schuster, 1988; Peng and Zhang, $2012 b)$. This is a process of fluvial erosion wherein erosion starts at the downstream side of the dam and progressively moves upstream and downward into the dam body (Fig. 7A, E). Failure due to piping, on the other hand, plays a larger role in embankment dams than in landslide dams. Two definitions of this phenomenon exist. One defines it as seepage through the dam body (Fig. 7B), which eventually develops into an erosive flow and can lead to dam failure-where the erosive flow starts is not specified. The other definition, usually applied in an engineering context, addresses 'piping' as an erosive flow in the foundation below a dam body (Fig. 7C). For natural dams, however, erosive flow below the dam (i.e. through the underlying sediments) has never been reported since water typically finds pathways through the dam body itself, and therefore we use the term 'piping' to refer to seepage through a dam body only. Failure initiated by the collapse of the downstream slope (Fig. 7D) is rare in natural dams (Fig. 7E).

In a review of 11,192 published cases of embankment dam failures, Foster et al. (2000) report that overtopping accounts for $48.4 \%$ and piping for $46.1 \%$ of the total number of failures (Fig. 7E). Zhang et al. (2009a) reviewed 593 cases of earthfill dam failures and found that $36.4 \%$ of the dams failed by overtopping, whereas dam quality problems (piping, sliding, spillway defects, etc.) comprised $42.5 \%$ of the dominant causes of dam failure. Of these dam quality problems, 58.3 and $18.3 \%$ of the dam failures were caused by piping and sliding, respectively. Similarly, Peng and Zhang (2012b), analysing 144 cases of landslide and 176 cases of embankment dam failures found that $1 \%, 8 \%$, and $91 \%$ cases of landslide dam failures were caused by slope failure, piping, and overtopping, respectively. On the other hand, slope failure, piping, and overtopping accounted for $5 \%, 37 \%$, and $58 \%$ cases of failures for embankment dams.

Shen et al. (2020) statistically analyzed the longevity of landslide dams based on a database with 1,737 cases, among which 352 cases were well recorded with longevity information and overtopping failure. According to the interaction between the dam and the lake water, the longevity of landslide dams can be divided into three stages: infilling, overflowing and breaching. Their three-stage regression model shows better accuracy than that of the full longevity regression model because it considers the influencing factors of each stage.

Given the sparse research to date on the engineering behaviour and failure mechanisms of natural river blockages, physical modelling provides a solid means for understanding dam breach mechanisms, including the breach initiation process, breach parameters, breaching time, outflow hydrographs, and potential flood risk areas. However, the complexities associated with the failure of landslide dams have made the development of physical models very difficult. Notwithstanding, scientists and hydraulic engineers often prefer physical modelling over the development of numerical models due to the following reasons: (1) physical modelling allows for a better observation of the failure mechanisms of dams, under given space and time conditions; and (2) it allows for the inclusion of previously unknown parameters that could influence the stability of dams (Peakall et al., 1996; Young and Warburton, 1996).

To date, the focus of laboratory-scale modelling (and also of numerical modelling; cf. Section 3.2) has been on homogeneous earthfill dams. According to Singh (2013), the failure of earthfill dams is commonly induced by erosion of the dam material by transient water flow either over or through the dam. The former results in the overtopping of the dam, whereas the latter leads to seepage and internal erosion (piping). Several physical modelling approaches investigated piping and overtopping failures of earthfill dams and other river blockages, whereas few studies concentrated on the sliding mechanism of dam failures. For instance, Okeke et al. (2017) and Wang et al. (2018a) performed a series of large-scale physical (outdoor) experiments to investigate the precursory factors leading to piping-induced failure. Their results show that the high turbidity of the effluent

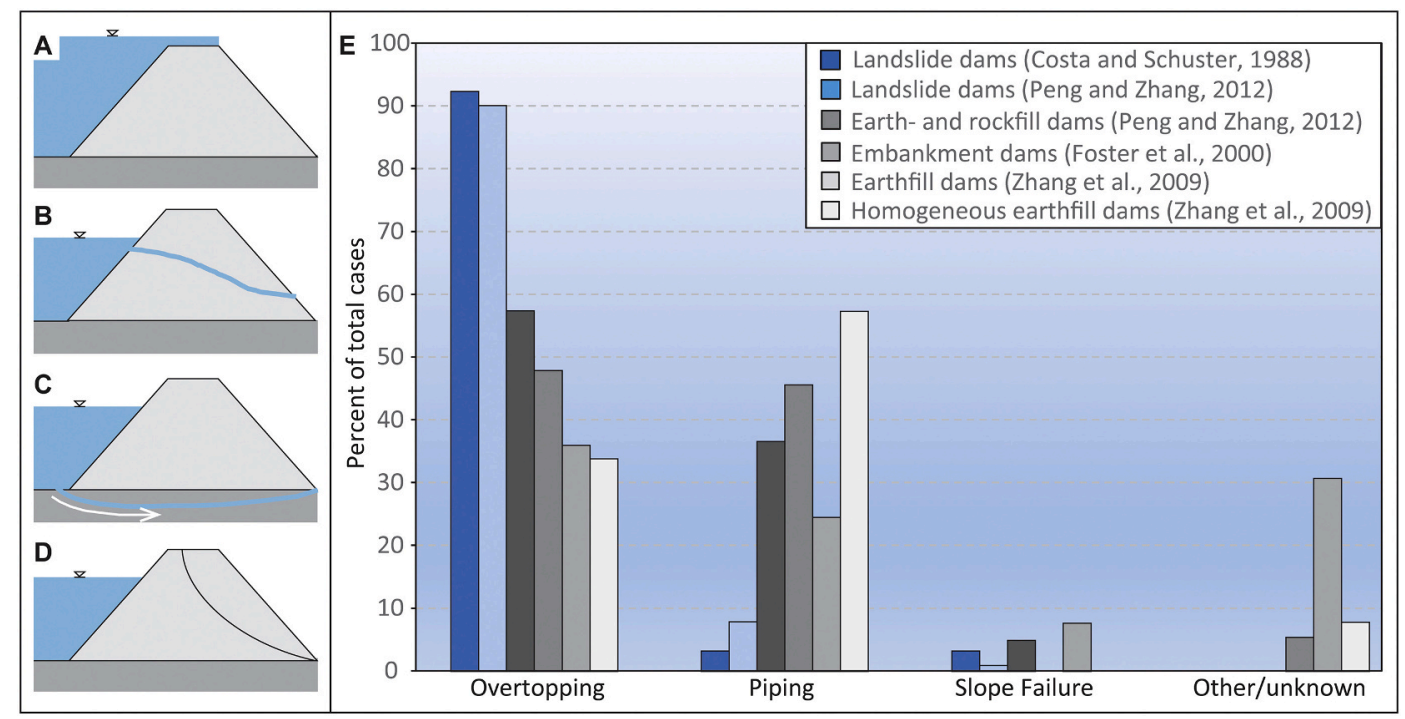

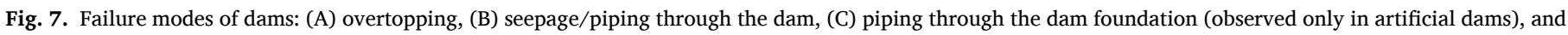

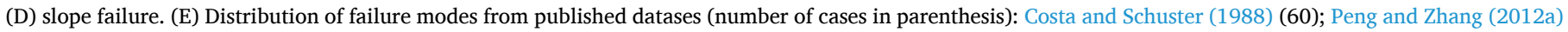
(144 landslide, 176 earth- and rockfill dams); Foster et al. (2000) (11,192); Zhang et al. (2009b) (593, thereof 38 homogeneous earthfill dams). 
seepage coincided with a decrease in self-potential values, together with several internal displacements and dam crest settlement. They concluded that the failure of the dam models comprises a four-phase process that includes the discharge of hyperconcentrated flow from the downstream toe, evolution of cracks on the dam crest, dam-crest settlement, and undercutting of the downstream toe. To study the failure mechanisms of landslide dams due to overtopping, Cao et al. (2011) used an $80-\mathrm{m}$ long by $1.2-\mathrm{m}$ wide by $0.8-\mathrm{m}$ deep flume tank with and without an initial notch on the dam crest, where the notch simulates an initial overtopping breach. They found that the peak discharge of the outflow hydrograph was higher in the dams built without an initial notch compared to dams with an initial notch.

\subsubsection{Overtopping failure}

The breaching of earthfill dams by overtopping is usually triggered by inadequate flood design that arises from excessive rainfall (Singh, 2013). In natural dams, overtopping-induced failure is commonly influenced by the volume and rate of discharge into the upstream lake, the size and geometry of the impoundment, and the geotechnical properties of the dam materials. The failure mechanism of dams by overtopping begins once water flows over the dam through its lowest level (depression). The flow of water over the downstream slope generates excessive shear stress, which initiates the erosion process. According to Singh (2013) and Schmocker and Hager (2009), particle mobilization and transport commence once the shear stress generated by the flow of water exceeds the critical shear stress of the dam material. Wang et al. (2016b) summarize empirical equations that were developed to determine the critical erosive shear stress needing to be exceeded for flow-induced erosion to take effect. The rate of erosion is mainly enhanced by the formation of an initial breach or notch, which further leads to the development of localized shear stress that intensifies the enlargement of the initial breach. The development of the breach under continuous hydraulic action is directly proportional to the rate of erosion of the dam materials. This is consistent with the pioneering works of Simmler and Samet (1982), who concluded that during the overtopping of a dam, erosion of the downstream slope is initiated once the flow rate over the dam reaches a critical value. This value is a function of several factors, which include the downstream slope angle, the degree of compaction, and grain size.

Most physical models of overtopping failure of earthfill and landslide

Table 5

Summary of selected literature on physical modelling of overtopping failure of earthfill and landslide dams.

\begin{tabular}{|c|c|c|c|c|}
\hline Material(s) & $\begin{array}{l}\text { Simulated Failure } \\
\text { Mechanism(s) }\end{array}$ & $\begin{array}{l}\text { Experimental } \\
\text { Apparatus }\end{array}$ & Major Findings & Reference \\
\hline Sand and gravel & Overtopping* & $\begin{array}{l}\text { Rectangular flume } \\
\text { tank }\end{array}$ & $\begin{array}{l}\text { The primary erosion mechanisms of the non-cohesive homogeneous embankments } \\
\text { comprise tractive shear and turbulence. The erosion process was mostly vertical to } \\
\text { lateral, with an hourglass-shaped breach channel. }\end{array}$ & $\begin{array}{l}\text { Coleman et al. } \\
(2002)\end{array}$ \\
\hline Sand-clay mixtures & Overtopping & $\begin{array}{l}\text { Rectangular flume } \\
\text { tank }\end{array}$ & Peak outflow has a positive correlation with breach deformation time. & $\begin{array}{l}\text { Chinnarasri et al. } \\
\text { (2004) }\end{array}$ \\
\hline $\begin{array}{l}\text { Cohesive } \\
\text { homogeneous } \\
\text { material }\end{array}$ & Overtopping* & $\begin{array}{l}\text { Large-scale (out- } \\
\text { door) flume }\end{array}$ & $\begin{array}{l}\text { Observed a four-phase breaching process of cohesive embankments. Headcut } \\
\text { migration rate and breach widening rate significantly influenced the breach } \\
\text { parameters and the peak discharge. }\end{array}$ & $\begin{array}{l}\text { Hanson et al. } \\
(2005)\end{array}$ \\
\hline $\begin{array}{l}\text { Cohesive } \\
\text { homogeneous } \\
\text { material }\end{array}$ & Overtopping* & $\begin{array}{l}\text { Large-scale (out- } \\
\text { door) flume }\end{array}$ & $\begin{array}{l}\text { Breach widening process in cohesive embankments is controlled by the } \\
\text { compaction characteristics of the soil. }\end{array}$ & Hunt et al. (2005) \\
\hline $\begin{array}{l}\text { Gravel and sand- } \\
\text { gravel mixtures }\end{array}$ & Overtopping & $\begin{array}{l}\text { Rectangular flume } \\
\text { tank }\end{array}$ & $\begin{array}{l}\text { Determined the peak discharge for a prototype dam. Used similarity rule to } \\
\text { compute peak discharge. }\end{array}$ & $\begin{array}{l}\text { Dupont et al. } \\
(2007)\end{array}$ \\
\hline Soil & Overtopping & $\begin{array}{l}\text { Rectangular flume } \\
\text { tank }\end{array}$ & $\begin{array}{l}\text { The development of the breach channel depends on the upstream lake discharge, } \\
\text { riverbed morphology, and grain size distribution. }\end{array}$ & Yan et al. (2009) \\
\hline $\begin{array}{l}\text { Uniform noncohesive } \\
\text { sediment }\end{array}$ & $\begin{array}{l}\text { Overtopping and } \\
\text { sliding }\end{array}$ & $\begin{array}{l}\text { Rectangular flume } \\
\text { tank }\end{array}$ & $\begin{array}{l}\text { Overtopping-induced breach development occurred with an increase in inflow } \\
\text { discharge and decrease in dam height. Sliding was dominant in dams comprised of } \\
\text { coarse material due to an increase in dam saturation. }\end{array}$ & $\begin{array}{l}\text { Schmocker and } \\
\text { Hager (2012) }\end{array}$ \\
\hline Cohesive soils & Overtopping & $\begin{array}{l}\text { Large-scale (out- } \\
\text { door) flume }\end{array}$ & $\begin{array}{l}\text { The breach evolution process, including the peak discharge and the final breach } \\
\text { geometry depends on the shear strength properties of the dam material. }\end{array}$ & $\begin{array}{l}\text { Zhang et al. } \\
\text { (2009a) }\end{array}$ \\
\hline Gravel & $\begin{array}{l}\text { Overtopping/ } \\
\text { headcutting/sliding }\end{array}$ & $\begin{array}{l}\text { Rectangular flume } \\
\text { tank }\end{array}$ & $\begin{array}{l}\text { Observed three (3) dominant typologies of dam failure (overtopping, headcutting } \\
\text { and a combination of instability and headcutting), which mostly depends on the } \\
\text { dam material, downstream slope and bed slope angles. }\end{array}$ & $\begin{array}{l}\text { Gregoretti et al. } \\
\text { (2010) }\end{array}$ \\
\hline $\begin{array}{l}\text { Sand-clay-gravel } \\
\text { mixtures }\end{array}$ & Overtopping* & $\begin{array}{l}\text { Rectangular flume } \\
\text { tank }\end{array}$ & $\begin{array}{l}\text { Initial notch, inflow discharge and soil properties influenced the dam breaching } \\
\text { process. }\end{array}$ & Cao et al. (2011) \\
\hline $\begin{array}{l}\text { Sand-silt-clay } \\
\text { mixtures }\end{array}$ & Overtopping & $\begin{array}{l}\text { Rectangular flume } \\
\text { tank }\end{array}$ & $\begin{array}{l}\text { Headcut erosion plays a significant role in the breaching process of dams } \\
\text { comprised of cohesive materials. The rate of erosion was controlled by the } \\
\text { percentage of clay in the soil mixtures. }\end{array}$ & (Zhu et al., 2011) \\
\hline Sand and coal & Overtopping* & $\begin{array}{l}\text { Rectangular flume } \\
\text { tank }\end{array}$ & $\begin{array}{l}\text { The evolution of breach channel depends on the reservoir water level, discharge } \\
\text { and physical properties of the dam materials. }\end{array}$ & Yu et al. (2013) \\
\hline $\begin{array}{l}\text { Commercial sand and } \\
\text { kaolin clay }\end{array}$ & Overtopping & $\begin{array}{l}\text { Rectangular flume } \\
\text { tank }\end{array}$ & $\begin{array}{l}\text { Soil properties have a major effect on the evolution of the breach parameters and } \\
\text { migration of the headcut. }\end{array}$ & $\begin{array}{l}\text { Cestero et al. } \\
\text { (2015) }\end{array}$ \\
\hline Homogeneous soil & Overtopping & $\begin{array}{l}\text { Large-scale (out- } \\
\text { door) flume }\end{array}$ & Identified four (4) stages of overtopping-induced breaching of levees. & $\begin{array}{l}\text { Kakinuma and } \\
\text { Shimizu (2014) }\end{array}$ \\
\hline $\begin{array}{l}\text { Heterogeneous sand } \\
\text { mixtures }\end{array}$ & $\begin{array}{l}\text { Overtopping and } \\
\text { sliding }\end{array}$ & $\begin{array}{l}\text { Rectangular flume } \\
\text { tank }\end{array}$ & $\begin{array}{l}\text { The longevity of the dams was influenced by the riverbed morphology, hydraulic } \\
\text { conductivity and antecedent moisture content. }\end{array}$ & Chen et al. (2015a) \\
\hline Beach sand & Overtopping* & $\begin{array}{l}\text { Rectangular flume } \\
\text { tank }\end{array}$ & Peak discharge varied linearly with initial dam height. & $\begin{array}{l}\text { Walder et al. } \\
\text { (2015) }\end{array}$ \\
\hline $\begin{array}{l}\text { Noncohesive uniform } \\
\text { sand }\end{array}$ & Overtopping* & $\begin{array}{l}\text { Rectangular flume } \\
\text { tank }\end{array}$ & $\begin{array}{l}\text { The evolution of the breach profiles depends on the inflow discharge and the } \\
\text { downstream boundary conditions. }\end{array}$ & Rifai et al. (2017) \\
\hline Fairly uniform sand & Overtopping & $\begin{array}{l}\text { Rectangular flume } \\
\text { tank }\end{array}$ & $\begin{array}{l}\text { The temporal evolution of the embankments was controlled by two major } \\
\text { processes: wave-induced sediment transport and bank collapse under drawdown } \\
\text { condition. }\end{array}$ & Cristo et al. (2017) \\
\hline Copper tailings & Overtopping & $\begin{array}{l}\text { Rectangular flume } \\
\text { tank }\end{array}$ & $\begin{array}{l}\text { The evolution of the breach profile was controlled by the number of reinforcement } \\
\text { layers in the dam. }\end{array}$ & Jing et al. (2019) \\
\hline Tailings material & Overtopping & $\begin{array}{l}\text { Centrifuge model } \\
\text { test }\end{array}$ & $\begin{array}{l}\text { Dam breach occurred by a combination of continuous downcutting and lateral } \\
\text { expansion of the breach channel. }\end{array}$ & Deng et al. (2019) \\
\hline
\end{tabular}

Overtopping* = overtopping with an initial breach (or notch) on the dam crest 
Table 6

Selected literature on experimental study of dam failure by internal erosion, seepage and piping

\begin{tabular}{|c|c|c|c|c|}
\hline Material(s) & $\begin{array}{l}\text { Simulated Failure } \\
\text { Mechanism(s) }\end{array}$ & Experimental Apparatus & Major Findings & Reference \\
\hline Glass beads & Piping & Rigid-wall permeameter & $\begin{array}{l}\text { Susceptibility of a soil-filter system to piping is mostly dependent on the } \\
\text { grain-size ratio. }\end{array}$ & $\begin{array}{l}\text { Tomlinson and Vaid } \\
\text { (2000) }\end{array}$ \\
\hline Embankment material & Internal erosion & $\begin{array}{l}\text { Pinhole test and } \\
\text { miniature resistivity } \\
\text { array }\end{array}$ & High resistivity values correlate with the development of piping hole. & Burns et al. (2006) \\
\hline $\begin{array}{l}\text { Sand - Coir fiber } \\
\text { mixtures }\end{array}$ & $\begin{array}{l}\text { Seepage and } \\
\text { piping }\end{array}$ & Rigid-wall permeameter & Piping resistance increased with an increased fiber content. & $\begin{array}{l}\text { Sivakumar Babu and } \\
\text { Vasudevan (2008) }\end{array}$ \\
\hline $\begin{array}{l}\text { Uniform fine poorly- } \\
\text { graded sand }\end{array}$ & Piping & $\begin{array}{l}\text { True triaxial piping test } \\
\text { apparatus (TTPTA) }\end{array}$ & $\begin{array}{l}\text { Developed a new experimental apparatus which can measure seepage flow } \\
\text { in either vertical or horizontal directions. }\end{array}$ & $\begin{array}{l}\text { Richards and Reddy } \\
\text { (2010) }\end{array}$ \\
\hline Fly ash and geofiber & Piping & Rigid-wall permeameter & $\begin{array}{l}\text { Optimum improvement in piping resistance was achieved with fiber } \\
\text { content of } 0.05 \% \text { and fiber length of } 50 \mathrm{~mm} \text {. }\end{array}$ & Das et al. (2009) \\
\hline $\begin{array}{l}\text { Loess-derived soil } \\
\text { horizon }\end{array}$ & Piping & Laboratory pinhole test & $\begin{array}{l}\text { Pipeflow discharge and sediment discharge increased with an increase in } \\
\text { hydraulic head. }\end{array}$ & $\begin{array}{l}\text { Nadal-Romero et al. } \\
\text { (2011) }\end{array}$ \\
\hline Earthfill materials & Internal erosion & Rigid-wall permeameter & $\begin{array}{l}\text { Suffusion is characterized by the episodic migration of fines. The onset of } \\
\text { internal instability is controlled by hydraulic gradient and effective stress. }\end{array}$ & Moffat et al. (2011) \\
\hline $\begin{array}{l}\text { Commercial sand and } \\
\text { crushed granite }\end{array}$ & Internal erosion & $\begin{array}{l}\text { Stress-controlled erosion } \\
\text { apparatus }\end{array}$ & $\begin{array}{l}\text { Proposed three critical hydraulic gradients: initiation, skeletal- } \\
\text { deformation and failure. }\end{array}$ & $\begin{array}{l}\text { Chang and Zhang } \\
\text { (2013) }\end{array}$ \\
\hline Silica sand mixtures & Internal erosion & Rigid-wall permeameter & $\begin{array}{l}\text { Critical hydraulic gradients for internal erosion have a positive correlation } \\
\text { with fines content and relative density. }\end{array}$ & $\begin{array}{l}\text { Ke and Takahashi } \\
\text { (2012a) }\end{array}$ \\
\hline Cohesionless sand & Piping & $\begin{array}{l}\text { Stress-controlled erosion } \\
\text { apparatus }\end{array}$ & $\begin{array}{l}\text { Resistance to piping was affected by soil gradation, particle angularity and } \\
\text { specific gravity. }\end{array}$ & $\begin{array}{l}\text { Fleshman and Rice } \\
\text { (2014) }\end{array}$ \\
\hline $\begin{array}{l}\text { Dry Creek and Cow Creek } \\
\text { soils }\end{array}$ & $\begin{array}{l}\text { Internal erosion } \\
\text { and piping }\end{array}$ & $\begin{array}{l}\text { Flume box and } \\
\text { laboratory mini-JET }\end{array}$ & $\begin{array}{l}\text { The physical properties of the soil (e.g., dry density, clay content, } \\
\text { plasticity, moisture content, etc.) have a major influence on the } \\
\text { development of internal erosion and piping. }\end{array}$ & Fox et al. (2013) \\
\hline $\begin{array}{l}\text { Sand-clay and sand- } \\
\text { gravel mixtures }\end{array}$ & Suffusion & Triaxial erodimeter & $\begin{array}{l}\text { Global backward erosion which is linked with a decrease in the specimen } \\
\text { diameter. }\end{array}$ & Marot et al. (2016) \\
\hline Silica sand mixtures & $\begin{array}{l}\text { Seepage and } \\
\text { piping }\end{array}$ & Rectangular flume tank & $\begin{array}{l}\text { Identified five breach evolution processes: pipe evolution, pipe } \\
\text { enlargement, crest settlement, hydraulic fracturing, and sloughing. }\end{array}$ & $\begin{array}{l}\text { Okeke and Wang } \\
(2016 a)\end{array}$ \\
\hline $\begin{array}{l}\text { Silica sands and gravel } \\
\text { mixtures }\end{array}$ & Seepage & Rectangular flume tank & $\begin{array}{l}\text { Critical seepage velocity for dam failure has a positive correlation with } \\
\text { dam height, dam crest width, pore geometry, upstream discharge and } \\
\text { antecedent moisture content. }\end{array}$ & $\begin{array}{l}\text { Okeke and Wang } \\
\text { (2016b) }\end{array}$ \\
\hline Sand-gravel mixture & Piping & Rectangular flume tank & $\begin{array}{l}\text { Critical hydraulic gradient for piping depends on the thickness of the } \\
\text { overlying clay layer. }\end{array}$ & Wang et al. (2016c) \\
\hline Yangtze River beach sand & Piping & $\begin{array}{l}\text { Stress-controlled } \\
\text { permeameter }\end{array}$ & $\begin{array}{l}\text { The critical hydraulic gradient for piping is positively correlated with the } \\
\text { effective mean stress and the deviatoric stress. }\end{array}$ & Liang et al. (2017) \\
\hline Sand-gravel mixtures & Suffusion & Triaxial erodimeter & $\begin{array}{l}\text { Concluded that the critical hydraulic gradient for suffusion is controlled by } \\
\text { the hydraulic loading history. }\end{array}$ & Rochim et al. (2017) \\
\hline $\begin{array}{l}\text { Fu-Long beach sand and } \\
\text { uniform quartz sand }\end{array}$ & Piping & $\begin{array}{l}\text { Stress-controlled } \\
\text { permeameter }\end{array}$ & $\begin{array}{l}\text { Observed that the average critical hydraulic gradients }(0.98 \text { and } 1.01) \text { of } \\
\text { the soils were close to that of Terzaghi's theoretical value. }\end{array}$ & $\begin{array}{l}\text { Yang and Wang } \\
(2017)\end{array}$ \\
\hline Landslide material & $\begin{array}{l}\text { Seepage and } \\
\text { piping }\end{array}$ & $\begin{array}{l}\text { Large-scale (out-door) } \\
\text { flume }\end{array}$ & $\begin{array}{l}\text { Found a linear relationship between the turbidity of the effluent seepage } \\
\text { and settlement of the dam crest. }\end{array}$ & Wang et al. (2018a) \\
\hline Silica sand mixtures & Seepage & Rectangular flume tank & $\begin{array}{l}\text { Soil properties played an influential role on the breaching process of the } \\
\text { landslide dams. Sliding was the major failure mode of the dam models } \\
\text { under steady state seepage loading. }\end{array}$ & Xiong et al. (2018) \\
\hline
\end{tabular}

dams have been carried out using different-sized rectangular flume tanks (see Table 5) (; Cao et al., 2011; Hancox et al., 2005; Macchione and Sirangelo, 1988; Schmocker and Hager, 2012; Simmler and Samet, 1982). A review of the literature on physical modelling of dams shows that the most significant parameters contributing to the overtopping failure of dams are the degree of compaction, grain-size distribution, and antecedent moisture content (Cao et al., 2011; Cestero et al., 2015; Chen et al., 2015a; Hunt et al., 2005; Zhang et al., 2009a). Simmler and Samet (1982) performed a series of physical model tests to investigate overtopping-induced failure of earthfill dams. The authors report that the erosion process is influenced by the geometry and type of the material composing the dam, including the reservoir volume and the location of the impervious material. Hunt et al. (2005) performed a series of large-scale (outdoor) physical experiments to evaluate the rate of breach widening in dams constructed of cohesive homogeneous materials. The authors observed that the rate of breach widening decreased with an increase in compaction water content.

Similarly, Hanson et al. (2005) investigated the mechanisms of breach formation during overtopping-induced failure of dams constructed of cohesive materials. They found that several physical properties of the soil (clay content, compaction energy, compaction water content, and plasticity index) had a significant effect on the peak discharge, breach widening rate and headcut migration rate. Zhang et al. (2009a) and Cestero et al. (2015) came to similar conclusions.

Little is known about the influence of initial breach geometry on breach development and peak discharge. According to Singh (2013), the initial breach is generally V-shaped (triangular). However, some researchers have investigated overtopping failure of dams by using rectangular or triangular notches of diverse geometries to initiate the breaching process (Rifai et al., 2017; Walder et al., 2015; Yu et al., 2013). For instance, Coleman et al. (2002) found that the primary erosion mechanisms of the dams (constructed of non-cohesive, homogeneous materials) were by tractive shear and turbulence. Cao et al. (2011) used a trapezoidal notch of varying depths to investigate the overtopping erosion of natural dams comprised of non-cohesive sand, sand and cohesive clay, and a mixture of sand and gravel. They found that lower peak discharge occurred and that floods in the downstream arrived sooner in dams with than in those without an initial breach. However, changes in initial breach geometry, as well as in grain-size distribution, make a direct comparison between these studies challenging.

\subsubsection{Internal erosion, seepage and piping}

Internal erosion involves the movement of water through a continuous crack or defect within a compacted fill, foundation, or at their contact between. According to Dunne (1990) and Bryan and Jones 
(1997), the three major conditions governing the occurrence of seepage and internal erosion in soils are: (1) the evolution of pore-water pressure and its effects on the shear strength of the soil, (2) the development of sufficient drag force that entrains materials in water seeping through and out of a porous medium, resulting in liquefaction or Coulomb failure, and (3) the gradual evolution of macro-pores. The formation of a piping hole at the exit face of a dam has been attributed to hydraulic gradients high enough to cause internal instability in the soil. This development accentuates subsequent entrainment and erosion at the periphery of the piping hole, leading to its enlargement (Fell and Fry, 2013; Okeke and Wang, 2016a). Erodibility is an important parameter for evaluating the stability of dams. Field and laboratory investigations conducted by Wan and Fell (2004), Hanson et al. (2010), and Chang et al. (2011) found that the erodibility coefficient was inversely proportional to the degree of compaction, in addition to other factors such as plasticity index, clay content, degree of saturation, moisture content, and dispersivity. Soil erosion parameters are commonly evaluated using the hole erosion test (HET), and the slot erosion test (SET). Benahmed and Bonelli (2012) performed HET tests on cohesive soils to determine the critical shear stress and the erodibility coefficient. They found that critical shear stress increases with an increase in dry density and clay content, but decreases as water content increases.

In contrast to experiments on overtopping that primarily utilize flume tanks, research of internal erosion and piping use a wider range of experimental devices, including triaxial erodimeter, rigid-wall permeameter, rectangular flume tank, stress-controlled permeameter, laboratory pinhole test, and mini-JET apparatus (Table 6). One of the most notable contributions to the understanding of internal erosion and piping failure of earthfill dams was the intermediate report of the European Working Group on Internal Erosion in Embankment Dams (EWGIE). Many of the studies from this group (Fell and Fry, 2013) provide detailed experimental approaches and discussions on the hydraulic criteria for internal erosion and piping in dams comprised of cohesive and non-cohesive materials. The critical hydraulic gradient and the critical seepage velocity for the initiation of internal erosion and piping are two essential criteria for evaluating dam stability. Laboratory evaluations of these hydraulic parameters in soils have been achieved by measuring one-dimensional seepage flow using a rigid-wall cylindrical permeameter (Ke and Takahashi, 2012a; Kokusho and Fujikura, 2008). A major disadvantage of using the rigid-wall permeameter is the inability to evaluate the stress states of soils subjected to internal erosion. Consequently, several researchers (Bendahmane et al., 2008; Ke and Takahashi, 2012b; Moffat and Fannin, 2011) developed new experimental techniques that comprise either a modified rigid-wall permeameter cell with axial loading systems or a stress-controlled testing apparatus (triaxial erodimeter). For instance, Chang and Zhang (2013) used a stress-controlled internal erosion testing apparatus to investigate the initiation mechanism of internal erosion in gap-graded soils under complex stress states. The authors defined three critical hydraulic gradients based on four stages of internal erosion. They concluded that the pore system of the soil influenced the initiation hydraulic gradient, whereas the soil shear strength, seepage pressure, and the initial stress conditions control the failure hydraulic gradient.

\subsubsection{Summary and outlook}

One of the major challenges of physical modelling of earthfill and landslide dam failures is the adoption of a representative scale that can reproduce the forms and processes in the model. The reliability of the results obtained from physical modelling depends on the accuracy of the model in accordance with the laws of hydraulic similarity. The three factors that are usually considered in physical modelling of fluvial processes are: (1) the type of material (shape, particle density and diameter, and grading), (2) fluid characteristics (density and viscosity), and (3) the kind of flow (flow depth, bed slope, and acceleration due to gravity) (Young and Warburton, 1996). Future research would benefit from systematic parameter studies and from studies that systematically increase the complexity of the dam materials. Combined numericalphysical approaches (including 3D numerical models) would add valuable insights and synergies.

\subsection{Numerical modelling}

In recent decades, numerical-modelling-based computer simulation tools were widely developed and used to predict the behaviour of natural geological processes. Numerical modelling of landslide dams relies heavily on the input data of the landslide geometry, internal structure and properties of landslide bodies obtained from remote sensing, geophysical and geotechnical assessments (discussed above). Herein, we provide an overview of recent studies that use numerical models to (1) reconstruct landslide dams in $2 \mathrm{D}$ and $3 \mathrm{D},(2)$ investigate stability criteria of landslide dams, (3) model dam-breach, and (4) model dam-breachinduced flooding.

\subsubsection{Modelling landslide dam formation and predicting dam geometry}

The first application of numerical modelling for landslide dam studies is simulating the formation of the dam itself. There are two aims in this approach: firstly, to model the probability of landslide dam formation, and secondly, to reconstruct the geometry of landslide dams in 2D and 3D. Most of the numerical modelling programs that can model landslide runout (Rickenmann, 2005) can be used to predict/estimate whether or not a landslide will reach a nearby river and therefore form a dam. There are diverse numerical methods and programs for this purpose (Beguería et al., 2009; Crosta et al., 2003; Crosta et al., 2006; Crosta et al., 2007; Crosta et al., 2009; Crosta et al., 2010; Hungr, 1995; Sassa et al., 2010; Takahashi, 1988; Van Asch et al., 2014; Van Tien et al., 2018). A recent comprehensive review of landslide runout modelling by (Fan et al., 2019a) details these approaches.

Hungr (2011) examined the possibility of predicting landslide dam geometry using empirical, 2D and 3D dynamic analyses of landslide runout. Using several landslide case studies, the authors demonstrated the applicability of dynamic landslide motion to analyse the formation of a dam. As an example, the $1987 \mathrm{Val}$ Pola rockslide in Northern Italy was simulated using both, the 2D and 3D models DAN and DAN3D, respectively (Hungr, 2011). Using Bingham, Voellmy, and frictional rheologies in the 2D DAN model, the runout distance and height of the landslide dam were successfully predicted. Frictional rheology was used in the DAN3D model, and agreeable results were obtained. This study is so far the only comparative study on the use of landslide runout models to predict landslide dam geometries. Recently, Van Tien et al. (2018) analysed the formation process of two massive dams following rainfallinduced deep-seated rapid landslide failures in the Kii Peninsula of Japan using an integrated model to simulate the initiation and motion of landslides (LS-RAPID) as proposed by Sassa et al. (2010).

\subsubsection{Modelling and prediction of landslide dam stability}

Numerical modelling can aid in predicting dam breach and subsequent failure in situations where practical engineering judgments need to be made. Another aspect of modelling landslide dam stability is analysing the stability of the slopes of a landslide dam (Awal et al., 2007, 2008a,b, 2009). In such cases, half of the landslide dam (slope body) will lie under water, and the remainder will lie above water level. Few studies exist that model both, the unsaturated and saturated areas of landslide dams simultaneously (Regmi et al., 2010; Regmi et al., 2013).

Chen et al. (2015b) presented a dam breaching/stability model based on Excel 2007, and later developed the DBS-IWHR code with Wang et al. (2016b), in which slope failure during dam breaching is considered by the simplified Bishop method. Cao et al. (2011) presented a coupled 2D mathematical model based on shallow water hydrodynamic equations to simulate landslide dam failure. The dam breaching process is simulated as the interaction of sediment transport and slope failure. The model was tested against laboratory analysis of uniform model dams. However, the models for artificial dams do not normally consider the highly 
heterogeneous distribution of soil materials, which leads to dynamically varied erosion rates during dam breaching. The authors therefore conclude that sufficient data must be available to refine the models for the application to landslide dams.

\subsubsection{Modelling the breach: erosion and overtopping of landslide dams}

Numerous models are available for simulating dam breaching of embankment dams (ASCE/EWRI, 2011; Zhang et al., 2016), and the majority of numerical models available for modelling landslide dam failure processes focus on breach by overtopping (Braun et al., 2018; Capart, 2013; Chen et al., 2004; Chinnarasri et al., 2004; Coleman et al., 2002; Evans, 1986; Fan et al., 2012a; Fan et al., 2012b; Fread, 1988; Jinchi, 2008; Liu et al., 2012; Peng and Zhang, 2012b; Plaza et al., 2011; Shi et al., 2015; Wahl, 1997; Wahl, 2004; Zhang et al., 2009a; Zhang et al., 2019a; Yue et al., 2008). One of the most widely used is BREACH developed by Fread (1984, 1988, 1996, 2014). The BREACH model was used to estimate dam-breach probability of, e.g. the Hsiaolin village landslide dam (Dong et al., 2011a; Li et al., 2011; Lo et al., 2011) and the Tangjiashan landslide dam (Fan et al., 2012a; Liu et al., 2012; Wang et al., 2015). Recently, EMBREA, another evolution of a breach model named HR-BREACH originally made for manmade embankments, was improved to be used for natural/landslide dams (Davison et al., 2013; Lumbroso et al., 2020; Morris et al., 2018; Morris et al., 2020; Morris, 2013; Ríha et al., 2020; Zhu et al., 2019).

Another common and widely used dam-breach model is DABA, a physically-based numerical simulation tool (Chang and Zhang, 2010). The model can consider breach evolution, sediment erosion, variation of soil properties with depth, and can predict the outflowing flood hydrograph. Seepage flow of lake water through the dam is simulated by the hydrodynamic model using the broad-crested weir flow equation. It is assumed that the cross-section of the landslide dam is trapezoidal and the overall slope is changing at a constant rate. The key parameters, including final dam-breach dimensions, the timing of the breach and peak flow, are the typical model outputs. DABA also considers the variation of soil erodibility with depth. Several studies used the DABA model to simulate dam-breach; examples include the Tangjiashan landslide dam and Xiaogangjian landslide dam caused by the Wenchuan earthquake, in which the results were in good agreement with observed measurements (Peng et al., 2014; Peng, 2012; Shi et al., 2015). Shi et al. (2015) improved the DABA model to simulate the cascading breaching of several landslide dams in a series with some modifications on the time-related inflow rates and simultaneous erosion both in breach and on dam crest. With the improved DABA model, the cascading breaching of the Tangjiashan and two smaller downstream landslide dams were simulated, and the critical condition for the overlapping effects of cascading dam breaching were identified. Chen and Zhang (2015) developed a two-dimensional numerical code, EDDA, to simulate the erosion and deposition of soil materials during landslide dam breaching and debris flow evolution. The heterogeneity of soil properties in two dimensions can be considered in cell-based regions. See Zhong et al. (2021) for review on typical empirical and physically-based mathematical models analysing breach of embankment and landslide dams.

\subsubsection{Dam-breach-induced flood modelling}

The final process in the process chain or hazard cascade of landslide dams is modelling dam-breach-induced flooding. For these events, directly coupled models that can model both the initial breach and resulting floods are not yet available (although there do exist coupled hazard models which can model landslides and floods within a catchment simultaneously; e.g. (Awal et al., 2008b; Bout and Jetten, 2018; Bout et al., 2018a, 2018b). In most cases, the breach is addressed separately, and the flood is modeled using the value of peak discharge from the breach model (Fan et al., 2012a, 2019b). The flood-modelling package Hydrologic Engineering Center River Analysis System (HECRAS) is used for this purpose (Brunner, 1995; Brunner, 2002). HEC-RAS, a one-dimensional predictive model, is one of the simplest dam-break programs. It only requires the terrain cross-sections perpendicular to the direction of flow for computing average water depth and flow velocity. Several studies have also modeled the dam-breach-induced flood using traditional flood routing models (Cao et al., 2011; Capart, 2013; Davies et al., 2007; De Roo et al., 2000; Fan et al., 2012a; Fread, 1984, 1996; Glancy and Bell, 2000; Hewitt, 1982; Manville, 2001; Morche and Schmidt, 2012; Peng and Zhang, 2012c; Risley et al., 2006; Sandrp, 2018; Satofuka et al., 2010; Sun et al., 2014; Tabata, 2001; Van Der Knijff et al., 2010; Walder and O'Connor, 1997; Xu et al., 2012; Yan et al., 2009; Zhu et al., 2012).

\subsubsection{Numerical modelling of other landslide-dam-related phenomena}

In addition to landslide runout, dam stability, dam breach, and dambreach-induced flood modelling, other geomorphic processes exist where numerical modelling can be applied. Modelling the impact of landslides into a landslide-dammed lake, landslide-induced surge wave and its overtopping of a dam, and their effects on dam stability are also common (Cui and Zhu, 2011; Lin et al., 2015; Liu et al., 2018). This kind of modelling is similar to river-water tsunami simulation, and a few studies report their significance and processes for landslide dam studies (Assier-Rzadkieaicz et al., 2000; Hermanns et al., 2013b; Ward and Day, 2011). Studies that deal with river-water tsunamis in an artificially dammed river are more common than landslide-dammed rivers (Bardet et al., 2003). Different types of modelling are performed for debris flows induced by a landslide dam breach (Chen et al., 2004; Cui et al., 2013).

\subsubsection{Summary and outlook}

Each numerical model has particular advantages and disadvantages. Starting from the landslide runout and resulting deposit/dam thickness (Fig. 8) to the dam-breach-induced flood modelling, the scarcities in the input parameters are the primary disadvantage where material characterization is paramount. Both, the strength and the limitation of numerical models arise from the availability of data, such as rock mass strength parameters, runout parameters, landslide dam material parameters, etc. If sufficient characterization of the soil/rock or dam parameters is available, all the numerical methods summarized in Table 7 can provide meaningful results.

Some problems, however, remain unsolved:

(1) The heterogeneity of soil property distribution is not sufficiently considered. Landslide dams form by the quick deposition of landslides. A three-dimensional dam model incorporating spatial heterogeneity is needed to effectively simulate the complex breaching process of landslide dams.

(2) Both erosion and deposition need to be considered. Eroded soil and rock materials deposited regularly along the river close to landslide dams can have a large influence the hydrogeological environment. Whilst much attention is given to erosion processes, similar importance to deposition processes should also be given.

(3). Loss of fines due to internal erosion and variations in water content due to seepage have a significant effect on permeability and erodibility of dam materials. Consideration of the influence of seepage and internal erosion on erodibility of dam materials is required.

(4) The influence of boulders on the breaching of landslide dams. Boulders are frequently observed on top of, and sometimes inside of, landslide dams. Modelling the complex interactions between water flows at different scales between small soil particles and large boulders remains an outstanding challenge.

Landsliding into a river creates a process chain inducing individual hazards, i.e. dam breach, river tsunami, dam-breach-induced floods, and debris flows. Present models consider these hazards separately and can only model them as individual processes and until recently, the idea of numerically modelling an entire process chain has not been considered. However, studies aiming to numerically model entire landslide-induced hazard cascades are gaining traction in recent years (Bout and Jetten, 2018; Bout et al., 2018a, 2018b; Fan et al., 2019c). A single numerical model to model the entire process chain from landslide initiation to 
dam-breach flood is still an outstanding goal of future numerical modelling approaches.

\section{Discussion}

The formation of potentially unstable landslide dams is part of a hazard cascade starting with the landslide itself, flooding upstream of the blockage, and potentially catastrophic outburst floods downstream. This paper is a contribution towards understanding these phenomena by providing a comprehensive review of the state-of-the-art in dam investigation and analyses-ranging from remote sensing, dating, geophysical methods, sedimentology and geotechnical properties to laboratory analogue and numerical modeling. We conclude our review with examples of combined applications of the presented methods.

\subsection{Dam dimensions, distributions, and timelines (remote sensing,} geophysics, dating, sedimentology)

Advances in remote sensing technology and increased commercial availability of their products has led to more widespread identification of landslide dams in recent decades. These provide a good basis for robust statistical analyses of dam distribution and dimensions. The first inventory studies utilizing remote sensing, i.e. historical aerial photographs, were conducted by Korup (2005a, b). Since then, satellite image interpretations were used for landslide dam recognition and for the creation of inventories (e.g. Tacconi Stefanelli et al., 2015, 2016, 2018). Often, dam inventories are created through visual interpretation of landslide source and deposition zones by comparing pre- and posttriggering event false-color composites or panchromatic images. For example, Fan et al. (2012b) created an inventory comprising 828 landslide dams induced by the 2008 Wenchuan earthquake in China by visual interpretation of satellite and aerial images, including ASTER, ALOS AVNIR-2, ALOS PRISM, Cartosat-1, SPOT-5, and IKONOS data. Investigations on the regional scale typically involve inventory mapping for spatio-temporal studies. These maps can be event-based, which provide the most accurate data in terms of total number of dams identified, good control on geomorphic parameters (such as dam volume from pre- and post-event DEMs), and exact knowledge on the time of

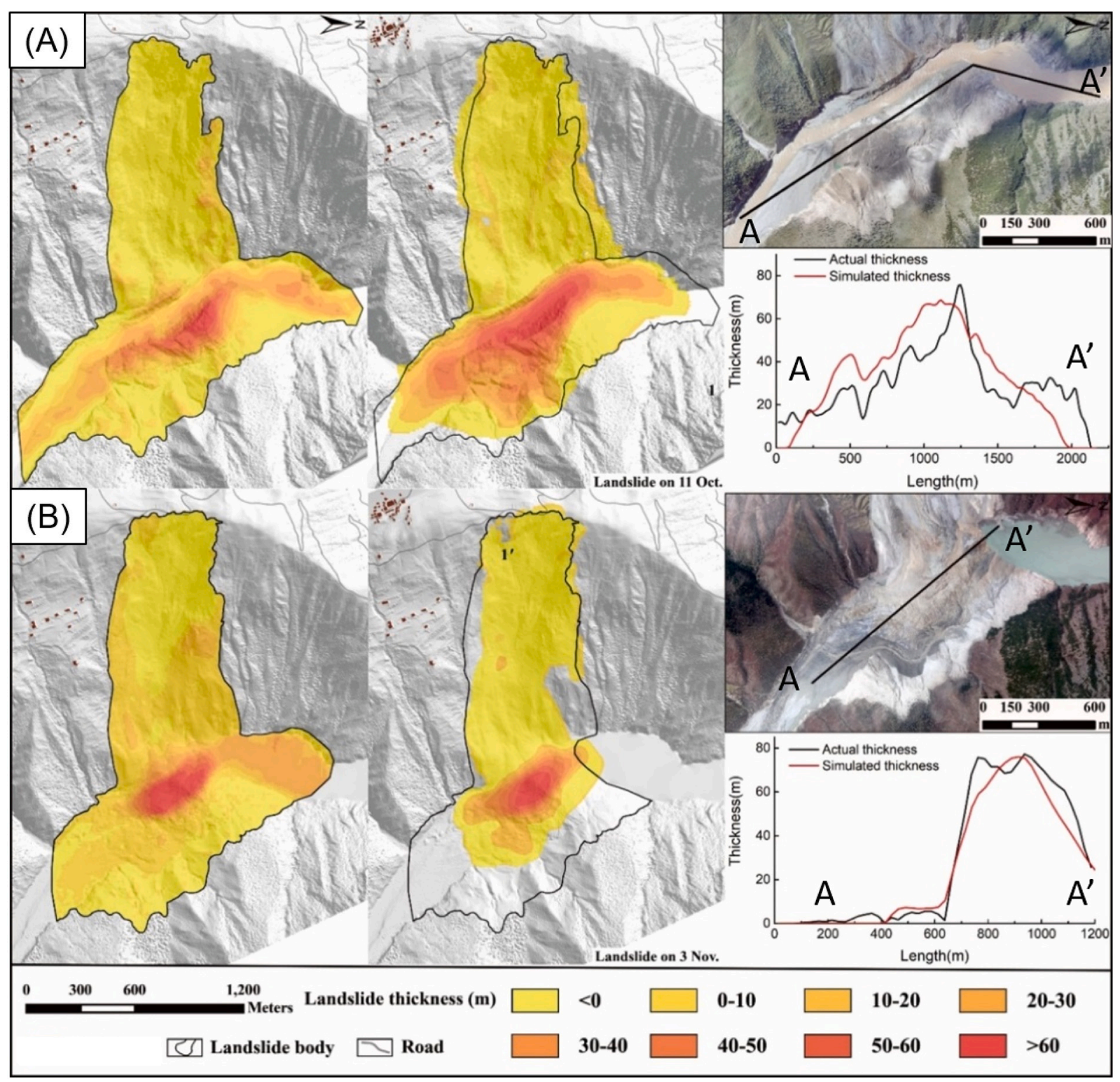

Fig. 8. Example of simulating landslide dam geometry (thickness) using an integrated numerical simulation approach (modified from Fan et al., 2019c): comparisons between measured landslide thickness and numerically simulated landslide thickness for Baige landslide dams occurred on (A) October 11 and (B) November 3. Left: the measured landslide thickness; middle: predicted landslide thickness; and right: comparison of landslide accumulation thickness along the Jinsha River 
dam formation. Very recently, a worldwide inventory and database of 410 landslide dams $>1$ million $\mathrm{m}^{3}$ in volume that were formed since 1900 since was compiled by Fan et al. (2020a).

Adding geophysical studies and dating campaigns to the outcome of remote-sensing studies provides information on, e.g. (i) more exact dam dimensions in $3 \mathrm{D}$, (ii) how often a region or a single site has been affected by river-damming landslides or (iii) whether multiple catastrophic failures with downstream flooding of the same dam have occurred and should be considered in hazard analyses. For example, successful reconstruction of the dimensions of still existing dams were achieved using geophysical methods; e.g. ERT, VES, MASW and SRT surveys at the Scanno Lake landslide dam, Italy (Bianchi-Fasani et al., 2011). At the Lauvitel landslide dam in France, ERT surveys revealed that the dam was part of a much larger rockslide deposit, emplaced over successively smaller rockslides (Delunel et al. (2010) potentially signifying repeated damming. The Las Conchas valley in the Argentinian Andes (NW Argentina) was blocked several times by deposits from the same slope, with two major events dated to $\sim 13.5 \mathrm{ka}$ and $\sim 4.8 \mathrm{ka} \mathrm{BP}$, coinciding with local wet periods. ${ }^{10} \mathrm{Be}$ surface exposure dating of both the rock avalanche deposits and the scarps, and correlation of the obtained ages with the stratigraphy and chronology of adjacent landslidedammed-lake deposits revealed this relationship (Hermanns et al., 2004). This study demonstrates that even dams dating back several thousands of years might be susceptible to failure by overtopping, driven by emplacement of landslide bodies into the landslide-dammed lakes, and that other than seismicity, climatic factors can also control the failure of landslide dams in arid regions.

The longevity of a landslide dam, and its respective lake, is best assessed using multi-method dating to yield the most reliable time constraints-although this approach is still uncommon, mainly because dating is limited by the availability of appropriate geological materials and datable landslide features (Lang et al., 1999). Consequently, relatively few successful multi-dating campaigns exist (e.g. Dong et al., 2014; Hermanns et al., 2004; Moreiras et al., 2015; Ostermann et al., 2017; Prager et al., 2009). One example, the Tschirgant rock avalanche deposit in Austria, was initially dated using a suit of ${ }^{14} \mathrm{C}$ ages and interpreted as being the result of two successive failures at $\sim 3.75$ and 3.15 ka (Patzelt, 2012). Adding ${ }^{36} \mathrm{Cl}$ and $\mathrm{Th} / \mathrm{U}$ dating narrowed the possible time interval of the rock avalanche emplacement to $3.4-2.4 \mathrm{ka}$ BP (Ostermann et al., 2017), with a most probable single-event age of $3.01 \pm 0.1 \mathrm{ka}$ BP. Later IRSL (Infrared Stimulated Luminescence) dating of feldspar in uppermost lacustrine deposits upstream of the dam site returned an age of $2.31 \pm 0.13 \mathrm{ka}$, suggesting that the landslide-dammed lake existed for a few hundred years (Dufresne et al., 2018). Sedimentological and morphological analysis of the up- and downstream landscape can additionally shed light on whether lake drainage was gradual or catastrophic.

\subsection{Dam structures and properties (geophysics, sedimentology, laboratory analogue modeling)}

The internal structure and composition of landslide dams is complex compared to relatively homogeneous, engineered embankment dams. In these artificial dams, the hydrogeological (e.g. seepage flow and fluid pressure) and mechanical characteristics (strength and deformability) of the materials used, as well as the hydrological conditions (e.g. maximum

Table 7

Compilation of different numerical modelling approaches used in landslide dam studies

\begin{tabular}{|c|c|c|c|c|}
\hline Purpose & Methods & Details & Advantages & Disadvantages \\
\hline \multirow[t]{2}{*}{$\begin{array}{l}\text { Landslide } \\
\text { runout }\end{array}$} & Continuum & $\begin{array}{l}\text { Models simulate the moving mass as a two- } \\
\text { dimensional or sometimes three-dimensional } \\
\text { approximation in which the material is assumed } \\
\text { incompressible, and the properties and } \\
\text { kinematics are depth-averaged following the } \\
\text { Saint-Venant's approach. Several models have } \\
\text { been proposed, and implemented in various } \\
\text { software environments. See, for instance, the } \\
\text { works of Beguería et al. (2009); Crosta et al. } \\
\text { (2003); Hungr (1995); Ouyang et al. (2013); } \\
\text { Ouyang et al. (2014); Sassa et al. (2010); } \\
\text { Takahashi et al. (1992); Van Asch et al. (2014); } \\
\text { Van Tien et al. (2018) and their proposed } \\
\text { models. }\end{array}$ & $\begin{array}{l}\text { Runout process simulated through } \\
\text { physically-based laws. The shape of the } \\
\text { deposit can be simulated. }\end{array}$ & $\begin{array}{l}\text { Generally, not specific to landslide dam studies; } \\
\text { usually ignore the multiphasic nature of the } \\
\text { moving mass and the water body of the river; } \\
\text { only the most advanced models can account for } \\
\text { the landslide-bed and river interactions. }\end{array}$ \\
\hline & Discontinuum & $\begin{array}{l}\text { These approaches (both 2D and 3D) simulate the } \\
\text { landslide mass as an assembly of (such as the } \\
\text { discrete element method DEM, and the DDA, } \\
\text { discontinuous deformation analysis). Several } \\
\text { models have been proposed. See, e.g., Cundall } \\
\text { and Strack (1979); Liu et al. (2013); Nian et al. } \\
\text { (2021); Zhao et al. (2017) }\end{array}$ & $\begin{array}{l}\text { Runout process simulated through } \\
\text { physically-based laws treating the } \\
\text { landslide materials as individual shapes } \\
\text { of masses with distinguished properties. }\end{array}$ & $\begin{array}{l}\text { Generally, not specific to landslide dam studies; } \\
\text { several (microscopic) model parameters } \\
\text { without clear physical meaning; calibration of a } \\
\text { large number of parameters are required; only } \\
\text { the most advanced models can account for } \\
\text { solid-fluid coupling. }\end{array}$ \\
\hline \multirow[t]{2}{*}{$\begin{array}{l}\text { Landslide } \\
\text { deposits / } \\
\text { dam } \\
\text { geometry }\end{array}$} & Continuum & $\begin{array}{l}\text { Both two-dimensional and three-dimensional } \\
\text { models, i.e. DAN and DAN3D, respectively ( } \\
\text { Hungr, 2011), can be used. Using Bingham, } \\
\text { Voellmy, and frictional rheologies are possible. }\end{array}$ & $\begin{array}{l}\text { Runout process simulated through } \\
\text { physically-based laws similar to the } \\
\text { landslide runout models. The only } \\
\text { model of this kind. }\end{array}$ & $\begin{array}{l}\text { Usually, ignore the multiphasic nature of the } \\
\text { moving mass and the water body of the river; } \\
\text { only the most advanced models can account for } \\
\text { the landslide-bed and river interactions. }\end{array}$ \\
\hline & Discontinuum & $\begin{array}{l}\text { So far, very few novel studies have attempted ( } \\
\text { Wang et al., 2017; Wang et al., 2019). }\end{array}$ & $\begin{array}{l}\text { Landslide materials are treated as } \\
\text { individual shapes (blocks) of masses } \\
\text { with distinguished properties for solid } \\
\text { and fluid phases. }\end{array}$ & $\begin{array}{l}\text { Consider the multi-phase nature of the moving } \\
\text { mass but block shape assumption for solid } \\
\text { phase materials is far from reality. }\end{array}$ \\
\hline \multirow[t]{2}{*}{ Dam-stability } & Continuum & $\begin{array}{l}\text { Very few studies are reporting a thorough } \\
\text { geotechnical investigation of landslide dam } \\
\text { stability. }\end{array}$ & Simple and explicit. & $\begin{array}{l}\text { Does not account for breaching and erosion } \\
\text { mechanisms. }\end{array}$ \\
\hline & Discontinuum & $\begin{array}{l}\text { So far, no studies have attempted the stability } \\
\text { assessment but analysed the kinematics (Wang } \\
\text { et al., 2017; Wang et al., 2019). }\end{array}$ & $\begin{array}{l}\text { Landslide materials are treated as } \\
\text { individual shapes (blocks) of masses. }\end{array}$ & $\begin{array}{l}\text { Does not account for breaching and erosion } \\
\text { mechanisms. }\end{array}$ \\
\hline \multirow[t]{2}{*}{ Dam-breach } & Continuum & $\begin{array}{l}\text { Few highly cited numerical modelling } \\
\text { approaches to model landslide dam breach }\end{array}$ & $\begin{array}{l}\text { Mostly combined with empirical } \\
\text { methods. Erodibility can be defined. }\end{array}$ & $\begin{array}{l}\text { Heterogeneity of the landslide dam materials is } \\
\text { not accounted. }\end{array}$ \\
\hline & Discontinuum & So far no studies have attempted & - & - \\
\hline $\begin{array}{l}\text { Dam-breach } \\
\text { flood }\end{array}$ & Continuum & HEC-RAS, Mike flood, iRIC etc. & Simple, explicit and diverse models. & Does not account for breaching mechanisms. \\
\hline
\end{tabular}


flood level) are well-constrained, allowing for reliable stability prediction (factor of safety) and lifetime performance of the dam in the design stage. This is commonly assessed using analytical and numerical coupled hydro-mechanical methods. By contrast, landslide dams are typically highly heterogeneous in their internal composition-information that is unknown at formation.

Determining the internal structure of landslide dams, however, plays a key part in the assessment, planning and design of remedial engineering works. To this end, the study of (ancient) breached dams provides insights into the relationships between breach location, dam morphology and properties, albeit in their final, perhaps compacted and altered form, and therefore with a bias toward stable dams. Observations of facies-dependent incision behavior should be viewed in combination with descriptions of the overall debris distribution (i.e., location of the lowest passages; e.g. Usoi, (Hanisch and Söder, 2000)), the relationship between surface morphology and facies (e.g. Dunning et al., 2005), as well as lithological distribution. Debris distribution both, along-valley (Dunning et al., 2005) and across-valley (e.g. Korchevskiy et al., 2011; Strom, 1996; Strom and Korup, 2006), warrants adjustments in dam classifications since it determines the location of lowest freeboard. Likewise, lithological distribution in combination with facies distribution determines erodibility of the dam material. For example, at the giant Köfels and Flims rockslides, the initial spillways were abandoned upon encounter of a larger boulder (Dufresne et al., 2019), respectively at the transition to a more erosion-resistant facies (Wassmer et al., 2004).

Such transitions are expected in dams formed by rock avalanches or rockslides since they typically form a three-facies, layered deposit with an upper coarse carapace above a heterogeneous body, underlain by a (mixed) basal facies (see Dufresne et al., 2016; Dunning and Armitage, 2011; Weidinger et al., 2014 for reviews). A few case studies highlight this. Crosta et al. (2010) collected SRT measurements at the Val Pola rock avalanche dam in Italy identifying three layers in the landslide dam, and providing the shear-wave velocities to estimate material density. Plaza et al. (2011) described how SRT surveys identified horizontal layers in the La Josefina landslide dam, Ecuador, later confirmed during excavations. Wang et al. (2014b) used MT soundings to determine the internal structure of the 781-126 ka Zhanggu landslide dam in Sichuan province, China, identifying a 300-m-deep slip surface. Torgoev et al. (2013) used ERT and H/V measurements on the 'ancient' Ak-kul landslide dam in Kyrgyz Republic to identify zones of saturation and potential weakness within the dam structure (Fig. 9). Wang et al. (2013) used MASW surveys and identified low-velocity zones in landslide dam layers. By combining MASW and MTM methods, Wang et al. (2016a) showed that the internal structure of a landslide dam was relatively undisturbed, but that weathered materials had low resistance to potential dam overtopping.

Hanisch and Söder (2000) hint at a change in dam properties about $140 \mathrm{~m}$ below the level of Lake Sarez behind the Usoi rockslide dam in Tajikistan (see also Strom, 2006, 2014). The occurrence of springs at this level indicates that the lower part of the dam has very low permeability, whereas the upper part is highly permeable, maintaining an average seepage discharge of $45 \mathrm{~m}^{3} / \mathrm{s}$ (Hanisch and Söder, 2000). Data of 1D seismic structure determined by VSP surveys (from survey in 19751977, summarised by Papyrin (2001)), partly assisted the assessment by Ischuk (2011) that the Usoi dam is stable due to its large size.

\subsection{Assessment and monitoring (numerical modeling, geophysics, geotechnical properties)}

Estimating whether a given landslide can form a dam can be based on empirical data and the formulation of thresholds or indices in bi- or multi-variate analyses (cf. Fan et al., 2020 for review) or assessed by numerical modelling. Hungr (2011) examined the possibility of predicting landslide dam geometry using empirical, as well as 2D and 3D dynamic analyses of landslide runout, while other empirical methods to determine the landslide dam height have been proposed and compared to runout modelling (Oppikofer et al., 2020).

In general, however, the hazard assessment of a landslide dam starts after its formation (Alford and Schuster, 2000; Delaney and Evans, 2011; Fan et al., 2012b; Hancox et al., 2005; Plaza-Nieto and Zevallos, 1994), or occasionally when the discharge through long-lasting dams increased (Groeber, 1916). The hazard assessment includes (1) modelling of the flooding upriver of the dam (Clerici and Perego, 2000), (2) dam stability assessment that may include a breach development assessment (e.g. Glicken et al., 1989; Manville, 2001; Meyer et al., 1985), (3) assessment of a potential outburst flood, and (4) occasionally, stability assessment of the slopes surrounding the formed lake (Awal et al., 2007; Awal, 2008; Awal et al., 2008a, b; Awal et al., 2009, 2011; Chen et al., 2015b; Hanisch et al., 2002; Regmi et al., 2010, 2013; Wang et al., 2016b). The last becomes important as displacement waves impacting into landslidedammed lake might trigger displacement waves that overtop and erode the landslide dam catastrophically (Glancy and Bell, 2000; Hermanns et al., 2004; Penna et al., 2008). Wang et al. (2016b) are one of the studies who successfully modelled the lateral enlargement during breach for the Yigong landslide dam using slope stability analysis based on circular slip surface. Further, for landslide dam breach analysis, each numerical model, i.e BREACH, DABA, EDDA, EMBREA, has particular advantages and disadvantages. Though all the above models have been used to successfully predict the dam breach of major landslide dams-i. e. the Tangjiashan landslide dam, the Xiaogangjian landslide dam, Hsiaolin village landslide dam-all the models have their limitations inherent to the simulation mechanisms and input data (Dong et al., 2011a; Li et al., 2011; Liu et al., 2012; Liu et al., 2009; Shi et al., 2015; Wang et al., 2015; Zhong et al., 2021). The same applies to models predicting landslide-dam-breach-induced flooding (Dai et al., 2005; Davies et al., 2007; Fread, 1984; Morche and Schmidt, 2012; Sun et al., 2014; Xu et al., 2012; Zhu et al., 2012). In addition to the general limitations inherent to the model and data, most of the previous studies on landslides, landslide dams, and dam-breach-induced floods mostly focused only on a single type of geomorphic hazard, though in reality all these hazards are inter-connected. The perspective was that the interactions between the different types of hazards are quasi-independent and hence were ignored (Yutao and Shengxie, 2009). To date, the study of Fan et al. (2019c) of the 2018 Baige landslide is the only study that successfully modelled the entire landslide-induced hazard cascade, i.e. landslide runout, river damming, dam breach, and dam-breach-induced flooding, as a single continuum. The key advantage of such a modelling approach is the adaptability for diverse input boundary conditions, allowing the interlinking of one numerical model with another. This, in turn, allowed the successful stability assessment, monitoring and early warning of future hazards during the 2018 Baige landslide event (Fan et al., 2019b, 2019c).

Life loss due to upriver flooding above a landslide dam (Ermini and Casagli, 2002; Kojan and Hutchinson, 1978) urges that dam stability assessment should include this phase of dam formation. This is especially true because extreme weather conditions can trigger multiple landslides simultaneously (e.g. Chigira, 2009; Tsou et al., 2011). During such meteorological conditions, rivers also are at maximum peak discharge and landslide dams can fill up and overtop much faster than during normal annual peak discharges (Hermanns et al., 2013a; Hermanns et al., 2013b). Therefore, landslide dam assessment became an integral part of the analysis of the hazard from unstable rock slopes in Norway (Hermanns et al., 2009; Oppikofer et al., 2016a, 2016b). The concept follows the same idea that a hazard analysis should not only include the runout area of the landslide but also of its secondary effects such as displacement waves and landslide dams (Oppikofer et al., 2019). This assessment involves a volume analysis of the unstable rock mass, a runout analysis of the rock mass into the valley, an analysis of the thickness of the deposits within the valley, an inundation analysis upriver of the dam, and an analysis of dam stability. The latter is based on empirical data on rockslide dams collected in southern Norway and 


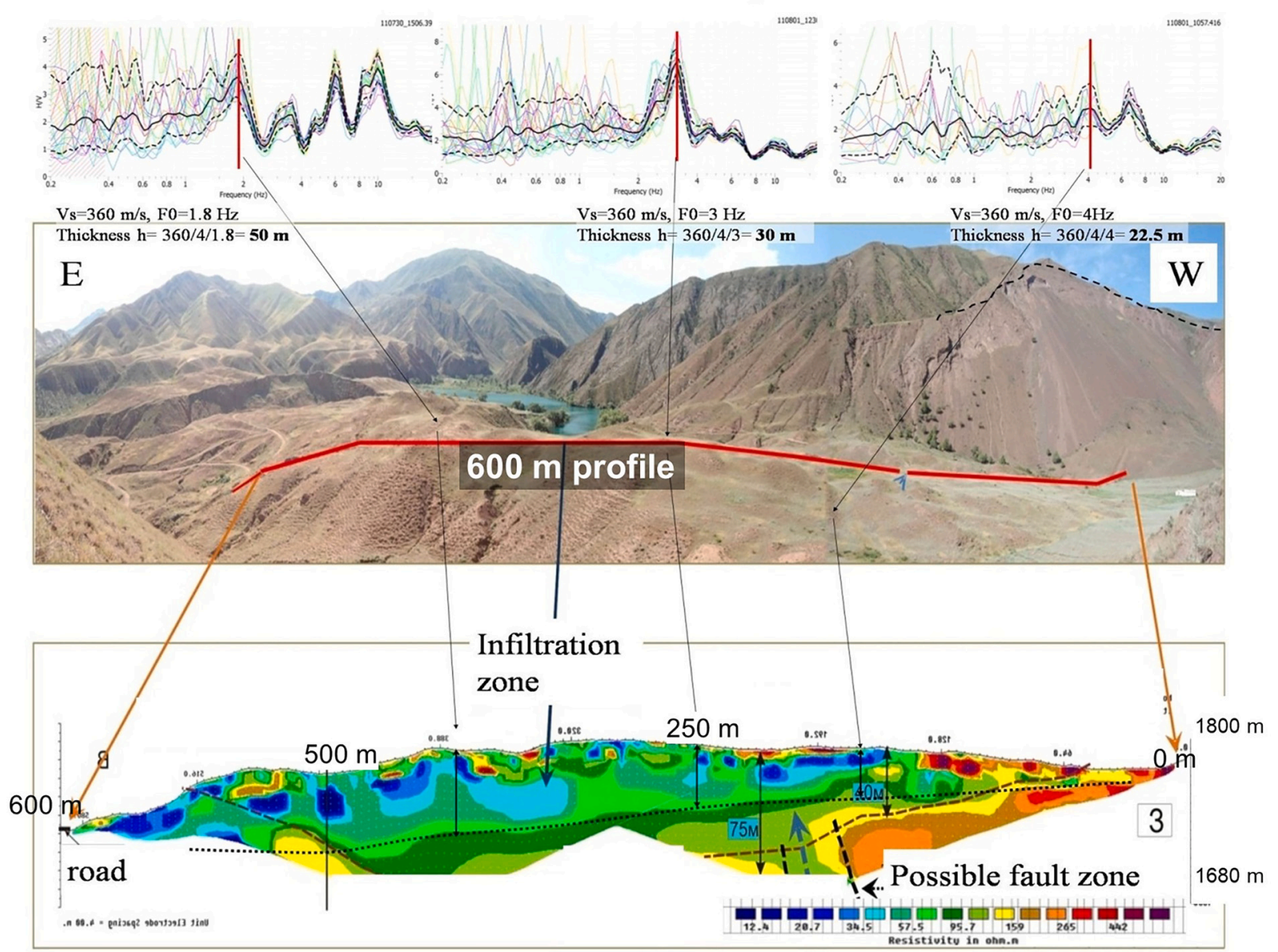

Fig. 9. The results from an integrated H/V and ERT survey at the Ak-kul landslide dam in the Kyrgyz Republic. The zone of lower resistivity, indicating potentially saturated areas, combined with low resonance frequencies and high seismic impedance, indicating zones of weak material, suggests the landslide dam may be at risk of failure in the future. Reproduced with permission from Torgoev et al. (2013).

tested against examples from northern Norway (Jakobsen, 2016) and against the application of the dimensional blockage index proposed by Ermini and Casagli (2003) using the Norwegian data. In contrast to Ermini and Casagli (2003), the Norwegian method does not only distinguish between unstable, uncertain, stable, but also provides a likelihood of instability for the uncertain domain by applying a linear regression through the existing data (Oppikofer et al., 2016b, 2020). Extending this dataset to other geographic settings would make this empirical method more robust. An outburst flood analysis is then included only for those cases where the likelihood of the rockslide is high and the longevity of the dam low (Dahle et al., 2011; Hermanns et al., 2013a).

Landslide dam mitigation comprises two approaches: (1) rapid engineering measures to prevent catastrophic failure, and (2) engineering measures to improve long-term stability. The technique adopted in either of the two approaches could be geotechnical, geological, hydrological, and geophysical, or preferably a combination of two or more of these methods. Indeed, geophysical methods, such as multichannel analysis of surface waves (MASW), microtremor survey, and selfpotential (SP) methods have proven to be important methods that could be used to perform rapid stability assessment in newly formed landslide dams (e.g. Wang et al., 2013). Several geophysical campaigns have monitored seemingly stable, non-remediated landslide dams. Wang et al. (2018a) used combined MTM and SP monitoring methods to identify seepage zones in landslide dams in Japan and the Kyrgyz Republic. Wang et al. (2018b) also conducted SP monitoring on large-scale artificial dams, and identified artificially induced zones of fluid seepage.
Niazi et al. (2010) used ERT to both characterize and monitor the structure of the Hattia Bala landslide dam in Kashmir, identifying low resistivity zones indicating lower-density, high-permeability material prone to seepage. Decreasing resistivity in these zones over time indicated increased seepage through the landslide dam. The fact that newly formed landslide dams are poorly compacted, heterogeneous and highly susceptible to failure justifies the use of a range of engineering geophysical and geotechnical methods to characterise their internal structure and material properties. Interestingly, recent research by Wang et al. (2018b) on selected landslide dams in Japan and Kyrgyzstan observed that zones of low-phase-velocity profiles correspond to the areas that are susceptible to internal erosion, given their low degree of compaction, and thus their high erodibility coefficients. The results obtained from the application of these geophysical and geotechnical investigations would definitely aid in the design and construction of resilient engineering infrastructure against the occurrence of outburst floods from the collapse of landslide dams. Furthermore, the results are also applicable in the development of early warning systems against outburst floods. Feasible mitigative measures against landslide dam failures and outburst floods from dam failures hence require the application of all the preventive actions enumerated by Schuster and Evans (2011) and methods in this paper.

In conclusion, the way forward in landslide dam research, stability assessment, and mitigation lies in the combination of methods and disciplines. This review showed that such multidisciplinary approaches yield the most reliable and most insightful results in landslide dam dating and longevity assessment, improved our knowledge and rapid 
assessment of the dam interior, and hence the development of preferential fluid pathways and the potential zones of weakness, understanding of dam failure processes and timelines, and, finally, advanced the assessment of the entire hazard cascade from slope failure to dambreach flood.

\section{Declaration of Competing Interest}

\section{We declare no conflict of interest}

\section{Acknowledgements}

This research is financially supported by the Funds for Creative Research Groups of China (Grant No. 41521002), the National Science Fund for Outstanding Young Scholars of China (Grant No. 41622206), the Funds for the State Key Laboratory of Geo-hazard Prevention and Geoenvironment Protection Independent Research Project (SKLGP2019Z002), National Key R\&D Program of China (No. 2017YFC1501002). Tomás Pánek acknowledges kind support from Czech Science Foundation project no. 19-16013S. Sincere thanks to the editor, Prof. Chris Fielding, for the kind acceptance of our proposal and encouragement to submit this research work. Many thanks also go to editorial assistant Mr Tim Horscroft for the kind support. Lanxin Dai is thanked for improving Figs. 1 and 3. We thank Dr. Isakbek Torgoev for his contributions to the investigations of the Kol-Tor and Ak-Kul landslide dams.

\section{Reference}

Abdrakhmatov, K., Strom, A., 2006. Dissected rockslide and rock avalanche deposits. In: Shan, Tien (Ed.), Kyrgyzstan, Landslides from Massive Rock Slope Failure. Springer, pp. 551-570.

Abele, G., 1974. Bergsturze in den Alpen. Ihre Verbreitung, Morphologie und Folgeerscheinungen. Wiss. Alpenvereinshefte, 25.

Adams, J., 1981. Earthquake-dammed lakes in New Zealand. Geology 9 (5), 215-219. Adushkin, V.V., 2006. Mobility of rock avalanches triggered by underground nuclear explosions. In: Landslides from Massive Rock Slope Failure. Springer, pp. 267-284.

Adushkin, V.V., 2011. Russian Experience with Blast-fill Dam construction, Natural and Artificial Rockslide Dams. Springer, pp. 595-616.

Alford, D., Schuster, R.L., 2000. Usoi Landslide Dam and Lake Sarez-An Assessment of Hazard and Risk in the Pamir Mountains. United Nations Secretariat for International Strategy for Disaster Reduction, Geneva, Tajikistan.

ASCE/EWRI, 2011. Earthen embankment breaching. J. Hydraul. Eng. 137 (12), 1549-1564.

Assier-Rzadkieaicz, S., Heinrich, P., Sabatier, P.C., Savoye, B., Bourillet, J.F., 2000. Numerical modelling of a landslide-generated tsunami: the 1979 Nice event. Pure Appl. Geophys. 157 (10), 1707-1727.

Avtar, R., Yunus, A.P., Kraines, S., Yamamuro, M., 2015. Evaluation of DEM generation based on Interferometric SAR using TanDEM-X data in Tokyo. Physics Chem. Earth A/B/C 83, 166-177.

Awal, R., 2008. Study on Landslide Dam Failure Due to Sliding and Overtopping.

Awal, R., Nakagawa, H., Baba, Y., Sharma, R.H., Ito, N., 2007. Study on Landslide Dam Failure by Sliding.

Awal, R., Nakagawa, H., Kawaike, K., Baba, Y., Zhang, H., 2008a. Prediction of Flood/ Debris Flow Hydrograph Due to Landslide Dam Failure by Overtopping and Sliding.

Awal, R., Nakagawa, H., Kawaike, K., Baba, Y., Zhang, H., 2008b. An integrated approach to predict outflow hydrograph due to landslide dam failure by overtopping and sliding. Proc. Hydraull. Eng. 52, 151-156.

Awal, R., Nakagawa, H., Kawaike, K., Baba, Y., Zhang, H., 2009. Three Dimensional Transient Seepage and Slope Stability Analysis of Landslide Dam.

Awal, R., Nakagawa, H., Kawaike, K., Baba, Y., Zhang, H., 2011. Experimental study on piping failure of natural dam. J. Jpn Soc. Civil Eng. B1 (Hydraul. Eng.) 67 (4). I_157I_162.

Balescu, S., Ritz, J.-F., Lamothe, M., Auclair, M., Todbileg, M., 2007. Luminescence dating of a gigantic palaeolandslide in the Gobi-Altay mountains, Mongolia. Quat. Geochronol. 2 (1-4), 290-295.

Ballantyne, C.K., Stone, J.O., Fifield, L.K., 1998. Cosmogenic Cl-36 dating of postglacial landsliding at the Storr, Isle of Skye, Scotland. The Holocene 8 (3), 347-351.

Bao, Y., Zhai, S., Chen, J., Xu, P., Sun, X., Zhan, J., Zhang, W., Zhou, X., 2020. The evolution of the Samaoding paleolandslide river blocking event at the upstream reaches of the Jinsha River, Tibetan Plateau. Geomorphology 351, 106970.

Barazzetti, L., Brumana, R., Oreni, D., Previtali, M., Roncoroni, F., 2014. Trueorthophoto generation from UAV images: implementation of a combined photogrammetric and computer vision approach. ISPRS Ann. Photogramm. Remote Sens. Spat. Inform. Sci. 2, 5.
Bardet, J.P., Synolakis, C.E., Davies, H.L., Imamura, F., Okal, E.A., 2003. Landslide Tsunamis: Recent Findings and Research Directions, Landslide Tsunamis: Recent Findings and Research Directions. Springer, pp. 1793-1809.

Beetham, R.D., McSaveney, M.J., Read, S.A.L., 2002. Four extremely large landslides in New Zealand. Landslides 97-102.

Beguería, S., Van Asch, T.W.J., Malet, J.P., Gröndahl, S., 2009. A GIS-based numerical model for simulating the kinematics of mud and debris flows over complex terrain. Nat. Hazards Earth Syst. Sci. 9 (6), 1897-1909.

Belousov, T.P., 1994. On estimation of the recurrence period of Strong earthquakes in the Central Tien Shan. J. Earthquake Predict. Res. 3, 226-236.

Benahmed, N., Bonelli, S., 2012. Investigating concentrated leak erosion behaviour of cohesive soils by performing hole erosion tests. Eur. J. Environ. Civ. Eng. 16 (1), 43-58.

Bendahmane, F., Marot, D., Alexis, A., 2008. Experimental parametric study of suffusion and backward erosion. J. Geotech. Geoenviron. 134 (1), 57-67.

Bianchi-Fasani, G., Esposito, C., Petitta, M., Scarascia-Mugnozza, G., Barbieri, M., Cardarelli, E., Cercato, M., Di Filippo, G., 2011. The Importance of Geological Models in Understanding and Predicting the Life Span of Rockslide Dams: The Case of Scanno Lake, Central Italy, Natural and Artificial Rockslide Dams. Springer, pp. 323-345.

Bout, B., Jetten, V.G., 2018. The validity of flow approximations when simulating catchment-integrated flash floods. J. Hydrol. 556, 674-688.

Bout, B., Lombardo, L., van Westen, C., Jetten, V., 2018a. A new model for integrated multi-hazard modelling of flooding and mass movements in mountainous watersheds, p. 9172.

Bout, B., Lombardo, L., van Westen, C.J., Jetten, V.G., 2018b. Integration of two-phase solid fluid equations in a catchment model for flashfloods, debris flows and shallow slope failures. Environ. Model Softw. 105, 1-16.

Braun, A., Cuomo, S., Petrosino, S., Wang, X., Zhang, L., 2018. Numerical SPH analysis of debris flow run-out and related river damming scenarios for a local case study in SW China. Landslides 15 (3), 535-550.

Brunner, G.W., 1995. HEC-RAS River Analysis System. Hydraulic Reference Manual. Version 1.0, Hydrologic Engineering Center Davis CA.

Brunner, G.W., 2002. Hec-ras (River Analysis System). ASCE, pp. 3782-3787.

Bryan, R.B., Jones, J.A.A., 1997. The significance of soil piping processes: inventory and prospect. Geomorphology 20 (3-4), 209-218. \%U. 10.1016\%2Fs0169-555x\%2897\% 2900024-x.

Burns, B., Barker, R., Ghataora, G.S., 2006. Investigating internal erosion using a miniature resistivity array. NDT \& E Int. 39 (2), 169-174. \%U. 10.1016\%2Fj.ndteint. 2004.12.009.

Cagniard, L., 1953. Basic theory of the magneto- ${ }^{\text {FEL }}$ luric method of geophysical prospecting. Geophysics 18 (3), 605-635. \%U. 10.1190\%2F1.1437915.

Cao, Z., Yue, Z., Pender, G., 2011. Landslide dam failure and flood hydraulics. Part II: coupled mathematical modelling. Nat. Hazards 59 (2), 1021-1045.

Capart, H., 2013. Analytical solutions for gradual dam breaching and downstream river flooding. Water Resour. Res. 49 (4), 1968-1987.

Casagli, N., Cigna, F., Bianchini, S., Hölbling, D., Füreder, P., Righini, G., Del Conte, S., Friedl, B., Schneiderbauer, S., Iasio, C., 2016. Landslide mapping and monitoring by using radar and optical remote sensing: examples from the EC-FP7 project SAFER. Remote Sens. Appl. Soc. Environ. 4, 92-108.

Castellaro, S., Mulargia, F., Bianconi, L., 2005. Passive seismic stratigraphy: a new efficient, fast and economic technique. Geologia tecnica e ambientale 3, 76-102.

Castleton, J.J., Moore, J.R., Aaron, J., Christl, M., Ivy-Ochs, S., 2016. Dynamics and legacy of 4.8 ka rock avalanche that dammed Zion Canyon, Utah, USA. GSA Today 26 (06), 4-9. \%U. 10.1130\%2Fgsatg269a.1.

Cestero, J.A.F., Imran, J., Chaudhry, M.H., 2015. Experimental investigation of the effects of soil properties on levee breach by overtopping. J. Hydraul. Eng. 141 (4) 04014085. \%U. 10.1061\%2F\%28asce\%29hy.1943-7900.0000964.

Chambers, J.E., Kuras, O., Meldrum, P.I., Ogilvy, R.D., Hollands, J., 2006. Electrical resistivity tomography applied to geologic, hydrogeologic, and engineering investigations at a former waste-disposal site. GEOPHYSICS 71 (6), B231-B239. \%U. $10.1190 \% 2 \mathrm{~F} 1.2360184$

Chang, D.S., Zhang, L.M., 2010. Simulation of the erosion process of landslide dams due to overtopping considering variations in soil erodibility along depth. Nat. Hazards Earth Syst. Sci. 10 (4), 933-946.

Chang, D.S., Zhang, L.M., 2013. Critical hydraulic gradients of internal erosion under complex stress states. J. Geotech. Geoenviron. 139 (9), 1454-1467. \%U. 10.1061\% 2F\%28asce\%29gt.1943-5606.0000871.

Chang, D.S., Zhang, L.M., Xu, Y., Huang, R.Q., 2011. Field testing of erodibility of two landslide dams triggered by the 12 May Wenchuan earthquake. Landslides 8 (3), 321-332. \%U. 10.1007\%2Fs10346-011-0256-x.

Charrière, M., Humair, F., Froese, C., Jaboyedoff, M., Pedrazzini, A., Longchamp, C. 2015. From the source area to the deposit: Collapse, fragmentation, and propagation of the Frank Slide. Geol. Soc. Am. Bull. B31243, 1 \%U. 10.1130\%2Fb31243.1.

Chen, H.X., Zhang, L.M., 2015. EDDA 1.0: integrated simulation of debris flow erosion, deposition and property changes. Geosci. Model Dev. 8 (3).

Chen, C.-Y., Chen, T.-C., Yu, F.-C., Hung, F.-Y., 2004. A landslide dam breach induced debris flow-a case study on downstream hazard areas delineation. Environ. Geol. 47 (1), 91-101.

Chen, S.-C., Lin, T.-W., Chen, C.-Y., 2015a. Modeling of natural dam failure modes and downstream riverbed morphological changes with different dam materials in a flume test. Eng. Geol. 188, 148-158. \%U. 10.1016\%2Fj.enggeo.2015.01.016.

Chen, Z., Ma, L., Yu, S., Chen, S., Zhou, X., Sun, P., Li, X., 2015b. Back analysis of the draining process of the Tangjiashan barrier lake. J. Hydraul. Eng. 141 (4), 05014011. 
Chen, J., Zhou, W., Cui, Z., Li, W., Wu, S., Ma, J., 2018. Formation process of a large paleolandslide-dammed lake at Xuelongnang in the upper Jinsha River, SE Tibetan Plateau: constraints from OSL and 14C dating. Landslides 15 (12), 2399-2412. \%U. 10.1007\%2Fs10346-018-1056-3.

Chigira, M., 2009. September 2005 rain-induced catastrophic rockslides on slopes affected by deep-seated gravitational deformations, Kyushu, southern Japan. Eng. Geol. 108 (1-2), 1-15.

Chinnarasri, C., Jirakitlerd, S., Wongwises, S., 2004. Embankment dam breach and its outflow characteristics. Civ. Eng. Environ. Syst. 21 (4), 247-264. \%U. 10.1080\%2F1 0286600412331328622 .

Clerici, A., Perego, S., 2000. Simulation of the Parma River blockage by the Corniglio landslide (Northern Italy). Geomorphology 33 (1-2), 1-23.

Colangelo, G., Lapenna, V., Perrone, A., Piscitelli, S., Telesca, L., 2006. 2D self-potential tomographies for studying groundwater flows in the Varco d'Izzo landslide (Basilicata, southern Italy). Eng. Geol. 88 (3-4), 274-286.

Coleman, S.E., Andrews, D.P., Webby, M.G., 2002. Overtopping breaching of noncohesive homogeneous embankments. J. Hydraul. Eng. 128 (9), 829-838.

Colesanti, C., De Zan, F., Ferretti, A., Prati, C., Rocca, F., 2003. Generation of DEM with sub-metric vertical accuracy from 30'ERS-ENVISAT pairs, Proc. of FRINGE 2003 Workshop, Frascati, Italy, pp. 1-5.

Corsini, A., Cervi, F., Daehne, A., Ronchetti, F., Borgatti, L., 2009. Coupling geomorphic field observation and LIDAR derivatives to map complex landslides, Landslides processes - from geomorphologic mapping to dynamic modeling, proceedings of the landslide processes conference, pp. 6-7.

Costa, J.E., Schuster, R.L., 1988. The formation and failure of natural dams. Geol. Soc. Am. Bull. 100 (7), 1054-1068.

Crist, E.P., 1985. A TM Tasseled Cap equivalent transformation for reflectance factor data. Remote Sens. Environ. 17 (3), 301-306. \%U. 10.1016\%2F0034-4257\%2885\% 2990102-6.

Cristo, C.D., Evangelista, S., Greco, M., Iervolino, M., Leopardi, A., Vacca, A., 2017. Dambreak waves over an erodible embankment: experiments and simulations. J. Hydraul. Res. 56 (2), 196-210. \%U. 10.1080\%2F00221686.2017.1313322.

Crosetto, M., Crippa, B., Biescas, E., 2005. Early detection and in-depth analysis of deformation phenomena by radar interferometry. Eng. Geol. 79 (1-2), 81-91. \%U. 10.1016\%2Fj.enggeo.2004.10.016.

Crosta, G.B., Imposimato, S., Roddeman, D.G., 2003. Numerical modelling of large landslides stability and runout. Nat. Hazards Earth Syst. Sci. 3 (6), 523-538.

Crosta, G.B., Frattini, P., Fusi, N., Sosio, R., 2006. Formation, characterization and modelling of the 1987 Val Pola rock-avalanche dam (Italy). Ital. J. Eng. Geol. Envir. (Special Issue I), 145-150.

Crosta, G.B., Frattini, P., Fusi, N., 2007. Fragmentation in the Val Pola rock avalanche, Italian Alps. J. Geophys. Res. Earth Surf. 112 (F1).

Crosta, G.B., Imposimato, S., Roddeman, D., 2009. Numerical modelling of entrainment/ deposition in rock and debris-avalanches. Eng. Geol. 109 (1), 135-145.

Crosta, G.B., Frattini, P., Fusi, N., Sosio, R., 2010. Formation, Characterisation and Modeling of the Val Pola Rock-Avalanche Dam (Italy), Natural and Artificial Rockslide Dams. Springer Berlin Heidelberg, pp. 347-368. \%U. 10.1007\%2F9 78-3-642-04764-0_12.

Cruden, D.M., Varnes, D.J., 1996. Landslides: investigation and mitigation. Chapter 3Landslide types and processes. Transportation research board special report(247).

Cui, P., Zhu, X., 2011. Surge generation in reservoirs by landslides triggered by the wenchuan earthquake. J. Earthquake Tsunami 05 (05), 461-474.

Cui, P., Zhou, G.G.D., Zhu, X.H., Zhang, J.Q., 2013. Scale amplification of natural debris flows caused by cascading landslide dam failures. Geomorphology 182, 173-189.

Cundall, P.A., Strack, O.D.L., 1979. A discrete numerical model for granular assemblies. Geotechnique 29 (1), 47-65.

Dahle, H., Bjerke, P.L., Crosta, G., Hermanns, R.L., Anda, E., Saintot, A., 2011. Faresoner for utløp, oppdemming og flom som følge av fjellskredfare ved Mannen. NGU report.

Dai, F.C., Lee, C.F., Deng, J.H., Tham, L.G., 2005. The 1786 earthquake-triggered landslide dam and subsequent dam-break flood on the Dadu River, southwestern China. Geomorphology 65 (3-4), 205-221.

Das, A., Jayashree, C., Viswanadham, B.V.S., 2009. Effect of randomly distributed geofibers on the piping behaviour of embankments constructed with fly ash as a fill material. Geotext. Geomembr. 27 (5), 341-349. \%U. 10.1016\%2Fj.geotexmem.200 9.02.004.

Davies, T., McSaveney, M., 2006. Mobility of long-runout rock avalanches. In: Clague, J. J., Stead, D. (Eds.), Landslides. Cambridge University Press, pp. 50-58. \%U. 10.1017 \%2Fcbo9780511740367.006.

Davies, T.R., McSaveney, M.J., 2011. Rock-avalanche size and runout-implications for landslide dams. In: Natural and Artificial Rockslide Dams. Springer, pp. 441-462.

Davies, T.R., Manville, V., Kunz, M., Donadini, L., 2007. Modeling landslide dambreak flood magnitudes: case study. J. Hydraul. Eng. 133 (7), 713-720.

Davis, J.L., Annan, A.P., 1989. Ground-penetrating radar for high-resolution mapping of soil and rock stratigraphy 1. Geophys. Prospect. 37 (5), 531-551.

Davison, M., Hassan, M., Gimeno, O., Van Damme, M., Goff, C., 2013. A benchmark study on dam breach and consequence estimation using EMBREA and life safety model. In: ICOLD Theme C: Computational challenges in Consequence Estimation for Risk Management. HR Wallingford, Wallingford, UK, pp. 241-254.

De Roo, A.P.J., Wesseling, C.G., Van Deursen, W.P.A., 2000. Physically based river basin modelling within a GIS: the LISFLOOD model. Hydrol. Process. 14 (11-12), 1981-1992.

Delaney, K.B., Evans, S.G., 2011. Rockslide Dams in the Northwest Himalayas (Pakistan, India) and the Adjacent Pamir Mountains (Afghanistan, Tajikistan), Central Asia Natural and Artificial Rockslide Dams. Springer, pp. 205-242.
Delaney, K.B., Evans, S.G., 2015. The 2000 Yigong landslide (Tibetan Plateau), rockslidedammed lake and outburst flood: review, remote sensing analysis, and process modelling. Geomorphology 246, 377-393.

Delaney, K.B., Evans, S.G., 2017. The evolution (2010-2015) and engineering mitigation of a rockslide-dammed lake (Hunza River, Pakistan)\$ $\backslash$ mathsemicolon\$ characterisation by analytical remote sensing. Eng. Geol. 220, 65-75. \%U. 10.1016\% 2Fj.enggeo.2017.01.003.

Delgado, F., Zerathe, S., Audin, L., Schwartz, S., Benavente, C., Carcaillet, J., Bourlès, D. L., Team, A., 2020. Giant landslide triggerings and paleoprecipitations in the Central Western Andes: The aricota rockslide dam (South Peru). Geomorphology 350, 106932. \%U. 10.1016\%2Fj.geomorph.2019.106932.

Delunel, R., Hantz, D., Braucher, R., Bourlès, D.L., Schoeneich, P., Deparis, J., 2010. Surface exposure dating and geophysical prospecting of the Holocene Lauvitel rock slide (French Alps). Landslides 7 (4), 393-400. \%U. 10.1007\%2Fs10346-010-0221 -0 .

Deng, Z., Wu, S., Fan, Z., Yan, Z., Wu, J., 2019. Research on the Overtopping-Induced Breaching Mechanism of Tailings Dam and Its Numerical Simulation. Adv. Civ. Eng. 2019, 1-10. \%U. 10.1155\%2F2019\%2F3264342.

Dong, J.-J., Li, Y.-S., Kuo, C.-Y., Sung, R.-T., Li, M.-H., Lee, C.-T., Chen, C.-C., Lee, W.-R., 2011a. The formation and breach of a short-lived landslide dam at Hsiaolin village, Taiwan-part I: post-event reconstruction of dam geometry. Eng. Geol. 123 (1-2), 40-59.

Dong, J.-J., Li, Y.-S., Kuo, C.-Y., Sung, R.-T., Li, M.-H., Lee, C.-T., Chen, C.-C., Lee, W.-R., 2011b. The formation and breach of a short-lived landslide dam at Hsiaolin village, Taiwan - part I: Post-event reconstruction of dam geometry. Eng. Geol. 123 (1-2), 40-59. \%U. 10.1016\%2Fj.enggeo.2011.04.001.

Dong, G., Zhang, F., Ma, M., Fan, Y., Zhang, J., Wang, Z., Chen, F., 2014. Ancient landslide-dam events in the Jishi Gorge, upper Yellow River valley, China. Quater. Res. 81 (3), 445-451. \%U. 10.1016\%2Fj.yqres.2013.09.003.

Donohue, S., Gavin, K., Long, M., Tolooiyan, A., Trafford, A., 2011. Understanding Irish Landslides Using Geophysics. Geophysical Association of Ireland Seminar on Engineering Geophysics.

Dufresne, A., Bösmeier, A., Prager, C., 2016. Sedimentology of rock avalanche deposits Case study and review. Earth Sci. Rev. 163, 234-259. \%U. 10.1016\%2Fj.earscir ev.2016.10.002.

Dufresne, A., Ostermann, M., Preusser, F., 2018. River-damming, late-Quaternary rockslides in the Ötz Valley region (Tyrol, Austria). Geomorphology 310, 153-167.

Dufresne, A., Wolken, G., Hibert, C., Bessette-Kirton, E., Coe, J.A., Geertsema, M., Ekström, G., 2019. The 2016 Lamplugh rock avalanche, Alaska: deposit structures and emplacement dynamics. Landslides 16 (12), 2301-2319.

Dunne, T., 1990. Chapter 1. Hydrology mechanics, and geomorphic implications of erosion by subsurface flow, Groundwater Geomorphology $\$ \backslash$ mathsemicolon $\$$ The Role of Subsurface Water in Earth-Surface Processes and Landforms. Geological Society of America, pp. 1-28. \%U. 10.1130\%2Fspe252-p1.

Dunning, S.A., 2006. The grain size distribution of rock-avalanche deposits in valleyconfined settings. Ital. J. Eng. Geol. Environ. 1, 117-121.

Dunning, S.A., Armitage, P.J., 2011. The Grain-Size Distribution of Rock-Avalanche Deposits: Implications for Natural Dam Stability, Natural and Artificial Rockslide Dams. Springer, pp. 479-498.

Dunning, S.A., Petley, D.N., Rosser, N.J., Strom, A.L., 2005. The morphology and sedimentology of valley confined rock-avalanche deposits and their effect on potential dam hazard, pp. 691-701.

Dunning, S.A., Rosser, N.J., Petley, D.N., Massey, C.R., 2006. Formation and failure of the Tsatichhu landslide dam, Bhutan. Landslides 3 (2), 107-113.

Dupont, E., Dewals, B., Archambeau, P., Erpicum, S., Pirotton, M., 2007. Experimental and numerical study of the breaching of an embankment dam, Proceedings of the 32nd IAHR Biennial Congress-Harmonizing the demands from art and nature. Di Silvio, Giampolo.

Eeckhaut, M.V.D., Poesen, J., Verstraeten, G., Vanacker, V., Nyssen, J., Moeyersons, J. Beek, L.P.H.v., Vandekerckhove, L., 2007. Use of LIDAR-derived images for mapping old landslides under forest. Earth Surf. Process. Landf. 32 (5), 754-769.

Emmer, A., Klimeš, J., Mergili, M., Vilímek, V., Cochachin, A., 2016. 882 lakes of the Cordillera Blanca: An inventory, classification, evolution and assessment of susceptibility to outburst floods. CATENA 147, 269-279. \%U. 10.1016\%2Fj catena.2016.07.032.

Ermini, L., Casagli, N., 2002. Criteria for a preliminary assessment of landslide dam evolution. In: Landslides_-Proceedings of 1st European Conference on Landslides; Rybar, J., Stemberk, J., Wagner, P., Eds, pp. 157-162.

Ermini, L., Casagli, N., 2003. Prediction of the behaviour of landslide dams using a geomorphological dimensionless index. Earth Surf. Process. Landforms: J. Br. Geomorphol. Res. Group 28 (1), 31-47.

Ermini, L., Casagli, N., Farina, P., 2006. Landslide dams: analysis of case histories and new perspectives from the application of remote sensing monitoring techniques to hazard and risk assessment. Ital. J. Eng. Geol. Environ. Special 1, 45-52.

Evans, S.G., 1986. The maximum discharge of outburst floods caused by the breaching of man-made and natural dams. Can. Geotech. J. 23 (3), 385-387.

Fan, X., Gorum, T., van Westen, C.J., Xu, Q., Tang, C., Huang, R., 2009. Distribution of large landslides and landslide dams triggered by the Wenchuan earthquake. Sichuan, China, p. 2863.

Fan, X., Tang, C.X., Van Westen, C.J., Alkema, D., 2012a. Simulating dam-breach flood scenarios of the Tangjiashan landslide dam induced by the Wenchuan Earthquake. Nat. Hazards Earth Syst. Sci. 12 (10), 3031.

Fan, X., van Westen, C.J., Xu, Q., Gorum, T., Dai, F., 2012b. Analysis of landslide dams induced by the 2008 Wenchuan earthquake. J. Asian Earth Sci. 57, 25-37.

Fan, X., van Westen, C.J., Xu, Q., Gorum, T., Dai, F., Wang, G., Huang, R., 2013. Spatial distribution of landslide dams triggered by the 2008 Wenchuan Earthquake 
(Editors). In: Margottini, C., Canuti, P., Sassa, K. (Eds.), Landslide Science and Practice. Springer Berlin Heidelberg, Berlin, Heidelberg, pp. 279-285. \%@ 978-3642-31426-1 978-3-642-31427-8

Fan, X., van Westen, C.J., Tang, C., Xu, Q., Huang, R., Wang, G., 2015. The classification of damming landslides and landslide dams induced by the Wenchuan Earthquake. In: Lollino, G., Giordan, D., Crosta, G.B., Corominas, J., Azzam, R., Wasowski, J., Sciarra, N. (Eds.), Engineering Geology for Society and Territory - Volume 2. Springer International Publishing, Cham, pp. 1143-1147.

Fan, X., Scaringi, G., Korup, O., West, A.J., van Westen, C.J., Tanyas, H., Hovius, N., Hales, T.C., Jibson, R.W., Allstadt, K.E., Zhang, L., Evans, S.G., Xu, C., Li, G., Pei, X., Xu, Q., Huang, R., 2019a. Earthquake-Induced Chains of Geologic Hazards: Patterns, Mechanisms, and Impacts. Rev. Geophys. 57 (2), 421-503.

Fan, X., Xu, Q., Alonso-Rodriguez, A., Siva Subramanian, S., Li, W., Zheng, G., Dong, X., Huang, R., 2019b. Successive landsliding and damming of the Jinsha River in eastern Tibet, China: prime investigation, early warning, and emergency response. Landslides 16 (5), 1003-1020.

Fan, X., Yang, F., Siva Subramanian, S., Xu, Q., Feng, Z., Mavrouli, O., Peng, M. Ouyang, C., Jansen, J.D., Huang, R., 2019c. Prediction of a multi-hazard chain by an integrated numerical simulation approach: the Baige landslide, Jinsha River, China. Landslides 17, 147-164.

Fan, X., Dufresne, A., Subramanian, S.S., Strom, A., Hermanns, R., Stefanelli, C.T., Hewitt, K., Yunus, A.P., Dunning, S., Capra, L., Geertsema, M., Miller, B., Casagli, N., Jansen, J.D., Xu, Q., 2020. The formation and impact of landslide dams - State of the art. Earth Sci. Rev. 103116.

Farr, T.G., Rosen, P.A., Caro, E., Crippen, R., Duren, R., Hensley, S., Kobrick, M., Paller, M., Rodriguez, E., Roth, L., others, 2007. The shuttle radar topography mission. Rev. Geophys. 45 (2).

Fell, R., Fry, J.-J., 2013. State of The Art on the Likelihood of Internal Erosion of Dams and Levees by Means of Testing, Erosion in Geomechanics Applied to Dams and Levees. John Wiley \& Sons, Inc., pp. 1-99. \%U. 10.1002\%2F9781118577165.ch1

Ferretti, A., Prati, C., Rocca, F., 2001. Permanent scatterers in SAR interferometry. IEEE Trans. Geosci. Remote Sens. 39 (1), 8-20.

Feyisa, G.L., Meilby, H., Fensholt, R., Proud, S.R., 2014. Automated Water Extraction Index: A new technique for surface water mapping using Landsat imagery. Remote Sens. Environ. 140, 23-35. \%U doi:10.1016\%2Fj.rse.2013.08.029.

Field, E., Jacob, K., 1993. The theoretical response of sedimentary layers to ambient seismic noise. Geophys. Res. Lett. 20 (24), 2925-2928.

Fisher, A., Flood, N., Danaher, T., 2016. Comparing Landsat water index methods for automated water classification in eastern Australia. Remote Sens. Environ. 175, 167-182. \%U doi:10.1016\%2Fj.rse.2015.12.055.

Fleshman, M.S., Rice, J.D., 2014. Laboratory modeling of the mechanisms of piping erosion initiation. J. Geotech. Geoenviron. 140 (6), 04014017. \%U doi:10.1061\%2F \%28asce\%29gt.1943-5606.0001106.

Foster, M., Fell, R., Spannagle, M., 2000. The statistics of embankment dam failures and accidents. Can. Geotech. J. 37 (5), 1000-1024. \%U doi:10.1139\%2Ft00-030.

Fox, G.A., Felice, R.G., Midgley, T.L., Wilson, G.V., Al-Madhhachi, A.-S.T., 2013 Laboratory soil piping and internal erosion experiments: evaluation of a soil piping model for low-compacted soils. Earth Surf. Process. Landf. 39 (9), 1137-1145. \%U doi:10.1002\%2Fesp.3508.

Fread, D.L., 1984. DAMBRK: The NWS dam-break flood forecasting model, 4. Hydrologic Research Laboratory, National Weather Service, NOAA Silver Spring.

Fread, D.L., 1988. BREACH, an erosion model for earthen dam failures. Hydrologic Research Laboratory, National Weather Service, NOAA.

Fread, D.L., 1996. Dam-Breach Floods, Hydrology of Disasters. Springer, pp. 85-126.

Fread, D.L., 2014. National Weather Service models to forecast dam-breach floods. Hydrol. Disast. 192-211.

Garambois, S., Sénéchal, P., Perroud, H., 2002. On the use of combined geophysical methods to assess water content and water conductivity of near-surface formations. J. Hydrol. 259 (1-4), 32-48.

García-García, F., Sánchez-Gómez, M., Navarro, V., Pla, S., 2011. Formation, infill, and dissection of a latest-Pleistocene landslide-dammed reservoir (Betic Cordillera, Southern Spain): Upstream and downstream geomorphological and sedimentological evidence. Quat. Int. 233 (1), 61-71. \%U. 10.1016\%2Fj.quaint.2010.07.010.

Geertsema, M., Clague, J.J., 2006. 1,000-year record of landslide dams at Halden Creek, northeastern British Columbia. Landslides 3 (3), 217-227.

Glancy, P.A., Bell, J.W., 2000. Landslide-induced flooding at Ophir Creek, Washoe County, western Nevada, May 30, 1983. 2330-7102, US Geological Survey.

Glicken, H.X., Meyer, W., Sabol, M.A., 1989. Geology and ground-water hydrology of Spirit Lake blockage, Mount St. Helens, Wahington, with implications for lake retention, 1789 .

Görüm, T., 2019. Landslide recognition and mapping in a mixed forest environment from airborne LiDAR data. Eng. Geol. 258, 105155. \%U. 10.1016\%2Fj.enggeo.2019.1051 55.

Grandjean, G., Gourry, J.C., Sanchez, O., Bitri, A., Garambois, S., 2011. Structural study of the Ballandaz landslide (French Alps) using geophysical imagery. J. Appl. Geophys. 75 (3), 531-542. \%U. 10.1016\%2Fj.jappgeo.2011.07.008.

Gregoretti, C., Maltauro, A., Lanzoni, S., 2010. Laboratory Experiments on the Failure of Coarse Homogeneous Sediment Natural Dams on a Sloping Bed. J. Hydraul. Eng. 136 (11), 868-879. \%U. 10.1061\%2F\%28asce\%29hy.1943-7900.0000259.

Griffiths, D.H., Barker, R.D., 1993. Two-dimensional resistivity imaging and modelling in areas of complex geology. J. Appl. Geophys. 29 (3-4), 211-226.

Groeber, P., 1916. Informe sobre las causas que han producido las crecientes del río Colorado (Territorios del Neuquén y La Pampa) en 1914. 1-29 p. Buenos Aires: Dirección General de Minas, Geología e Hidrogeología.

Guerrero, J., Gutiérrez, F., García-Ruiz, J.M., Carbonel, D., Lucha, P., Arnold, L.J., 2018 Landslide-dam paleolakes in the Central Pyrenees, Upper Gállego River Valley, NE
Spain: timing and relationship with deglaciation. Landslides 15 (10), 1975-1989. \% U. 10.1007\%2Fs10346-018-1018-9.

Guzzetti, F., Mondini, A.C., Cardinali, M., Fiorucci, F., Santangelo, M., Chang, K.-T., 2012. Landslide inventory maps: New tools for an old problem. Earth Sci. Rev. 112 (1-2), 42-66.

Hamilton, W.L., 2014. Ancient lakes of Zion National Park. Geol. Utah's Far South: Utah Geol. Assoc. Publ. 43, 1-23.

Hancox, G.T., McSaveney, M.J., Manville, V.R., Davies, T.R., 2005. The October 1999 Mt Adams rock avalanche and subsequent landslide dam-break flood and effects in Poerua River, Westland, New Zealand. N. Z. J. Geol. Geophys. 48 (4), 683-705.

Hanisch, J., Söder, C.O., 2000. Geotechnical assessment of the Usoi landslide dam and the right bank of Lake Sarez. Usoi Landslide dam and lake Sarez. An assessment of hazard and risk in the Pamir mountains, Tajikistan. ISDR Prev. Ser. 1, 23-42.

Hanisch, J., Rybár̆, J., Stemberk, J., 2002. Usoi landslide dam in Tajikistan-the world's highest dam, First stability assessment of the rock slopes at Lake Sarez, The 1st European Conference on Landslides, pp. 189-197.

Han-Qiu, X., 2005. A study on information extraction of water body with the modified normalized difference water index (MNDWI). J. Remote Sens. 5, 589-595.

Hanson, G.J., Cook, K.R., Hunt, S.L., 2005. Physical modeling of overtopping erosion and breach formation of cohesive embankments. Trans ASAE 48 (5), 1783-1794. \%U. 10.13031\%2F2013.20012.

Hanson, G.J., Tejral, R.D., Hunt, S.L., Temple, D.M., 2010. Internal erosion and impact of erosion resistance, Proceedings of the 30th US Society on dams annual meeting and conference, pp. 773-784.

Hartvich, F., 2008. A reconstruction of a former rockslide-dammed lake: the case of the Kokomeren River valley (Tien Shan, Kyrgyzstan). Poster presentation at the EGU conference, Vien, 2008.

Havenith, H.-B., Torgoev, I., Torgoev, A., Strom, A., Xu, Y., Fernandez-Steeger, T., 2015. The Kambarata 2 blast-fill dam, Kyrgyz Republic:blast event, geophysical monitoring and dam structure modelling. Geoenviron. Disast. 2 (1), 11.

Havenith, H.-B., Torgoev, I., Ischuk, A., 2018. Integrated Geophysical-Geological 3D Model of the Right-Bank Slope Downstream from the Rogun Dam Construction Site, Tajikistan. Int. J. Geophys. 2018, 1-16. \%U. 10.1155\%2F2018\%2F1641789.

Heim, A., 1932. Landslides and Human Lives (Bergsturz und Menschenleben), 196. BiTech Publishers, Vancouver, BC.

Hermanns, R.L., Niedermann, S., 2011. Late Pleistocene-early Holocene paleoseismicity deduced from lake sediment deformation and coeval landsliding in the Calchaquíes valleys, NW Argentina, Geological Criteria for Evaluating Seismicity Revisited: Forty Years of Paleoseismic Investigations and the Natural Record of Past Earthquakes. Geological Society of America. \%U. 10.1130\%2F2011.2479\%2808\%29.

Hermanns, R.L., Schellenberger, A., 2008. Quaternary tephrochronology helps define conditioning factors and triggering mechanisms of rock avalanches in NW Argentina. Quat. Int. 178 (1), 261-275.

Hermanns, R.L., Niedermann, S., Garcia, A.V., Gomez, J.S., Strecker, M.R., 2001. Neotectonics and catastrophic failure of mountain fronts in the southern intraAndean Puna Plateau, Argentina. Geology 29 (7), 619-622.

Hermanns, R.L., Niedermann, S., Ivy-Ochs, S., Kubik, P.W., 2004. Rock avalanching into a landslide-dammed lake causing multiple dam failure in Las Conchas valley (NW Argentina) - evidence from surface exposure dating and stratigraphic analyses. Landslides 1 (2), 113-122.

Hermanns, R.L., Blikra, L.H., Longva, O., 2009. Relation between rockslide dam and valley morphology and its impact on rockslide dam longevity and control on potential breach development based on examples from Norway and the Andes. na.

Hermanns, R.L., Folguera, A., Penna, I., Fauqué, L., Niedermann, S., 2011a. Landslide dams in the Central Andes of Argentina (northern Patagonia and the Argentine northwest), Natural and artificial rockslide dams. Springer, pp. 147-176.

Hermanns, R.L., Hewitt, K., Strom, A., Evans, S.G., Dunning, S.A., ScarasciaMugnozza, G., 2011b. The classification of rockslide dams, Natural and artificial rockslide dams. Springer, pp. 581-593.

Hermanns, R.L., Hansen, L., Sletten, K., Böhme, M., Bunkholt, H., Dehls, J.F., Eilertsen, R., Fischer, L., Lheureux, J.S., Høgaas, F., 2012. Systematic Geological Mapping for Landslide Understanding in the Norwegian context. Landslide and Engineered Slopes: Protecting Society Through Improved Understanding. Taylor \& Francis Group, London, pp. 265-271.

Hermanns, R.L., Dahle, H., Bjerke, P.L., Crosta, G.B., Anda, E., Blikra, L.H., Saintot, A., Longva, O., 2013a. Rockslide dams in møre og romsdal county, Norway, Landslide science and practice. Springer, pp. 3-12.

Hermanns, R.L., L'Heureux, J.-S., Blikra, L.H., 2013b. Landslide triggered tsunami, displacement wave. Encyclopedia of Natural Hazards 611-615.

Hermanns, R.L., Fauqué, L., Wilson, C.G.J., 2015. 36Cl terrestrial cosmogenic nuclide dating suggests Late Pleistocene to Early Holocene mass movements on the south face of Aconcagua mountain and in the Las Cuevas-Horcones valleys, Central Andes, Argentina. Geol. Soc. Lond., Spec. Publ. 399 (1), 345-368.

Hermanns, R.L., Schleier, M., Böhme, M., Blikra, L.H., Gosse, J., Ivy-Ochs, S., Hilger, P., 2017. Rock-avalanche activity in W and S Norway peaks after the retreat of the Scandinavian Ice Sheet, Workshop on World Landslide Forum. Springer, pp. 331-338.

Hewitt, K., 1982. Natural dams and outburst floods of the Karakoram Himalaya. IAHS 138, 259-269.

Hewitt, K., Clague, J.J., Orwin, J.F., 2008. Legacies of catastrophic rock slope failures in mountain landscapes. Earth Sci. Rev. 87 (1-2), 1-38.

Hewitt, K., Gosse, J., Clague, J.J., 2011. Rock avalanches and the pace of late Quaternary development of river valleys in the Karakoram Himalaya. Geol. Soc. Am. Bull. 123 (9-10), 1836-1850. \%U. 10.1130\%2Fb30341.1.

Hilger, P., Hermanns, R.L., Gosse, J.C., Jacobs, B., Etzelmüller, B., Krautblatter, M., 2018. Multiple rock-slope failures from Mannen in Romsdal Valley, western Norway, 
revealed from Quaternary geological mapping and 10Be exposure dating. The Holocene 28 (12), 1841-1854.

Hilger, P., Gosse, J.C., Hermanns, R.L., 2019. How significant is inheritance when dating rockslide boulders with terrestrial cosmogenic nuclide dating?- - case study of an historic event. Landslides 16 (4), 729-738. \%U. 10.1007\%2Fs10346-018-01132-0.

Hungr, O., 1995. A model for the runout analysis of rapid flow slides, debris flows, and avalanches. Can. Geotech. J. 32 (4), 610-623.

Hungr, O., 2011. Prospects for prediction of landslide dam geometry using empirical and dynamic models, Natural and Artificial Rockslide Dams. Springer, pp. 463-477.

Hungr, O., Leroueil, S., Picarelli, L., 2014. The Varnes classification of landslide types, an update. Landslides 11 (2), 167-194.

Hunt, S.L., Hanson, G.J., Cook, K.R., Kadavy, K.C., 2005. Breach widening observations from earthen embankment tests. Trans ASAE 48 (3), 1115-1120. \%U. 10.13031\% 2F2013.18521.

Intrieri, E., Raspini, F., Fumagalli, A., Lu, P., Del Conte, S., Farina, P., Allievi, J., Ferretti, A., Casagli, N., 2018. The Maoxian landslide as seen from space: detecting precursors of failure with Sentinel-1 data. Landslides 15 (1), 123-133.

Ischuk, A.R., 2011. Usoi rockslide dam and lake Sarez, Pamir mountains, Tajikistan, Natural and Artificial Rockslide Dams. Springer, pp. 423-440.

Ivy-Ochs, S., Poschinger, A.V., Synal, H.A., Maisch, M., 2009. Surface exposure dating of the Flims landslide, Graubünden, Switzerland. Geomorphology 103 (1), 104-112.

Ivy-Ochs, S., Martin, S., Campedel, P., Hippe, K., Alfimov, V., Vockenhuber, C., Andreotti, E., Carugati, G., Pasqual, D., Rigo, M., Viganò, A., 2017. Geomorphology and age of the Marocche di Dro rock avalanches (Trentino, Italy). Quat. Sci. Rev. 169, 188-205. \%U. 10.1016\%2Fj.quascirev.2017.05.014.

Jaboyedoff, M., Oppikofer, T., Abellán, A., Derron, M.-H., Loye, A., Metzger, R., Pedrazzini, A., 2012. Use of LIDAR in landslide investigations: a review. Nat. Hazards 61 (1), 5-28.

Jakobsen, V.U., 2016. An empirical approach for determining the evolution and behavior of rockslide dams.-Development of a empirical tool based on geomorphic parameters of rockslide dams and impounded valleys to predict future rockslide dam heights and their relative longevity.

Jin-chi, H., 2008. Numerical modeling of flow through breach of landslide dams. SHUILI XUEBAO 39 (10).

Jing, X., Chen, Y., Williams, D., Serna, M., Zheng, H., 2019. Overtopping failure of a reinforced tailings dam: laboratory investigation and forecasting model of dam failure. Water 11 (2), 315-\%U, 10.3390\%2Fw11020315.

Johnson, H.P., 1978. Paleomagnetism of Igneous rock samples -DSDP LEG 45.

Jongmans, D., Garambois, S., 2007. Geophysical investigation of landslides: a review. Bulletin de la Société géologique de France 178 (2), 101-112.

Kakinuma, T., Shimizu, Y., 2014. Large-scale experiment and numerical modeling of a Riverine Levee Breach. J. Hydraul. Eng. 140 (9), 04014039. \%U. 10.1061\%2F\% 28asce\%29hy.1943-7900.0000902.

Ke, L., Takahashi, A., 2012a. Influence of internal erosion on deformation and strength of gap-graded non-cohesive soil. Proceedings of the Sixth International Conference on Scour and Erosion, Paris, pp. 847-854.

Ke, L., Takahashi, A., 2012b. Strength reduction of cohesionless soil due to internal erosion induced by one-dimensional upward seepage flow. Soils Found. 52 (4), 698-711.

Kojan, E., Hutchinson, J.N.D., 1978. Mayunmarca rockslide and debris flow, Peru, Developments in Geotechnical Engineering. Elsevier, pp. 315-353.

Kokusho, T., Fujikura, Y., 2008. Effect of particle gradation on seepage failure in granular soils. In: Proceedings 4th International Conference on Scour and Erosion (ICSE-4). November 5-7, 2008, Tokyo, Japan, pp. 497-504.

Korchevskiy, V.F., Kolichko, A.V., Strom, A.L., Pernik, L.M., Abdrakhmatov, K.E., 2011 Utilisation of data derived from large-scale experiments and study of natural blockages for blast-fill dam design, Natural and Artificial Rockslide Dams. Springer, pp. 617-637.

Korup, O., 2002. Recent research on landslide dams-a literature review with special attention to New Zealand. Prog. Phys. Geogr. 26 (2), 206-235.

Korup, O., 2005. Geomorphic imprint of landslides on alpine river systems, southwest New Zealand. Earth Surf. Process. Landf. 30 (7), 783-800.

Lang, A., Moya, J., Corominas, J., Schrott, L., Dikau, R., 1999. Classic and new dating methods for assessing the temporal occurrence of mass movements. Geomorphology 30 (1-2), 33-52. \%U. 10.1016\%2Fs0169-555x\%2899\%2900043-4.

Leblanc, M., Favreau, G., Maley, J., Nazoumou, Y., Leduc, C., Stagnitti, F., Oevelen, P.J. V., Delclaux, F., Lemoalle, J., 2006. Reconstruction of megalake chad using shuttle radar topographic mission data. Palaeogeogr. Palaeoclimatol. Palaeoecol. 239 (1-2), 16-27. \%U. 10.1016\%2Fj.palaeo.2006.01.003.

Lee, C.F., Dai, F.C., 2011. The 1786 Dadu River Landslide Dam, Sichuan, China, Natural and Artificial Rockslide Dams. Springer, pp. 369-388.

Li, M.-H., Sung, R.-T., Dong, J.-J., Lee, C.-T., Chen, C.-C., 2011. The formation and breaching of a short-lived landslide dam at Hsiaolin Village, Taiwan-Part II: Simulation of debris flow with landslide dam breach. Eng. Geol. 123 (1-2), 60-71.

Liang, Y., Zeng, C., Wang, J.J., Liu, M.W., Yeh, T.C.J., Zha, Y.Y., 2017. Constant gradient erosion apparatus for appraisal of piping behavior in upward seepage flow. Geotech. Test. J. 40 (4), 20150282. \%U. 10.1520\%2Fgtj20150282.

Lin, P., Liu, X., Zhang, J., 2015. The simulation of a landslide-induced surge wave and its overtopping of a dam using a coupled ISPH model. Eng. Appl. Comput. Fluid Mech. 9 (1), 432-444.

Liu, N., Zhang, J., Lin, W., Cheng, W., Chen, Z., 2009. Draining Tangjiashan Barrier Lake after Wenchuan Earthquake and the flood propagation after the dam break. Science in China Series E: Technological Sciences 52 (4), 801-809.

Liu, F., Fu, X., Wang, G., Duan, J., 2012. Physically based simulation of dam breach development for Tangjiashan Quake Dam, China. Environ. Earth Sci. 65 (4), 1081-1094.
Liu, C., Pollard, D.D., Shi, B., 2013. Analytical solutions and numerical tests of elastic and failure behaviors of close-packed lattice for brittle rocks and crystals. J. Geophys. Res. Solid Earth 118 (1), 71-82.

Liu, Y., Wang, X., Wu, Z., He, Z., Yang, Q., 2018. Simulation of landslide-induced surges and analysis of impact on dam based on stability evaluation of reservoir bank slope. Landslides 15 (10), 2031-2045.

Lo, C.-M., Lin, M.-L., Tang, C.-L., Hu, J.-C., 2011. A kinematic model of the Hsiaolin landslide calibrated to the morphology of the landslide deposit. Eng. Geol. 123 (1-2), 22-39.

Loke, M.H., Chambers, J.E., Rucker, D.F., Kuras, O., Wilkinson, P.B., 2013. Recent developments in the direct-current geoelectrical imaging method. J. Appl. Geophys. 95, 135-156.

Lucieer, A., Jong, S.M.d., Turner, D., 2014. Mapping landslide displacements using Structure from Motion (SfM) and image correlation of multi-temporal UAV photography. Prog. Phys. Geogr. 38 (1), 97-116.

Lumbroso, D., Davison, M., Body, R., Petkovšek, G., 2020. Modelling the Brumadinho tailings dam failure, the subsequent loss of life and how it could have been reduced. Natural Hazards and Earth System Sciences Discussions 1-24.

Macchione, F., Sirangelo, B., 1988. Study of Earth Dam Erosion Due to Overtopping.

Manville, V., 2001. Techniques for Evaluating the Size of Potential Dam-Break Floods from Natural Dams. Institute of Geological \& Nuclear Sciences.

Marot, D., Rochim, A., Nguyen, H.-H., Bendahmane, F., Sibille, L., 2016. Assessing the susceptibility of gap-graded soils to internal erosion: proposition of a new experimental methodology. Nat. Hazards 83 (1), 365-388. \%U. 10.1007\%2Fs110 69-016-2319-8.

Massey, C.I., Townsend, D.B., Dellow, G.D., Lukovic, B., Rosser, B.J., Archibald, G.C. Villeneuve, M., Davidson, J., Jones, K.E., Morgenstern, R., et al., 2018. Kaikoura Earthquake Short-Term Project: landslide inventory and landslide dam assessments. GNS Science, Lower Hutt (NZ), p. 45.

Massonnet, D., Feigl, K.L., 1998. Radar interferometry and its application to changes in the Earth's surface. Rev. Geophys. 36 (4), 441-500.

McCann, D., Forster, A., 1990. Reconnaissance geophysical methods in landslide investigations. Eng. Geol. 29 (1), 59-78.

McFeeters, S.K., 1996. The use of the Normalized Difference Water Index (NDWI) in the delineation of open water features. Int. J. Remote Sens. 17 (7), 1425-1432. \%U. 10 $.1080 \% 2 \mathrm{~F} 01431169608948714$.

Meric, O., Garambois, S., Jongmans, D., Wathelet, M., Chatelain, J.-L., Vengeon, J.M., 2005. Application of geophysical methods for the investigation of the large gravitational mass movement of Séchilienne, France. Can. Geotech. J. 42 (4), 1105-1115.

Meyer, W., Sabol, M.A., Glicken, H.X., Voight, B., 1985. The effects of ground water, slope stability, and seismic hazards on the stability of the South Fork Castle Creek blockage in the Mount St. Helens area, Washington., pp. 2330-7102.

Miller, B., Dufresne, A., Geertsema, M., Atkinson, N., Evensen, H., Cruden, D., 2018. Longevity of dams from landslides with sub-channel rupture surfaces, Peace River region, Canada. Geoenviron. Disast. 5 (1), 1.

Moffat, R., Fannin, R.J., 2011. A hydromechanical relation governing internal stability of cohesionless soil. Can. Geotech. J. 48 (3), 413-424.

Moffat, R., Fannin, R.J., Garner, S.J., 2011. Spatial and temporal progression of internal erosion in cohesionless soil. Can. Geotech. J. 48 (3), 399-412.

Morche, D., Schmidt, K.H., 2012. Sediment transport in an alpine river before and after a dambreak flood event. Earth Surf. Process. Landf. 37 (3), 347-353.

Moreiras, S.M., Hermanns, R.L., Fauqué, L., 2015. Cosmogenic dating of rock avalanches constraining Quaternary stratigraphy and regional neotectonics in the Argentine Central Andes (32 S). Quat. Sci. Rev. 112, 45-58.

Morris, M.W., 2013. Breaching of earth embankments and dams.

Morris, M., West, M., Hassan, M., 2018. A guide to breach prediction. Dams Reserv. 28 (4), 150-152.

Morris, M., Hassan, M., Goff, C., 2020. EMBREA-Web: a tool for the simulation of breach through dams and embankments.

Nadal-Romero, E., Verachtert, E., Maes, R., Poesen, J., 2011. Quantitative assessment of the piping erosion susceptibility of loess-derived soil horizons using the pinhole test. Geomorphology 135 (1-2), 66-79. \%U. 10.1016\%2Fj.geomorph.2011.07.026.

Nian, T.-K., Wu, H., Takara, K., Li, D.-Y., Zhang, Y.-J., 2021. Numerical investigation on the evolution of landslide-induced river blocking using coupled DEM-CFD. Comput. Geotech. 134, 104101.

Niazi, F.S., Habib Ur, R., Akram, T., 2010. Application of electrical resistivity for subsurface characterization of Hattian Bala landslide dam, GeoFlorida 2010. Adv. Analysis Model. Desig. 480-489.

Nicolussi, K., Spötl, C., Thurner, A., Reimer, P.J., 2015. Precise radiocarbon dating of the giant Köfels landslide (Eastern Alps, Austria). Geomorphology 243, 87-91. \%U. 10 .1016\%2Fj.geomorph.2015.05.001.

Nikonov, A.A., Shebalina, T.Y., 1979. Lichenometry and earthquake age determination in central Asia. Nature 280 (5724), 675-677. \%U. 10.1038\%2F280675a0.

Okada, H., Suto, K., 2003. The Microtremor Survey Method. Society of Exploration Geophysicists.

Okeke, A.C.-U., Wang, F., 2016a. Hydromechanical constraints on piping failure of landslide dams: an experimental investigation. Geoenviron. Disast. 3 (1 \%U doi 10.1186\%2Fs40677-016-0038-9).

Okeke, A.C.-U., Wang, F., 2016b. Critical hydraulic gradients for seepage-induced failure of landslide dams. Geoenviron. Disast. 3 (1 \%U doi:10.1186\%2Fs40677-016-0043z).

Okeke, A.C.-U., Wang, F., Kuwada, Y., Mitani, Y., 2017. Experimental Study of the Premonitory Factors for Internal Erosion and Piping Failure of Landslide Dams, Advancing Culture of Living with Landslides. Springer International Publishing, pp. 389-397. \%U. 10.1007\%2F978-3-319-53498-5_45. 
Olhoeft, G.R., 2002. Applications and frustrations in using ground penetrating radar. IEEE Aerosp. Electron. Syst. Mag. 17 (2), 12-20.

Oppikofer, T., Böhme, M., Nicolet, P., Penna, I.M., Hermanns, R.L., 2016a. Metodikk for konsekvensanalyse av fjellskred. Geol. Surv. Norw., Trondheim, Norway, NGU report, 67.

Oppikofer, T., Hermanns, R.L., Sandøy, G., Böhme, M., Jaboyedoff, M., Horton, P. Roberts, N.J., Fuchs, H., 2016b. Quantification of casualties from potential rockslope failures in Norway. Landslides and Engineered Slopes. Experience, Theory and Practice, edited by: Aversa, S., Cascini, L., Picarelli, L., and Scavia, C., Associazione Geotecnica Italiana, Rome, Italy, pp. 1537-1544.

Oppikofer, T., Hermanns, R.L., Roberts, N.J., Böhme, M., 2019. SPLASH: semi-empirical prediction of landslide-generated displacement wave run-up heights. Geol. Soc. Lond., Spec. Publ. 477 (1), 353-366.

Oppikofer, T., Hermanns, R.L., Jakobsen, V.U., Böhme, M., Nicolet, P., Penna, I., 2020. Forecasting dam height and stability of dams formed by rock slope failures in Norway. Natural Hazards and Earth System Sciences Discussions 2020, 1-24.

Ostermann, M., Sanders, D., 2017. The Benner pass rock avalanche cluster suggests a close relation between long-term slope deformation (DSGSDs and translational rock slides) and catastrophic failure. Geomorphology 289, 44-59.

Ostermann, M., Ivy-Ochs, S., Sanders, D., Prager, C., 2017. Multi-method (14C, 36Cl, 234U/230Th) age bracketing of the Tschirgant rock avalanche (Eastern Alps): implications for absolute dating of catastrophic mass-wasting. Earth Surf. Process. Landf. 42 (7), 1110-1118.

Ouyang, C., He, S., Xu, Q., Luo, Y., Zhang, W., 2013. A MacCormack-TVD finite difference method to simulate the mass flow in mountainous terrain with variable computational domain. Comput. Geosci. 52, 1-10.

Ouyang, C., He, S., Xu, Q., 2014. MacCormack-TVD finite difference solution for dam break hydraulics over erodible sediment beds. J. Hydraul. Eng. 141 (5), 06014026.

Pánek, T., 2015. Recent progress in landslide dating: a global overview. Prog. Phys. Geogr. 39 (2), 168-198.

Pánek, T., Hradeckỳ, J., Minár, J., Hungr, O., Dušek, R., 2009. Late Holocene catastrophic slope collapse affected by deep-seated gravitational deformation in flysch: Ropice Mountain, Czech Republic. Geomorphology 103 (3), 414-429.

Pánek, T., Smolková, V., Hradeckỳ, J., Baroñ, I., Šilhán, K., 2013. Holocene reactivations of catastrophic complex flow-like landslides in the Flysch Carpathians (Czech Republic/Slovakia). Quat. Res. 80 (1), 33-46.

Papyrin, L.P., 2001. Sarezskaya katastrofa: geofizichesky prognoz.(The Sarez catastrophe: geophysical forecast). Geofizika XXI Stoletiya: 183e194.

Park, C.B., Miller, R.D., Xia, J., 1999. Multichannel analysis of surface waves. Geophysics 64 (3), 800-808.

Parvaiz, I., Champatiray, P.K., Bhat, F.A., Dadhwal, V.K., 2012. Earthquake-induced landslide dam in the Kashmir Himalayas. Int. J. Remote Sens. 33 (2), 655-660.

Patella, D., 1997. Self-potential global tomography including topographic effects. Geophys. Prospect. 45 (5), 843-863.

Patzelt, G., 2012. Die Bergstürze von Tschirgant und von Haiming, Oberinntal, Tirol-Begleitworte zur Kartenbeilage. Jahrb. Geol. Bundesanst. 152 (1-4), 13-24.

Peakall, J., Ashworth, P., Best, J., 1996. Physical modelling in fluvial geomorphology: principles, applications and unresolved issues. Scient. Nat. Geomorphol. 221-253.

Peng, S.-H., 2012. 1D and 2D numerical modeling for solving dam-break flow problems using finite volume method. J. Appl. Math. 2012.

Peng, M., Zhang, L.M., 2012a. Analysis of human risks due to dam break floods-part 2. application to Tangjiashan landslide dam failure. Nat. Hazards 64 (2), 1899-1923.

Peng, M., Zhang, L.M., 2012b. Breaching parameters of landslide dams. Landslides 9 (1), 13-31.

Peng, M., Zhang, L.M., 2012c. Analysis of human risks due to dam break floods-part 2: application to Tangjiashan landslide dam failure. Nat. Hazards 64 (2), 1899-1923.

Peng, M., Zhang, L.M., Chang, D.S., Shi, Z.M., 2014. Engineering risk mitigation measures for the landslide dams induced by the 2008 Wenchuan earthquake. Eng. Geol. 180, 68-84.

Penna, I.M., Hermanns, R.L., Folguera, A., 2008. Remoción en masa y colapso catastrófico de diques naturales generados en el frente orogénico andino $\left(36^{\circ}-38^{\circ} \mathrm{s}\right)$ : los casos Navarrete y Río Barrancas. Rev. Asoc. Geol. Argent. 63 (2), 172-180.

Penna, I.M., Hermanns, R.L., Niedermann, S., Folguera, A., 2011. Multiple slope failures associated with neotectonic activity in the Southern Central Andes (37-37 30' S), Patagonia, Argentina. Bulletin 123 (9-10), 1880-1895.

Perrone, A., Lapenna, V., Piscitelli, S., 2014. Electrical resistivity tomography technique for landslide investigation: a review. Earth Sci. Rev. 135, 65-82.

Pesci, A., Teza, G., Casula, G., Loddo, F., De Martino, P., Dolce, M., Obrizzo, F., Pingue, F., 2011. Multitemporal laser scanner-based observation of the Mt. Vesuvius crater: Characterization of overall geometry and recognition of landslide events. ISPRS J. Photogramm. Remote Sens. 66 (3), 327-336.

Peternel, T., Kumelj, Š., Oštir, K., Komac, M., 2017. Monitoring the Potoška planina landslide (NW Slovenia) using UAV photogrammetry and tachymetric measurements. Landslides 14 (1), 395-406.

Plaza, G., Zevallos, O., Cadier, É., 2011. La Josefina Landslide Dam and Its Catastrophic Breaching in the Andean Region of Ecuador, Natural and artificial rockslide dams. Springer, pp. 389-406.

Plaza-Nieto, G., Zevallos, O., 1994. The 1993 La Josefina rockslide and Rio Paute landslide dam, Ecuador. Landslide News 8, 4-6.

Prager, C., Ivy-Ochs, S., Ostermann, M., Synal, H.A., Patzelt, G., 2009. Geology and radiometric 14C-, $36 \mathrm{Cl}$-and Th-/U-dating of the Fernpass rockslide (Tyrol, Austria). Geomorphology 103 (1), 93-103.

Preusser, F., Degering, D., Fuchs, M., Hilgers, A., Kadereit, A., Klasen, N., Krbetschek, M., Richter, D., Spencer, J.Q.G., 2008. Luminescence dating: basics, methods and applications. Eiszeitalter \& Ggenwart= Quat. Sci. J. 57 (1/2), 95-149.
Raspini, F., Bardi, F., Bianchini, S., Ciampalini, A., Del Ventisette, C., Farina, P., Ferrigno, F., Solari, L., Casagli, N., 2017. The contribution of satellite SAR-derived displacement measurements in landslide risk management practices. Nat. Hazards 86 (1), 327-351.

Redpath, B.B., 1973. Seismic refraction exploration for engineering site investigations. Army Engineer Waterways Experiment Station, Livermore, Calif.(USA).

Regmi, R.K., Nakagawa, H., Kawaike, K., Baba, Y., Zhang, H., 2010. Two and three dimensional slope stability analysis of landslide dam failure due to sliding.

Regmi, R.K., Lee, G., Jung, K., 2013. Analysis on failure of slope and landslide dam. KSCE J. Civ. Eng. 17 (5), 1166-1178.

Reneau, S.L., Dethier, D.P., 1996. Late Pleistocene landslide-dammed lakes along the Rio Grande, White Rock Canyon, New Mexico. Geol. Soc. Am. Bull. 108 (11), 1492-1507.

Richards, K.S., Reddy, K.R., 2010. True triaxial piping test apparatus for evaluation of piping potential in earth structures. Geotech. Test. J. 33 (1), 83-95.

Rickenmann, D., 2005. Runout prediction methods, Debris-flow hazards and related phenomena. Springer, pp. 305-324.

Rifai, I., Erpicum, S., Archambeau, P., Violeau, D., Pirotton, M., Abderrezzak, K.E.K., Dewals, B., 2017. Overtopping induced failure of noncohesive, homogeneous fluvial dikes. Water Resour. Res. 53 (4), 3373-3386. \%U. 10.1002\%2F2016wr020053.

Ríha, J., Kotaška, S., Petrula, L., 2020. Dam Break Modeling in a Cascade of Small Earthen Dams: Case Study of the Čižina River in the Czech Republic. Water 12 (8), 2309.

Risley, J.C., Walder, J.S., Denlinger, R.P., 2006. Usoi dam wave overtopping and flood routing in the Bartang and Panj Rivers, Tajikistan. Nat. Hazards 38 (3), 375-390.

Rochim, A., Marot, D., Sibille, L., Le, V.T., 2017. Effects of hydraulic loading history on suffusion susceptibility of cohesionless soils. J. Geotech. Geoenviron. 143 (7), 04017025. \%U. 10.1061\%2F\%28asce\%29gt.1943-5606.0001673.

Rossi, G., Tanteri, L., Tofani, V., Vannocci, P., Moretti, S., Casagli, N., 2018. Multitemporal UAV surveys for landslide mapping and characterization. Landslides 15 (5), 1045-1052.

Rott, H., Siegel, A., 1999. Analysis of mass movements in alpine terrain by means of SAR interferometry. In: IEEE 1999 International Geoscience and Remote Sensing Symposium. IGARSS'99 (Cat. No. 99CH36293). IEEE, pp. 1933-1936.

Safran, E.B., O'Connor, J.E., Ely, L.L., House, P.K., Grant, G., Harrity, K., Croall, K., Jones, E., 2015. Plugs or flood-makers? The unstable landslide dams of eastern Oregon. Geomorphology 248, 237-251.

Sandrp, 2018. Landslide DAM on Tsangpo creates flood disaster risk for Siang.

Sanhueza-Pino, K., Korup, O., Hetzel, R., Munack, H., Weidinger, J.T., Dunning, S., Ormukov, C., Kubik, P.W., 2011. Glacial advances constrained by 10 Be exposure dating of bedrock landslides, Kyrgyz Tien Shan. Quat. Res. 76 (3), 295-304.

Santamarina, J.C., Rinaldi, V.A., Fratta, D., Klein, K.A., Wang, Y.-H., Cho, G.C., Cascante, G., 2005. A survey of elastic and electromagnetic properties of nearsurface soils. Near-Surf. Geophys. 1, 71-87.

Sassa, K., Nagai, O., Solidum, R., Yamazaki, Y., Ohta, H., 2010. An integrated model simulating the initiation and motion of earthquake and rain induced rapid landslides and its application to the 2006 Leyte landslide. Landslides 7 (3), 219-236.

Satofuka, Y., Mori, T., Mizuyama, T., Ogawa, K., Yoshino, K., 2010. Prediction of floods caused by landslide dam collapse. J. Disast. Res. 5 (3), 288-295.

Scaioni, M., Longoni, L., Melillo, V., Papini, M., 2014. Remote sensing for landslide investigations: an overview of recent achievements and perspectives. Remote Sens. 6 (10), 9600-9652.

Schleier, M., Hermanns, R.L., Rohn, J., Gosse, J.C., 2015. Diagnostic characteristics and paleodynamics of supraglacial rock avalanches, Innerdalen, Western Norway. Geomorphology 245, 23-39.

Schleier, M., Hermanns, R.L., Gosse, J.C., Oppikofer, T., Rohn, J., Tønnesen, J.F., 2017. Subaqueous rock-avalanche deposits exposed by post-glacial isostatic rebound, Innfjorddalen, Western Norway. Geomorphology 289, 117-133.

Schmocker, L., Hager, W.H., 2009. Modelling dike breaching due to overtopping. J. Hydraul. Res. 47 (5), 585-597.

Schmocker, L., Hager, W.H., 2012. Plane dike-breach due to overtopping: effects of sediment, dike height and discharge. J. Hydraul. Res. 50 (6), 576-586.

Schuster, R.L., 1986. Landslide Dams: Processes, Risk, and Mitigation. ASCE.

Schuster, R.L., 1995. Landslide dams - a worldwide phenomenon. J Jpn Landslide Soc 31 (4), 38-49.

Schuster, R.L., Evans, S.G., 2011. Engineering measures for the hazard reduction of landslide dams, Natural and Artificial Rockslide Dams. Springer, pp. 77-100.

Schuster, R.L., Logan, R.L., Pringle, P.T., 1992. Prehistoric rock avalanches in the Olympic Mountains, Washington. Science 258 (5088), 1620-1621.

Shen, D., Shi, Z., Peng, M., Zhang, L., Jiang, M., 2020. Longevity analysis of landslide dams. Landslides 17 (8), 1797-1821.

Shi, Z.M., Guan, S.G., Peng, M., Zhang, L.M., Zhu, Y., Cai, Q.P., 2015. Cascading breaching of the Tangjiashan landslide dam and two smaller downstream landslide dams. Eng. Geol. 193, 445-458.

Shroder Jr., J.F., Weihs, B.J., 2010. Geomorphology of the Lake Shewa Landslide Dam, Badakhshan, Afghanistan, using remote sensing data. Geografiska Annaler: Series A, Physical Geography 92 (4), 469-483.

Simmler, H., Samet, L., 1982. Dam failure from overtopping studied on a hydraulic model. ICOLD, Fourteenth Congress, pp. 427-445.

Singh, V.P., 2013. Dam Breach Modeling Technology, 17. Springer Science \& Business Media.

Singleton, A., Li, Z., Hoey, T., Muller, J.P., 2014. Evaluating sub-pixel offset techniques as an alternative to D-InSAR for monitoring episodic landslide movements in vegetated terrain. Remote Sens. Environ. 147, 133-144.

Sivakumar Babu, G.L., Vasudevan, A.K., 2008. Seepage velocity and piping resistance of coir fiber mixed soils. J. Irrig. Drain. Eng. 134 (4), 485-492. 
Smith, W.D., Dunning, S.A., Brough, S., Ross, N., Telling, J., 2020. GERALDINE (Google Earth Engine supRaglAciaL Debris INput dEtector): a new tool for identifying and monitoring supraglacial landslide inputs. Earth Surf. Dynam. 8 (4), 1053-1065.

Stokoe, K.H., Wright, S.G., Bay, J.A., Roesset, J.M., 1994. Characterization of geotechnical sites by SASW method, Special Volume of ISSMFE TC10, pp. 15-25.

Strangway, D.W., 1983. Audiofrequency magnetotelluric (AMT) sounding. Dev. Geophys. Explor. Methods 5, 107.

Strangway, D.W., Swift, C.M., Holmer, R.C., 1973. The application of audio-frequency magnetotellurics (AMT) to mineral exploration. Geophysics 38 (6), 1159-1175.

Strom, A.L., 1996. Some morphological types of long-runout rockslides: effect of the relief on their mechanism and on the rockslide deposits distribution. Landslides 1977-1982.

Strom, A., 2006. Morphology and internal structure of rockslides and rock avalanches: grounds and constraints for their modelling, Landslides from Massive Rock Slope Failure. Springer, pp. 305-326.

Strom, A., 2010. Landslide dams in Central Asia region. J. Jpn Landslide Soc. 47 (6), 309-324.

Strom, A., 2014. Sarez lake problem: ensuring long-term safety, Landslide Science for a Safer Geoenvironment. Springer, pp. 633-639.

Strom, A., Abdrakhmatov, K., 2018. Rockslides and rock avalanches of Central Asia: distribution, morphology, and internal structure. Elsevier.

Strom, A.L., Korup, O., 2006. Extremely large rockslides and rock avalanches in the Tien Shan Mountains, Kyrgyzstan. Landslides 3 (2), 125-136.

Sun, L., Muller, J.-P., 2016. Evaluation of the use of sub-pixel offset tracking techniques to monitor landslides in densely vegetated steeply sloped areas. Remote Sens. 8 (8), 659.

Sun, R., Wang, X., Zhou, Z., Ao, X., Sun, X., Song, M., 2014. Study of the comprehensive risk analysis of dam-break flooding based on the numerical simulation of flood routing. Part I: model development. Nat. Hazards 73 (3), 1547-1568.

Tabata, S., 2001. Study on prediction of peak discharge in floods caused by landslide dam failures. J. Eros. Control Eng. 54 (4), 73-76.

Tacconi Stefanelli, C., Catani, F., Casagli, N., 2015. Geomorphological investigations on landslide dams. Geoenviron. Disast. 2 (1), 21.

Tacconi Stefanelli, Carlo, Segoni, Samuele, Casagli, Nicola, Catani, Filippo, 2016. Geomorphic indexing of landslide dams evolution. Engineering Geology 208, 1-10. https://doi.org/10.1016/j.enggeo.2016.04.024.

Tacconi Stefanelli, C., Vilímek, V., Emmer, A., Catani, F., 2018. Morphological analysis and features of the landslide dams in the Cordillera Blanca, Peru. Landslides 15 (3), 507-521.

Tachikawa, T., Kaku, M., Iwasaki, A., 2011. Aster GDEM version 2 validation report. Report to the ASTER GDEM Version 2.

Takahashi, T., 1988. Hydrograph prediction of debris flow due to failure of landslide dam. Annual Reports of Disaster Prevention Research Institute, Kyoto University 31 (2), 601-615.

Takahashi, T., Nakagawa, H., Harada, T., Yamashiki, Y., 1992. Routing debris flows with particle segregation. J. Hydraul. Eng. 118 (11), 1490-1507.

Tezkan, B., 1999. A review of environmental applications of quasi-stationary electromagnetic techniques. Surv. Geophys. 20 (3-4), 279-308.

Thouret, J.-C., Gunnell, Y., Jicha, B.R., Paquette, J.-L., Braucher, R., 2017. Canyon incision chronology based on ignimbrite stratigraphy and cut-and-fill sediment sequences in SW Peru documents intermittent uplift of the western Central Andes. Geomorphology 298, 1-19. \%U. 10.1016\%2Fj.geomorph.2017.09.013.

Tofani, V., Catani, F., Casagli, N., 2010. Weather Forecasting and Radar Technologies for Landslide Prediction and Mapping: Some Examples in Italy. na.

Tomlinson, S.S., Vaid, Y.P., 2000. Seepage forces and confining pressure effects on piping erosion. Can. Geotech. J. 37 (1), 1-13. \%U. 10.1139\%2Ft99-116.

Torgoev, A., Lamair, L., Torgoev, I., Havenith, H.-B., 2013. A Review of Recent Case Studies of Landslides Investigated in the Tien Shan Using Microseismic and Other Geophysical Methods. Springer, Berlin Heidelberg, pp. 285-294.

Torgoev, I.A., Havenith, H.-B., Torgoev, A.D., 2014. Geophysical Monitoring of Artificial Landslide Dam of Kambarata Hydro Power Plant-2 (Kyrgyzstan), Landslide Science for a Safer Geoenvironment. Springer, pp. 641-647.

Trauth, M.H., Strecker, M.R., 1999. Formation of landslide-dammed lakes during a wet period between 40,000 and 25,000 yr B.P. in northwestern Argentina. Palaeogeogr. Palaeoclimatol. Palaeoecol. 153 (1-4), 277-287. \%U. 10.1016\%2Fs0031-0182\%28 99\%2900078-4.

Trauth, M.H., Alonso, R.A., Haselton, K.R., Hermanns, R.L., Strecker, M.R., 2000. Climate change and mass movements in the NW Argentine Andes. Earth Planet. Sci. Lett. 179 (2), 243-256.

Trauth, M.H., Deino, A., Strecker, M.R., 2001. Response of the East African climate to orbital forcing during the last interglacial (130-117 ka) and the early last glacial (117-60 ka). Geology 29 (6), 499-502.

Tsou, C.-Y., Feng, Z.-Y., Chigira, M., 2011. Catastrophic landslide induced by typhoon Morakot, Shiaolin, Taiwan. Geomorphology 127 (3-4), 166-178.

Van Asch, T.W.J., Tang, C., Alkema, D., Zhu, J., Zhou, W., 2014. An integrated model to assess critical rainfall thresholds for run-out distances of debris flows. Nat. Hazards 70 (1), 299-311.

Van Der Knijff, J.M., Younis, J., De Roo, A.P.J., 2010. LISFLOOD: a GIS-based distributed model for river basin scale water balance and flood simulation. Int. J. Geogr. Inf. Sci. 24 (2), 189-212.

Van Tien, P., Sassa, K., Takara, K., Fukuoka, H., Dang, K., Shibasaki, T., Ha, N.D., Setiawan, H., Loi, D.H., 2018. Formation process of two massive dams following rainfall-induced deep-seated rapid landslide failures in the Kii Peninsula of Japan. Landslides 15 (9), 1761-1778.

Varnes, D.J., 1978. Slope movement types and processes. Spec. Rep. 176, 11-33.
Wahl, T.L., 1997. Predicting embankment dam breach parameters-A needs assessment, Proceedings of the Congress-International Association for Hydraulic Research. Local Organizing Committee of the XXV Congress, pp. 48-53.

Wahl, T.L., 2004. Uncertainty of predictions of embankment dam breach parameters. J. Hydraul. Eng. 130 (5), 389-397.

Walder, J.S., O'Connor, J.E., 1997. Methods for predicting peak discharge of floods caused by failure of natural and constructed earthen dams. Water Resour. Res. 33 (10), 2337-2348.

Walder, J.S., Iverson, R.M., Godt, J.W., Logan, M., Solovitz, S.A., 2015. Controls on the breach geometry and flood hydrograph during overtopping of noncohesive earthen dams. Water Resour. Res. 51 (8), 6701-6724.

Walker, M., 2005. Quaternary Dating Methods. John Wiley and Sons.

Wallace, L., Lucieer, A., Watson, C., Turner, D., 2012. Development of a UAV-LiDAR system with application to forest inventory. Remote Sens. 4 (6), 1519-1543.

Walter, F., Amann, F., Kos, A., Kenner, R., Phillips, M., Preux, A.D., Huss, M., Tognacca, C., Clinton, J., Diehl, T., Bonanomi, Y., 2020. Direct observations of a three million cubic meter rock-slope collapse with almost immediate initiation of ensuing debris flows. Geomorphology 351, 106933. \%U. 10.1016\%2Fj.ge omorph.2019.106933.

Wan, C.F., Fell, R., 2004. Laboratory tests on the rate of piping erosion of soils in embankment dams. Geotech. Test. J. 27 (3), 295-303.

Wang, Z., 2008. A thunder at the beginning of the 21st century - the giant Yigong landslide. Landslides Eng. Slopes 2, 2111-2118.

Wang, G., Huang, R., Kamai, T., Zhang, F., 2013. The internal structure of a rockslide dam induced by the 2008 Wenchuan (Mw7. 9) earthquake, China. Eng. Geol. 156, $28-36$.

Wang, G., Huang, R., Lourenço, S.D., Kamai, T., 2014a. A large landslide triggered by the 2008 Wenchuan (M8. 0) earthquake in Donghekou area: Phenomena and mechanisms. Eng. Geol. 182, 148-157.

Wang, Y., Han, B., Wu, J., Chen, Y., Zhou, Y., Jiang, F., 2014b. The evolution of the Zhanggu landslide. Project Planning and Project Success: The 25\% Solution: 129.

Wang, B., Zhang, T., Zhou, Q., Wu, C., Chen, Y.-1., Wu, P., 2015. A case study of the Tangjiashan landslide dam-break. J. Hydrodyn. 27 (2), 223-233.

Wang, G., Furuya, G., Zhang, F., Doi, I., Watanabe, N., Wakai, A., Marui, H., 2016a. Layered internal structure and breaching risk assessment of the Higashi-Takezawa landslide dam in Niigata, Japan. Geomorphology 267, 48-58.

Wang, L., Chen, Z., Wang, N., Sun, P., Yu, S., Li, S., Du, X., 2016b. Modeling lateral enlargement in dam breaches using slope stability analysis based on circular slip mode. Eng. Geol. 209, 70-81.

Wang, S., Chen, J.-S., He, H.-Q., He, W.-Z., 2016c. Experimental study on piping in sandy gravel foundations considering effect of overlying clay. Water Sci. Eng. 9 (2), $165-171$.

Wang, W., Chen, G., Zhang, Y., Zheng, L., Zhang, H., 2017. Dynamic simulation of landslide dam behavior considering kinematic characteristics using a coupled DDASPH method. Eng. Anal. Bound. Elem. 80, 172-183.

Wang, F., Dai, Z., Okeke, C.A.U., Mitani, Y., Yang, H., 2018a. Experimental study to identify premonitory factors of landslide dam failures. Eng. Geol. 232, 123-134.

Wang, F., Okeke, A.C.-U., Kogure, T., Sakai, T., Hayashi, H., 2018b. Assessing the internal structure of landslide dams subject to possible piping erosion by means of microtremor chain array and self-potential surveys. Eng. Geol. 234, 11-26.

Wang, W., Yin, K., Chen, G., Chai, B., Han, Z., Zhou, J., 2019. Practical application of the coupled DDA-SPH method in dynamic modeling for the formation of landslide dam. Landslides 16 (5), 1021-1032.

Ward, S.N., Day, S., 2011. The 1963 landslide and flood at Vaiont Reservoir Italy. A tsunami ball simulation. Ital. J. Geosci. 130 (1), 16-26.

Wasowski, J., Bovenga, F., 2014. Investigating landslides and unstable slopes with satellite Multi Temporal Interferometry: Current issues and future perspectives. Eng. Geol. 174, 103-138.

Wassmer, P., Schneider, J.L., Pollet, N., Schmitter-Voirin, C., 2004. Effects of the internal structure of a rock-avalanche dam on the drainage mechanism of its impoundment, Flims sturzstrom and Ilanz paleo-lake, Swiss Alps. Geomorphology 61 (1-2), 3-17.

Weidinger, J.T., 2011. Stability and life span of landslide dams in the Himalayas (India, Nepal) and the Qin Ling Mountains (China), Natural and Artificial Rockslide Dams. Springer, pp. 243-277.

Weidinger, J.T., Korup, O., Munack, H., Altenberger, U., Dunning, S.A., Tippelt, G., Lottermoser, W., 2014. Giant rockslides from the inside. Earth Planet. Sci. Lett. 389, 62-73.

Whiteley, J., Chambers, J., Uhlemann, S., Wilkinson, P., Kendall, J., 2019. Geophysical monitoring of moisture-induced landslides: a review. Rev. Geophys. 57 (1), $106-145$.

Whiteley, J., Chambers, J., Uhlemann, S., Boyd, J., Cimpoiasu, M., Holmes, J., Inauen, C., Watlet, A., Hawley-Sibbett, L., Sujitapan, C., 2020. Landslide monitoring using seismic refraction tomography-The importance of incorporating topographic variations. Eng. Geol. 268, 105525.

Xiong, X., Shi, Z.M., Guan, S.G., Zhang, F., 2018. Failure mechanism of unsaturated landslide dam under seepage loading - Model tests and corresponding numerical simulations. Soils Found. 58 (5), 1133-1152. \%U. 10.1016\%2Fj.sandf.2018.05.012.

Xu, Q., Fan, X.-M., Huang, R.-Q., Van Westen, C., 2009. Landslide dams triggered by the Wenchuan Earthquake, Sichuan Province, south west China. Bull. Eng. Geol. Environ. 68 (3), 373-386.

Xu, F., Zhou, H., Zhou, J., Yang, X., 2012. A mathematical model for forecasting the dambreak flood routing process of a landslide dam. Math. Probl. Eng. 2012.

Xu, H., Jiang, H., Yu, S., Yang, H., Chen, J., 2015. OSL and pollen concentrate 14C dating of dammed lake sediments at Maoxian, east Tibet, and implications for two historical earthquakes in AD 638 and 952. Quat. Int. 371, 290-299. \%U. 10.1016\%2Fj. quaint.2014.09.045. 
Yamada, R., Kariya, Y., Kimura, T., Sano, M., Li, Z., Nakatsuka, T., 2018. Age determination on a catastrophic rock avalanche using tree-ring oxygen isotope ratios - the scar of a historical gigantic earthquake in the Southern Alps, central Japan. Quat. Geochronol. 44, 47-54. \%U. 10.1016\%2Fj.quageo.2017.12.004.

Yamazaki, F., Matsuoka, M., 2007. Remote sensing technologies in post-disaster damage assessment. J. Earthquake Tsunami 1 (03), 193-210.

Yamazaki, D., Ikeshima, D., Neal, J.C., O'Loughlin, F., Sampson, C.C., Kanae, S., Bates, P. D., 2017. MERIT DEM: A new high-accuracy global digital elevation model and its merit to global hydrodynamic modeling. AGUFM 2017, H12C-04.

Yan, J., Cao, Z.-X., Liu, H.-H., Chen, L., 2009. Experimental study of landslide dam-break flood over erodible bed in open channels. J. Hydrodyn. 21 (1), 124-130.

Yang, K.-H., Wang, J.-Y., 2017. Experiment and statistical assessment on piping failures in soils with different gradations. Mar. Georesour. Geotechnol. 35 (4), 512-527.

Yarnold, J., Lombard, J., 1989. Litho-kinematic facies model for large landslide deposits in arid settings. AAPG (Am. Assoc. Pet. Geol.) Bull.; (United States) 73 (CONF8905132-).

Yi, C., Zhu, L., Seong, Y.B., Owen, L.A., Finkel, R.C., 2006. A lateglacial rock avalanche event, Tianchi Lake, Tien Shan, Xinjiang. Quat. Int. 154-155, 26-31. \%U. 10.1016\% 2Fj.quaint.2006.02.011.

Young, W.J., Warburton, J., 1996. Principles and practice of hydraulic modelling of braided gravel-bed rivers. J. Hydrol. N. Z. 175-198.

Yu, M.-H., Wei, H.-Y., Liang, Y.-J., Zhao, Y., 2013. Investigation of non-cohesive levee breach by overtopping flow. J. Hydrodyn. 25 (4), 572-579. \%U. 10.1016\%2Fs1001 $-6058 \% 2811 \% 2960398-4$.

Yunus, A.P., Avtar, R., Kraines, S., Yamamuro, M., Lindberg, F., Grimmond, C., 2016. Uncertainties in tidally adjusted estimates of sea level rise flooding (bathtub model) for the Greater London. Remote Sens. 8 (5), 366.
Yutao, F., Shengxie, X., 2009. Chain mechanism and optimized control of collapses, landslides and debris flows [J]. J. Catastrophol. 3.

Zhang, J., Li, Y., Xuan, G., Wang, X., Li, J., 2009a. Overtopping breaching of cohesive homogeneous earth dam with different cohesive strength. Sci. China Se. E: Technol. Sci. 52 (10), 3024-3029.

Zhang, L.M., Xu, Y., Jia, J.S., 2009b. Analysis of earth dam failures: a database approach. Georisk 3 (3), 184-189.

Zhang, L., Peng, M., Chang, D., Xu, Y., 2016. Dam Failure Mechanisms and Risk Assessment. John Wiley \& Sons.

Zhang, L., Xiao, T., He, J., Chen, C., 2019a. Erosion-based analysis of breaching of Baige landslide dams on the Jinsha River, China, in 2018. Landslides. 16, 1965-1979.

Zhang, Y., Huang, C.C., Shulmeister, J., Guo, Y., Liu, T., Kemp, J., Patton, N.R., Liu, L., Chen, Y., Zhou, Q., others, 2019b. Formation and evolution of the Holocene massive landslide-dammed lakes in the Jishixia Gorges along the upper Yellow River: No relation to China's Great Flood and the Xia Dynasty. Quat. Sci. Rev. 218, 267-280.

Zhao, T., Dai, F., Xu, N.-W., 2017. Coupled DEM-CFD investigation on the formation of landslide dams in narrow rivers. Landslides 14 (1), 189-201.

Yue, Z.-X., Cao, Z.-Y., Yan, J., 2008. Numerical modeling of breach of landslide dams [J]. Chin. J. Hydrodynam. 5.

Zhong, Q., Wang, L., Chen, S., Chen, Z., Shan, Y., Zhang, Q., Ren, Q., Mei, S., Jiang, J., Hu, L., Liu, J., 2021. Breaches of embankment and landslide dams - State of the art review. Earth Sci. Rev. 216, 103597.

Zhu, Y., Visser, P.J., Vrijling, J.K., Wang, G., 2011. Experimental investigation on breaching of embankments. Sci. China Technol. Sci. 54 (1), 148-155.

Zhu, J., Li, Y., Hu, Y., 2012. A virtual geographic environment for simulation analysis of dam-break flood routing. Trans Tech Publ. 926-931.

Zhu, X., Peng, J., Jiang, C., Guo, W., 2019. A preliminary study of the failure modes and process of landslide dams due to upstream flow. Water 11 (6), 1115. 